\title{
ALEXANDRE MARTINEWSKI
}

Controle termohigrométrico microambiental para roedores

de laboratório através da tecnologia termoelétrica:

montagem, avaliação de desempenho do

equipamento e teste de climatização

em ratos (Rattus norvegicus)
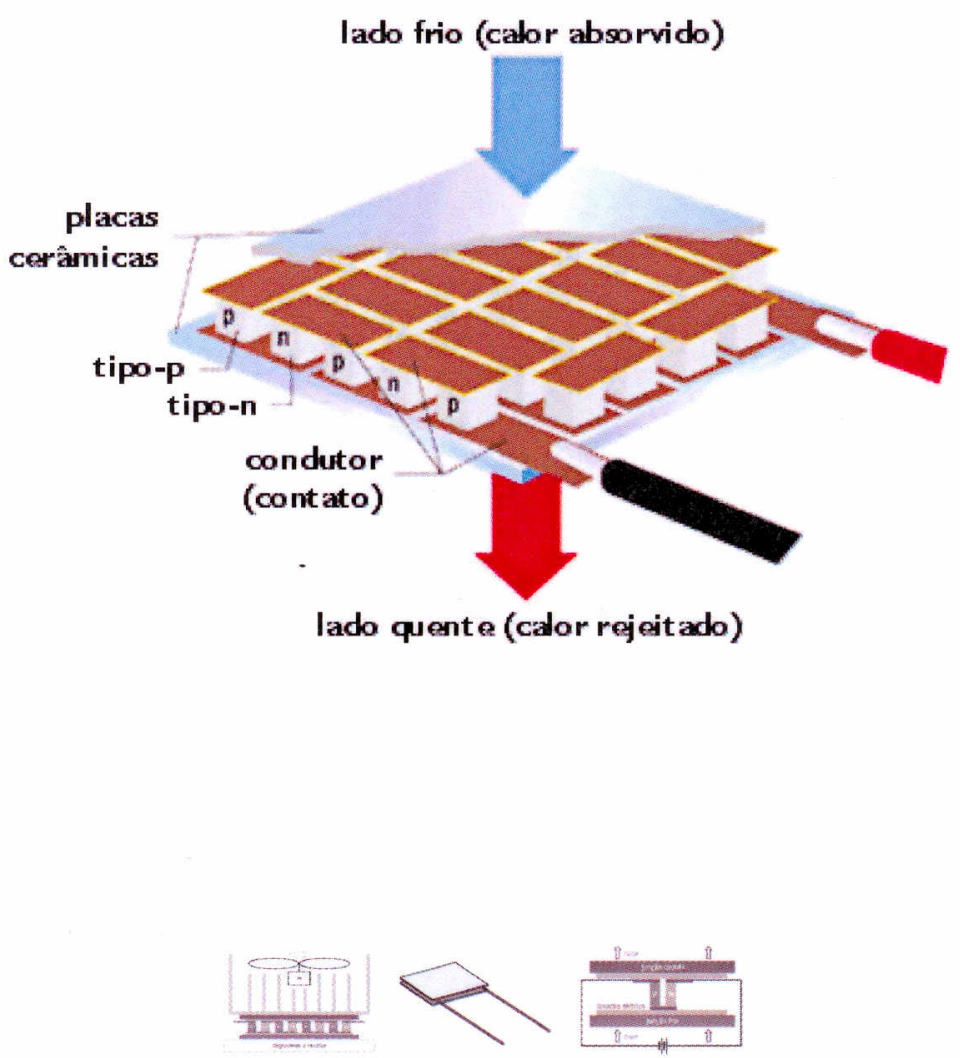

São Paulo

2007 


\section{ALEXANDRE MARTINEWSKI}

Controle termohigrométrico microambiental para roedores

de laboratório através da tecnologia termoelétrica:

montagem, avaliação de desempenho do

equipamento e teste de climatização

em ratos (Rattus norvegicus)

Tese apresentada ao Programa de PósGraduação em Patologia Experimental e Comparada da Faculdade de Medicina Veterinária e Zootecnia da Universidade de São Paulo para a obtenção do título de Doutor em Ciências

Departamento:

Patologia

Área de Concentração:

Patologia Experimental e Comparada

Orientador:

Prof. Dr. José Luiz Bernardino Merusse 
Autorizo a reprodução parcial ou total desta obra, para fins acadêmicos, desde que citada a fonte.

\section{DADOS INTERNACIONAIS DE CATALOGAÇÃO-NA-PUBLICAÇÃO}

(Biblioteca Virginie Buff D’Ápice da Faculdade de Medicina Veterinária e Zootecnia da Universidade de São Paulo)

Controle termohigrométrico microambiental para roedores de laboratório através da tecnologia termoelétrica: montagem, avaliação de desempenho do equipamento e teste de climatização em ratos (Rattus norvegicus) / Alexandre Martinewski. - São Paulo : A. Martinewski, 2007. $118 \mathrm{f}$. : il.

Tese (doutorado) - Universidade de São Paulo. Faculdade de Medicina Veterinária e Zootecnia. Departamento de Patologia, 2007.

Programa de Pós-Graduação: Patologia Experimental e Comparada.

Área de concentração: Patologia Experimental e Comparada.

Orientador: Prof. Dr. José Luiz Bernardino Merusse.

1. Animais de laboratório. 2. Módulos termoelétricos. 3. Temperatura. 4. Microambiente. I. Título. 


\section{UNIVERSIDADE DE SÃO PAULO \\ Faculdade de Medicina Veterinária e Zootecnia}

\section{Comissão Bioética \\ CERTIFICADO}

Certificamos que o Projeto intitulado "Controle termohigrométrico microambiental para roedores de laboratório através da tecnologia termoelétrica: montagem, avaliação de desempenho do equipamento e teste de climatização em ratos (Rattus norvegicus)", protocolo n³15/2003, utilizando 105 (cento e cinco) ratos, sob a responsabilidade do Prof. Dr. José Luiz Bernardino Merusse, está de acordo com os princípios éticos de experimentação animal da Comissão de Bioética da Faculdade de Medicina Veterinária e Zootecnia da Universidade de São Paulo e foi aprovado "ad referendum".

(We certify that the Research "Microenvironmental thermohygrometric control for laboratory rodents by means of thermoelectric technology: assembly, performance evaluation of equipment and acclimation in rats (Rattus norvegicus)" protocol number 315/2003, utilizing 105 (one hundred five) rats, under the responsibility of Prof. Dr. José Luiz Bernardino Merusse, indeterminate number of the swiss, agree with Ethical Principles in Animal Research adopted by Bioethic Commission of the Faculty of Veterinary Medicine and Zootechny of University of São Paulo and was approved "ad referendum").

São Paulo, 10 de julho de 2007

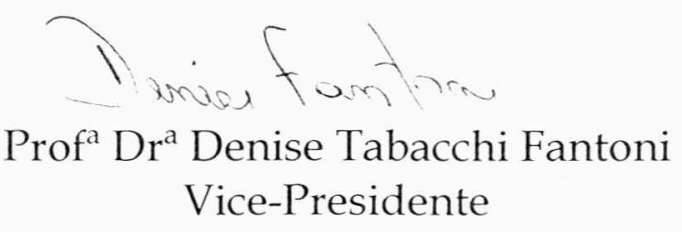

Av. Prof. Dr. Orlando Marques de Paiva, no 87 - 05508-270 - Cidade Universitária "Armando de Salles Oliveira". Fax: (11) 3032-2224 - fones: (11) 3091-7676/7671 - email: fmvz@edu.usp.br 


\section{FOLHA DE AVALIAÇÃO}

Nome: MARTINEWSKI, Alexandre

Título: Controle termohigrométrico microambiental para roedores de laboratório através da tecnologia termoelétrica: montagem, avaliação de desempenho do equipamento e teste de climatização em ratos (Rattus norvegicus)

Tese apresentada ao Programa de PósGraduação em Patologia Experimental e Comparada da Faculdade de Medicina Veterinária e Zootecnia da Universidade de São Paulo para a obtenção do título de Doutor em Ciências

Data:

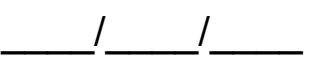

Banca Examinadora

Prof.(a) Dr.(a)

Assinatura

Prof.(a) Dr.(a)

Assinatura

Prof.(a) Dr.(a)

Assinatura

Prof.(a) Dr.(a)

Assinatura

Prof.(a) Dr.(a)

Assinatura Instituição: Julgamento: Instituição: Julgamento: Instituição: Julgamento: Instituição: Julgamento: Instituição: Julgamento: 


\section{À minha família, sempre presente.}

Aos meus eternos amigos.

Ao meu orientador, José Luiz Bernardino Merusse. 


\section{AGRADECIMENTOS}

À Professora Dra. Nívea Lopes de Souza, sempre presente para tirar qualquer dúvida.

A todos os funcionários e docentes, da Faculdade de Medicina Veterinária e Zootecnia da Universidade de São Paulo, que me acompanharam durante este período de trabalho.

Às amigas e funcionárias da Biblioteca Virginie Buff D’Apice da Faculdade de Medicina Veterinária e Zootecnia da Universidade de São Paulo que sempre se mostraram presentes e determinadas a ajudar.

A todos que estiveram comigo que, mesmo por um breve período de tempo, me tornaram uma pessoa mais feliz e confiante em meu trabalho.

À Fundação de Amparo a Pesquisa do Estado de São Paulo, pelo inestimável apoio financeiro a este projeto de Doutorado (Processo Nº2/09908-0). 


\section{RESUMO}

MARTINEWSKI, A. Controle termohigrométrico microambiental para roedores de laboratório através da tecnologia termoelétrica: montagem, avaliação de desempenho do equipamento e teste de climatização em ratos (Rattus norvegicus). [Microenvironmental thermohygrometric control for laboratory rodents by means of thermoelectric technology: assembly, performance evaluation of equipment and acclimation in rats (Rattus norvegicus)]. 2007. 118 f. Tese (Doutorado em Ciências) Faculdade de Medicina Veterinária e Zootecnia, Universidade de São Paulo, São Paulo, 2007.

Um condicionador de ar para biotérios foi montado com módulos termoelétricos de efeito Peltier. Para troca térmica, foram testados: 1. dissipação externa a ar, com $\Delta t$ de $14^{\circ} \mathrm{C}$, rendimento de $16,46 \%$, consumo de $1212 \mathrm{~W} / \mathrm{h}$ e, 2. dissipação externa água, com $\Delta \mathrm{t}$ de $21^{\circ} \mathrm{C}$, rendimento de $46,02 \%$, consumo de $524 \mathrm{~W} / \mathrm{h}$. A simulação matemática de operação, com mistura de ar não condicionado, mostrou que o sistema pode servir, na dissipação a ar, a aproximadamente 91 microisoladores padrão rato e a aproximadamente 137, na dissipação a água. Quando comparado com um sistema de compressão de freon, o termoelétrico mostrou economia de $26 \%$ na implantação e 38\% no consumo elétrico por BTU gerado. O sistema termoelétrico mostrou ainda, precisão de $\pm 0,1^{\circ} \mathrm{C}$, nas temperaturas experimentais, o que é impossível num sistema de freon. Para os testes em animais foram empregados Ratos wistar, mantidos individualmente, em gaiolas metabólicas de arame, sem abrigo, em sistema microambiental, sob fluxo direto de ar a 0,6 m/s, nas temperaturas de $22^{\circ}, 24^{\circ}, 26^{\circ}, 28^{\circ}$ e $30^{\circ} \mathrm{C}$ (E I, E II, E III, E IV e E V). A ingestão de ração e o ganho de peso foram comparados ao final de 5 dias (ANOVA; TukeyKramer). No total, 7 grupos de 15 animais cada foram comparados. Para a faixa de $22^{\circ} \mathrm{C}$ foram utilizados 3 grupos, sendo um grupo experimental e dois grupos controle (Cl e C II). Um deles foi mantido em condições ambientais semelhantes a biotérios convencionais sob ventilação geral diluidora (VGD) - C I. O outro grupo controle (C II) foi mantido no interior do equipamento de ventilação microambiental, porém, sem o direcionamento de ar, simulando a VGD. Os resultados obtidos demonstraram claramente que animais mantidos sob ventilação microambiental direta a $26^{\circ}, 28^{\circ} \mathrm{e}$ 
$30^{\circ}$ (E III, E IV e E V) apresentaram o mesmo ganho de massa corpórea que animais do grupo $\mathrm{C} \mathrm{I}\left(22 \pm 2^{\circ} \mathrm{C}\right)$. Os grupos $\mathrm{E}$ I e E II apresentaram menor ganho de massa corpórea quando comparados a C I ( $p<0,001$ em ambas comparações). $O$ ganho de peso de todos os grupos experimentais apresentou diferença estatística, quando comparado ao $\mathrm{C} I \mathrm{I}$, exceto o grupo $\mathrm{E} V$ que obteve índice de ganho de peso equivalente a C II. A ingestão de ração de todos os grupos se manteve praticamente constante. $\mathrm{O}$ grupo $\mathrm{E} \mathrm{V}$ apresentou uma redução na ingestão de ração quando comparado aos grupos C I, E I e E II ( $p<0,01 ; p<0,01 ; p<0,001$ respectivamente). $O$ grupo $E$ III ingeriu menos ração que os grupos $C$ I $(p<0,05)$ e $E$ II $(p<0,05)$.

Palavras-chave: Animais de laboratório. Módulos termoelétricos. Temperatura. Microambiente. 
ABSTRACT

MARTINEWSKI, A. Microenvironmental thermohygrometric control for laboratory rodents by means of thermoelectric technology: assembly, performance evaluation of equipment and acclimation in rats (Rattus norvegicus). [Controle termohigrométrico microambiental para roedores de laboratório através da tecnologia termoelétrica: montagem, avaliação de desempenho do equipamento e teste de climatização em ratos (Rattus norvegicus)]. 2007. 118 f. Tese (Doutorado em Ciências) - Faculdade de Medicina Veterinária e Zootecnia, Universidade de São Paulo, São Paulo, 2007.

An air-conditioner for animal facility was assembled with Peltier effect thermoelectric modules. For external exchanger, had been tested: 1. external air dissipation: $\Delta t=$ $14^{\circ} \mathrm{C} ; 16,46 \%$ of efficiency; $1212 \mathrm{~W} / \mathrm{h}$ of power consumption and, 2 . external water dissipation: $\Delta \mathrm{t}=21^{\circ} \mathrm{C} ; 46,02 \%$ of efficiency; $524 \mathrm{~W} / \mathrm{h}$ of power consumption. A mathematical simulation of operation, with not conditional air mixture, showed that the system can supply, with air dissipation, to $\cong 91$ microisolator rat cages and to $\cong$ 137 , with water dissipation. When compared with a freon system, the thermoelectric system shows economy of $26 \%$ in implantation and $38 \%$ in the electric consumption by generated BTU. The thermoelectric system showed too, a precision of $\pm 0,1^{\circ} \mathrm{C}$, at experimental temperatures, what is impossible in a freon system. For animal tests, Wistar rats had been kept individually, in metabolic wire cages, without shelter, in microenvironmental system, under direct air flow at $0,6 \mathrm{~m} / \mathrm{s}$, under temperatures of $22^{\circ}, 24^{\circ}, 26^{\circ}, 28^{\circ}$ and $30^{\circ} \mathrm{C}$ (E I, E II, E III, E IV and E V). The food ingestion and the weight gain had been compared in the end of 5 days (ANOVA; Tukey-Kramer). In the total, 7 groups, 15 animals each, had been compared. For the $22^{\circ} \mathrm{C}$ temperature, had been used 3 groups, one experimental and two controls (C I e C II). One of them was kept in similar ambient of conventional laboratory animal rooms conditions (general diluitory ventilation, GDV) - C I. The other control group (C II) was kept in the interior of the equipment of microenvironmental ventilation, however, without the direct air flow, simulating the GDV. The gotten results demonstrate clearly that animal kept under direct microenvironmental ventilation at $26^{\circ}, 28^{\circ}$ and $30^{\circ} \mathrm{C}$ (E III, E IV and E V) have the same gain of corporal mass that $\mathrm{C} I$ group $\left(22 \pm 2^{\circ} \mathrm{C}\right)$. The $\mathrm{E} I$ and $\mathrm{E} I \mathrm{I}$ had 
less corporal mass gain when compared to $C I$ ( $p<0,001$ for the two comparisons). The weight gain for all the experimental groups, when compared to $C$ II, presents statistical differences, except $E V$ group, that was equal to $C$ II. The food ingestion of all the groups was constant. The $\mathrm{E} V$ group presented a reduction in the food ingestion when compared with the groups C I, E I and E II $(p<0,01 ; p<0,01 ; p<0,001$ respectively). The E III group ingested less ration than $\mathrm{CI}(p<0,05)$ and $E$ II $(p<0,05)$ groups.

Key words: Laboratory animals. Thermoelectric modules. Temperature. Microenvironment. 


\section{LISTA DE FIGURAS}

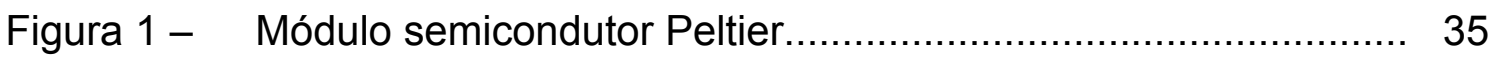

Figura 2 - Diagrama ilustrativo de um módulo termoelétrico simples. "P" e "N" são as pastilhas de $\mathrm{Bi}_{2} \mathrm{Te}_{3}$ posicionadas de forma a permitir a passagem da energia elétrica; "C" são lâminas de cobre.

Figura 3 - Montagem completa do MT, notar pastilhas de $\mathrm{Bi}_{2} \mathrm{Te}_{3}$ e as lâminas de cobre.

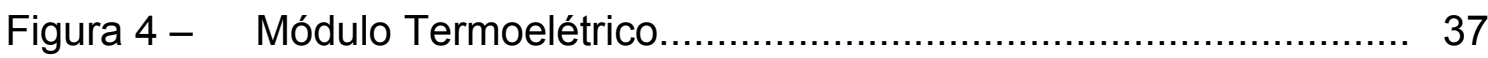

Figura 5 - Tubo de PVC Aquapluv Style ${ }^{\circledR}$ selecionado para constituir a CC de ar. Notar as janelas de acomodação dos módulos Peltier

Figura 6 - Secção transversal da câmara de condicionamento contendo o trocador de calor interno.

Figura 7 - Trocador de calor com seu respectivo microventilador.

Figura 8 - Finalização da montagem da gincana de condicionamento de ar, em PVC.

Figura 9 - Conclusão da montagem da gincana de condicionamento com todos os semicondutores e seus trocadores de calor.

Figura 10 - Detalhamento do isolante térmico ao redor do duto de condicionamento e da base do dissipador externo.

Figura 11 - Término da montagem do sistema de condicionamento de ar.. 43

Figura 12 - Componentes da fonte de alimentação

Figura 13 - Dissipador externo a água

Figura 14 - Lâminas de vidro para fechamento do dissipador a água. 46

Figura 15 - Trocador de calor externo a água.

Figura 16 - Adaptação do trocador de calor interno. 
Figura 17 - Módulo Peltier e seu trocador de calor interno na gincana de PVC

Figura 18 - Montagem final do dissipador a água..................................... 49

Figura 19 - Visão panorâmica da gincana de condicionamento................... 50

Figura 20 - Condicionador microambiental retilíneo.................................. 51

Figura 21 - Módulo de condicionamento térmico. Notar em (A) Entrada de água de arrefecimento; (B) Saída de água de arrefecimento e (C) Alimentação do módulo termoelétrico

Figura 22 - Ventilador centrífugo. (A) Controlador de tensão...................... 53

Figura 23 - Caixa de isolamento térmico (CIT) ...................................... 54

Figura 24 - Cobertura de acrílico removível.............................................. 55

Figura 25 - Trecho rígido do duto de exaustão da CIT ............................... 56

Figura 26 - Segundo trecho, flexível, da linha de exaustão......................... 57

Figura 27 - Terceiro trecho, rígido, da linha de exaustão. Notar no ângulo superior direito da foto a descarga do recinto para o exterior.... 57

Figura 28 - Vista inferior da flange de insuflação........................................ 58

Figura 29 - Vista lateral da flange de insuflação........................................ 58

Figura 30 - Controlador eletrônico digital microprocessado.......................... 59

Figura 31 - Sensor de temperatura no duto de insuflação............................ 59

Figura 32 - Controlador Eletrônico modelo TLZ12 …………………….... 60

Figura 33 - Figura do sensor do CE.................................................... 61

Figura 34 - Painel de controle elétrico....................................................... 62

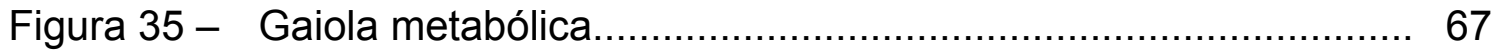

Figura 36 - Gaiolas metabólicas no interior da CIT .................................. 68

Figura 37 - Variação de entalpia utilizando condicionador tipo gincana com dissipação externa a ar. (A) Temperatura de bulbo seco inicial; (B) Temperatura de bulbo úmido inicial; (C) Temperatura de bulbo seco final; (D) Temperatura de bulbo úmido final; (E) Entalpia inicial e $(F)$ Entalpia final. 
Figura 38 - Variação de entalpia utilizando condicionador tipo gincana com dissipação externa a água. (A) Temperatura de bulbo seco inicial; (B) Temperatura de bulbo úmido inicial; (C) Temperatura de bulbo seco final; (D) Temperatura de bulbo úmido final; (E) Entalpia inicial e (F) Entalpia final.................... 78

Figura 39 - Curva de ingestão de ração, em gramas, por grupo $(n=15) \ldots \ldots .93$

Figura 40 - Curva de ganho de peso, em gramas, por grupo $(n=15) \ldots \ldots \ldots . .95$ 


\section{LISTA DE TABELAS}

Tabela 1 - Temperaturas $\left({ }^{\circ} \mathrm{C}\right)$ dos 12 termômetros no sistema de condicionamento tipo gincana com dissipação externa a ar, durante as 21 séries de medições. Condições elétricas de operação: tensão de alimentação de 15 volts por semicondutor, consumo total de 7,35 amperes e potência de 1212,75 watts por hora. Velocidade do ar condicionado de $1 \mathrm{~m} / \mathrm{s}$ e vazão de 5,82 litros por segundo - São Paulo 2005.

Tabela 2 - Temperaturas $\left({ }^{\circ} \mathrm{C}\right)$ dos 12 termômetros no sistema de condicionamento tipo gincana com dissipação externa a ar após 20 minutos do início do ensaio. Condições elétricas de operação: tensão de alimentação de 15 volts por semicondutor, consumo total de 7,35 amperes e potência de 1212,75 watts por hora. Velocidade do ar condicionado de $1 \mathrm{~m} / \mathrm{s}$ e vazão de 5,82 litros por segundo - São Paulo 2005

Tabela 3 - Temperaturas $\left({ }^{\circ} \mathrm{C}\right)$ dos 12 termômetros no sistema de condicionamento tipo gincana com dissipação externa a água, durante as 21 séries de medições. Condições elétricas de operação: tensão de alimentação de 9 volts por semicondutor, consumo total de 5,3 amperes e potência de 524,7 watts por hora. Velocidade do ar condicionado de $1 \mathrm{~m} / \mathrm{s}$ e vazão de 5,82 litros por segundo. Vazão de água de arrefecimento de 1 litro por minuto - São Paulo - 2005 .

Tabela 4 - Temperaturas $\left({ }^{\circ} \mathrm{C}\right)$ dos 12 termômetros no sistema de condicionamento tipo gincana com dissipação externa a água após 20 minutos do início do ensaio. Condições elétricas de operação: tensão de alimentação de 9 volts por semicondutor, consumo total de 5,3 amperes e potência de 524,7 watts por hora. Velocidade do ar condicionado de $1 \mathrm{~m} / \mathrm{s}$ e vazão de 5,82 litros por segundo. Vazão de água de arrefecimento de 1 litro por minuto - São Paulo - 2005

Tabela 5 - Ingestão de ração (em gramas) e ganho de peso dos animais (em gramas). Grupo Controle (C I) - animais C1 a C15, mantidos a $22 \pm 2^{\circ} \mathrm{C}$ em sistema de condicionamento de ar convencional - São Paulo - 2006

Tabela 6 - Ingestão de ração (em gramas) e ganho de peso dos animais (em gramas). Grupo Controle (C II) - animais C1 a C15, mantidos a $22 \pm 0,1^{\circ} \mathrm{C}$ em sistema de condicionamento microambiental sem direcionamento de ar - São Paulo 2006 
Tabela 7 - Ingestão de ração (em gramas) e ganho de peso dos animais (em gramas). Grupo Experimental (E I) - animais E1 a E15, mantidos a $22 \pm 0,1^{\circ} \mathrm{C}$ em sistema de condicionamento

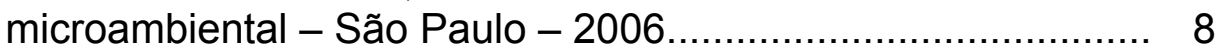

Tabela 8 - Ingestão de ração (em gramas) e ganho de peso dos animais (em gramas). Grupo Experimental (E II) - animais E1 a E15, mantidos a $24 \pm 0,1^{\circ} \mathrm{C}$ em sistema de condicionamento microambiental - São Paulo - 2006.

Tabela 9 - Ingestão de ração (em gramas) e ganho de peso dos animais (em gramas). Grupo Experimental (E III) - animais E1 a E15, mantidos a $26 \pm 0,1^{\circ} \mathrm{C}$ em sistema de condicionamento microambiental - São Paulo - 2006.

Tabela 10 - Ingestão de ração (em gramas) e ganho de peso dos animais (em gramas). Grupo Experimental (E IV) - animais E1 a E15, mantidos a $28 \pm 0,1^{\circ} \mathrm{C}$ em sistema de condicionamento microambiental - São Paulo - 2006.

Tabela 11 - Ingestão de ração (em gramas) e ganho de peso dos animais (em gramas). Grupo Experimental (E V) - animais E1 a E15, mantidos a $30 \pm 0,1^{\circ} \mathrm{C}$ em sistema de condicionamento microambiental - São Paulo - 2006.

Tabela 12 - Ingestão de ração total (em gramas) por animal / grupo $(n=15)$, durante 5 dias - São Paulo - 2006.

Tabela 13 - Ganho de peso total (em gramas), por animal / grupo $(n=15)$, durante 5 dias - São Paulo - 2006

Tabela 14 - Concentração de gás de amônia (em ppm), por dia / grupo, no decorrer de 5 dias, $n=5$ - São Paulo - 2006 


\section{LISTA DE ABREVIATURAS}

${ }^{\circ} \mathrm{C}^{*} \quad$ graus Celsius

$A^{*} \quad$ ampère

Bi2Te3 Telureto de Bismuto

BTU Unidade Térmica Britânica (British Thermal Unit)

CC Câmara de Condicionamento

CE Controlador Eletrônico

CEDM Controlador eletrônico digital microprocessado

CIT Caixa de isolamento térmico

$\mathrm{CM} \quad$ Condicionador microambiental

$\mathrm{CO}_{2} \quad$ Gás Carbônico

FCS Fator de calor sensível

FEM Força eletromotriz

kcal $^{*} \quad$ kilocaloria

$\mathrm{kJ}^{*} \quad$ kilojoule

$\mathrm{kW}^{*} \quad$ kilowatts

LAMBDA Laboratório de Ambiência de Biotérios e Desenvolvimentos Alternativos

LBA Lavado bronco-alveolar

MFPIV Micro Fan Pressurized and Intra Ventilated (pressurizado e intraventilado por microventiladores)

$\mathrm{m} / \mathrm{s}^{*} \quad$ Unidade de velocidade (metros / segundo)

$\mathrm{m}^{3} / \mathrm{kg}^{*} \quad$ metro cúbico por kilograma

MT's Módulos termoelétricos

$\mathrm{mV}^{*} \quad$ Milivolt

n Número de amostras

$\mathrm{O}_{2} \quad$ Oxigênio

$P_{D} \quad$ Potência dissipada

ppm Partes por milhão

$\mathrm{P}_{\mathrm{T}} \quad$ Potência total

$\mathrm{Pu}_{\mathrm{U}} \quad$ Potencia útil

\footnotetext{
" Unidade em concordância com o Sistema Internacional de Unidades - SI e ratificado pela Resolução n¹2 de 1988 do Conselho Nacional de Metrologia, Normalização e Qualidade Industrial - Conmetro (Anexo A)
} 
PVC Policloreto de vinila

$s^{*} \quad$ Segundo(s)

SOTT Sistema operando com tecnologia termoelétrica

SPF Specific Pathogen Free (livre de patógenos específicos)

TBU Temperatura de Bulbo Úmido

TBS Temperatura de Bulbo Seco

TempC Temperatura do ar condicionado

TempE Temperatura do ar externo

TempF Temperatura final

Tipo N Semicondutor Tipo Negativo

Tipo P Semicondutor Tipo Positivo

TT Tecnologia termoelétrica

TTH Tratamento termohigrométrico

$\mathrm{V}^{*} \quad$ Volts

VGD Ventilação Geral Diluidora

VMA Ventilação microambiental

VolC Volume de ar condicionado

VolE Volume de ar externo, não condicionado

$\mathrm{W}^{*} \quad$ Watts (unidade de potência elétrica)

$\mathrm{W} / \mathrm{h}^{*} \quad$ Watts por Hora (consumo elétrico)

\footnotetext{
* Unidade em concordância com o Sistema Internacional de Unidades - SI e ratificado pela Resolução n¹2 de 1988 do Conselho Nacional de Metrologia, Normalização e Qualidade Industrial Conmetro (Anexo A)
} 


\section{LISTA DE SÍMBOLOS}

$\begin{array}{ll}\Delta \mathrm{t} & \text { Diferença de temperatura } \\ \cong & \text { Aproximadamente } \\ \Delta \mathrm{t}_{\text {máx }} & \text { Diferença máxima de Temperatura } \\ \mu \mathrm{F} & \text { Microfarads } \\ t & \text { Temperatura de bulbo seco, TBS }\left({ }^{\circ} \mathrm{C}\right) \\ t_{u} & \text { Temperatura de bulbo úmido, TBU }\left({ }^{\circ} \mathrm{C}\right) \\ p_{v} & \text { Pressão parcial de vapor d'água }(\mathrm{mmHg}) \\ w & \text { Umidade absoluta }(\mathrm{kg} / \mathrm{kg} \text { de ar seco }) \\ \psi & \text { Umidade relativa }(\%) \\ v & \text { Volume específico }\left(\mathrm{m}^{3} / \mathrm{kg} \text { de ar seco) }\right. \\ t_{0} & \text { Ponto de orvalho }\left({ }^{\circ} \mathrm{C}\right) \\ i & \text { Entalpia (kcal ou } \mathrm{kJ} / \mathrm{kg} \text { de ar seco) } \\ \phi & \text { Grau de saturação }(\%) \\ \eta & \text { Rendimento }\end{array}$




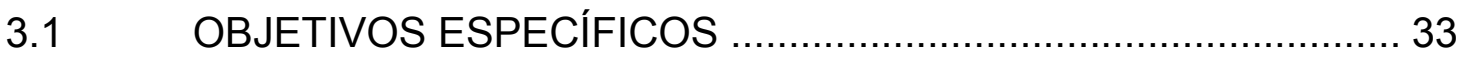

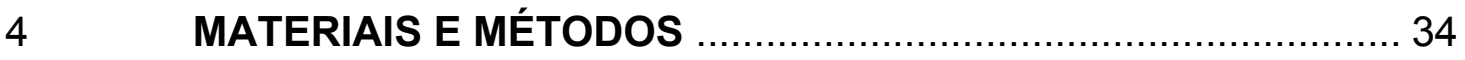

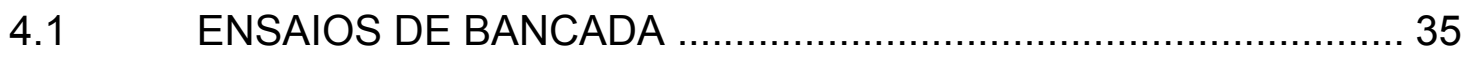

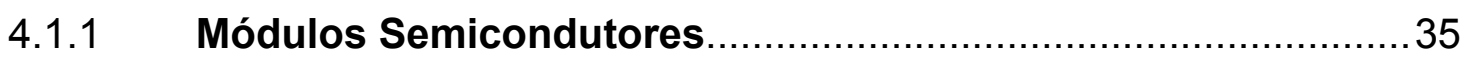

4.1.2 Condicionadores de Ar por Efeito Peltier................................ 37

4.1.2.1 Projeto da Câmara de Condicionamento (CC) .............................. 37

4.1.2.2 Condicionador Tipo Gincana com Dissipação Externa a Ar............39

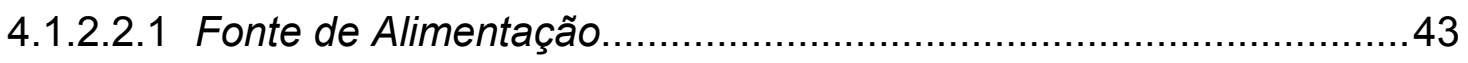

4.1.2.3 Condicionador Tipo Gincana com Dissipação Externa a Água.......44

4.1.2.4 Condicionador Tipo Retilíneo com Dissipação Externa a Água...... 50

4.1.2.4.1 Condicionador Microambiental (CM) ......................................... 51

4.1.2.4.2 Caixa de Isolamento Térmico (CIT) .............................................54

4.1.2.4.3 Painel de Controle Elétrico da CIT .............................................. 58

4.1.3 Teste de Rendimento dos Sistemas ........................................... 63

4.1.4 Comparação de Custo de Implantação por BTU Gerado............65

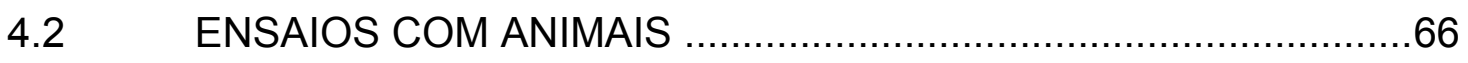

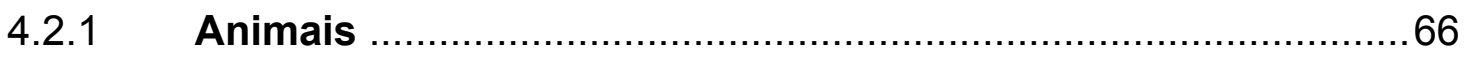

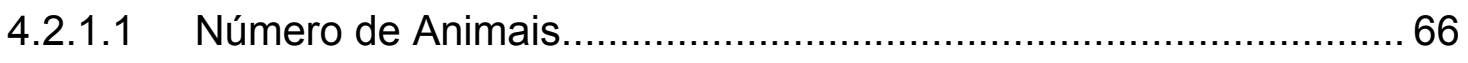

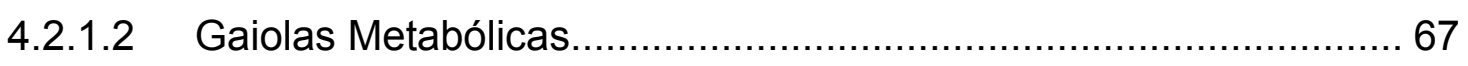

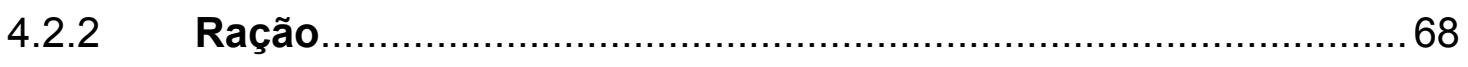

4.2.3 Água 


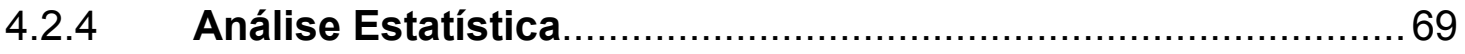

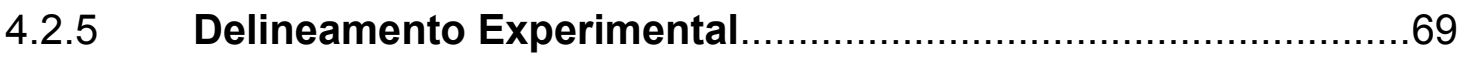

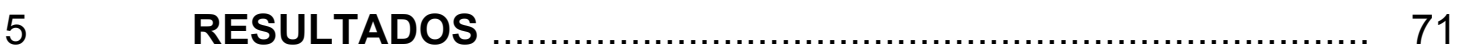

5.1 DESEMPENHO DO CONDICIONADOR TIPO GINCANA COM

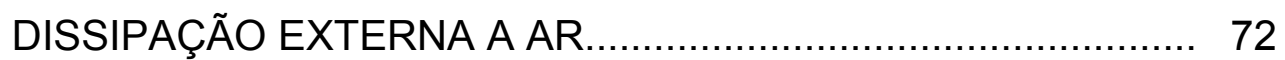

5.2 DESEMPENHO DO CONDICIONADOR TIPO GINCANA COM DISSIPAÇÃO EXTERNA A ÁGUA ................................. 76

5.3 SIMULAÇÃO MATEMÁTICA DE OPERAÇÃO DOS SISTEMAS....80

5.3.1 Comparação de Custo de Implantação por BTU Gerado...........82

5.3.2 Comparação do Consumo Elétrico por BTU Gerado................ 82

5.4 GANHO DE PESO E INGESTÃO DE RAÇÃO............................83

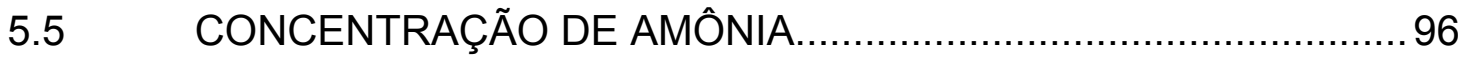

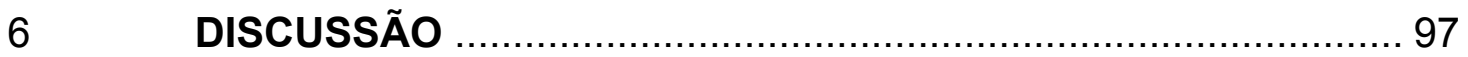

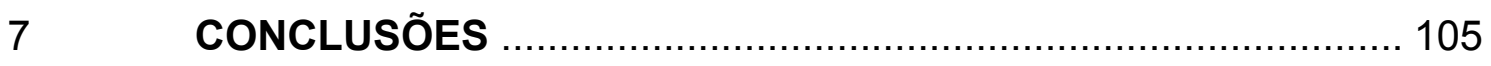

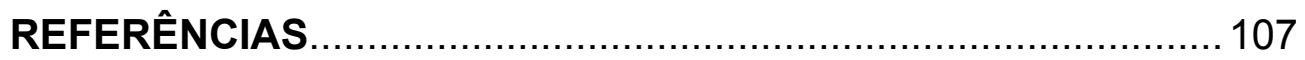

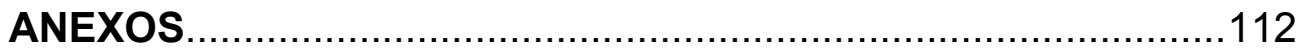


O controle atmosférico em ambientes confinados, independente do beneficiário final, pode ser dividido em três etapas genéricas: i) controle de particulados; ii) tratamento termohigrométrico e iii) distribuição. Na dependência das exigências do projeto e das necessidades do usuário, maior ou menor grau de complexidade poderá ser adotado para cada etapa ou, até mesmo, ocorrer exclusão de determinadas etapas.

Com relação a roedores de laboratório, diversos experimentos foram realizados no $L A M B D A$ (Laboratório de Ambiência de Biotérios e Desenvolvimentos Alternativos) do Departamento de Patologia da Faculdade de Medicina Veterinária e Zootecnia da Universidade de São Paulo, no que se refere à etapa "distribuição", visando o aperfeiçoamento e testes de sistemas de controle atmosférico microambiental.

O presente trabalho é uma continuidade desta linha de pesquisa, procurando introduzir e avaliar novas técnicas no tocante a etapa de tratamento termohigrométrico a partir da análise, aperfeiçoamento e emprego dos conhecimentos obtidos nas gerações anteriores de protótipos de ventilação microambiental.

O primeiro protótipo construído teve apenas a finalidade do estudo do efeito da movimentação da massa de ar sobre parâmetros reprodutivos e pulmonares de camundongos convencionais de laboratório. Teve, portanto, apenas o objetivo de servir como uma primeira abordagem sobre o mecanismo de convecção forçada aplicada a um animal. Não houve a preocupação de desenvolvimento de um eventual produto aplicativo para biotérios; sua concepção de desenho dificilmente poderia ser empregada na prática porque induziria alterações na rotina operacional e de consumo, as quais não seriam compatíveis com uma desejável relação custo/benefício. Os resultados obtidos, porém, justificaram a continuidade destes estudos, pois mostraram claramente a possibilidade de aumento de produção associada à melhoria do estado sanitário de camundongos de laboratório.

Desta continuidade, resultou um segundo projeto que não passou para a fase de protótipo, pois seu desenho induzia a algumas características que se desejava eliminar do primeiro, em particular a indução de modificações nas caixas padrão para biotérios, sendo, desta forma, considerado inviável. 
Objetivando desenvolver algo que efetivamente pudesse ser utilizado na rotina diária de criação ou manutenção de animais de laboratório, a terceira geração de protótipos foi concebida de forma a eliminar quaisquer alterações em desenho de materiais de uso corrente e padronizado em biotérios, tais como caixas e bebedouros. Os diversos experimentos realizados, nesta terceira geração, continuaram convergindo, claramente, para possibilidades cada vez maiores de implementação do já conhecido binômio produtividade/qualidade do animal. Os obstáculos relacionados à efetiva implantação na rotina foram de ordem prática, principalmente no tocante à dificuldade de balanceamento das vazões de insuflação e exaustão. Os fatores: custo de implantação e necessidade de manutenção também, poderiam ser encarados como proibitivos para a maioria das aplicações.

A quarta geração de protótipo teve tônica baseada no que foi definido como uma "evolução simplificativa", com ênfase especial para a otimização da relação custo/qualidade do animal.

Como filosofia de trabalho adotou-se, para esta quarta geração, sempre que possível, o que na prática diária do projeto e da oficina se denomina "solução de prateleira", qual seja, evitar-se ao máximo o desenvolvimento de peças, optando-se por materiais já existentes no mercado para outras aplicações técnicas, de baixo custo, de fácil aquisição e, principalmente, de certeza de produção continuada por muitos anos, em função de aplicabilidade como componente ou peça de reposição para eletroeletrônicos ou outros equipamentos em instalações de uso doméstico ou industrial.

Os aspectos de funcionalidade, robustez, aplicabilidade e pouca necessidade de manutenção também foram considerados, bem como a possibilidade de indução do menor número de alterações possíveis na rotina de um biotério. Os resultados obtidos na quarta geração, com a introdução de microventiladores de corrente contínua no processo de ventilação microambiental para roedores de laboratório, foram de extrema importância pois os animais apresentaram nível zero de lesões pulmonares, mesmo mantidos em um ambiente com a presença de particulados em suspensão. Estes pequenos ventiladores são largamente utilizados na indústria da informática. Foram obtidos dados referentes à capacidade de vazão e pressão dos microventiladores sob, basicamente, duas condições de aplicação: a) como elementos acessórios de controle de vazão para a 
terceira geração de protótipos e b) como elementos centrais de distribuição de ar para a quarta geração.

Foi nesse universo de resultados positivos, porém, ainda um tanto carente de aperfeiçoamentos técnicos, que se iniciaram os trabalhos referentes à etapa de tratamento termohigrométrico (TTH) a qual este trabalho se dedica integralmente.

O efeito do binômio temperatura e movimentação do ar sobre o conforto do ser humano é conhecido há muito tempo, final do séc. XVIII, em função do uso prático da tecnologia do condicionamento de ar. A facilidade de execução de experimentos sobre conforto em seres humanos produziu diagramas muito confiáveis. Com relação aos animais, existe vasta literatura demonstrando a influência climática em animais de produção, em especial gado leiteiro, de corte, frangos e suínos. Quanto a animais de laboratório, a pouca literatura existente relata resultados a partir de dados obtidos com ventilação e não com condicionamento de ar. Para biotérios, o padrão clássico de condicionamento de ar envolve o ciclo de compressão do gás freon, processo eficiente, porém de alto custo de instalação e de manutenção. O processo clássico de controle atmosférico para biotérios envolve vazão de $100 \%$ de ar externo o que eleva ainda mais o custo em virtude do porte do equipamento.

As novas técnicas de controle atmosférico para biotérios, a partir de sistemas microambientais, as quais se valem do mecanismo de convecção forçada (presença de uma corrente de ar constante sobre o animal), permitem o projeto de sistemas envolvendo vazões muito menores que as do processo clássico, bem como temperaturas de conforto mais elevadas que as descritas na literatura.

O presente trabalho consiste em um novo sistema de condicionamento de ar para biotérios, usando a tecnologia de controle atmosférico microambiental. Este novo sistema baseia-se no Efeito Peltier onde diferenças de temperaturas são conseguidas através da passagem de uma corrente elétrica por um módulo semicondutor que é menos eficiente que o ciclo de compressão do gás freon, porém sem as desvantagens deste, tais como: grande número de peças móveis; necessidade de mão de obra especializada; exigência de manutenção mecânica preventiva e projetos complexos. 
O moderno conceito de visão do animal de laboratório como reagente biológico advém da necessidade de modelos cada vez mais refinados, no sentido de atenderem às expectativas de experimentação, cujo nível de complexidade aprofunda-se cada vez mais.

Sob essa ótica, a Ciência de Animais de Laboratório tem contribuído em quatro grandes tópicos: i) genética; ii) microbiologia; iii) ética e legislação e iv) ambiência.

Assumindo uma visão conceitual, porém pragmática, Baumans et al. (2001) expôs seu conceito sobre o animal de laboratório em relação ao ambiente, considerando que os animais podiam ser afetados por 16 fatores físicos, químicos e microbiológicos presentes no ambiente, sendo 9 deles ligados diretamente ao controle atmosférico.

Uma série de poluentes gasosos e particulados são gerados pelos animais de laboratório, tornando-se, assim, imprescindível a sua retirada. Da mesma forma, ar novo e limpo deve ser fornecido em quantidade e qualidade adequadas (OPAS, 1968; CACC, 1980; SLAS, 1989), para o que, durante muito tempo, foi preconizado o modelo da ventilação geral diluidora (VGD), específica para conforto humano.

A amônia, um dos principais poluentes gasosos, tende a entrar em equilíbrio, em uma sala de animais, em níveis inversamente proporcionais à taxa de renovação de ar, até que sejam atingidas, aproximadamente, 20 renovações/hora (BESCH, 1985). São relacionadas a ela alterações no sistema imunológico (TARGOWSKI et al., 1984), lesões no trato respiratório (GAMBLE; CLOUGH, 1976), mudanças nos movimentos ciliares da traquéia em ratos (SERRANO, 1971), irritação ocular (OSWEILLER et al., 1985). A ACGIH (1995) considera respectivamente Threshold Limit Value e Time Weighted Average de 25 ppm para 8 horas diárias (40 horas semanais) como limite para trabalho humano.

Técnicos ou tratadores podem desenvolver processos alérgicos quando entram em contato com as partículas suspensas no ar das salas de animais onde é aplicada a VGD (FRANCIS, 1981; HUNSKAAR; FOSSE, 1990) ou resposta imune a antígenos de microorganismos específicos de roedores (DELGADO; TIMENETSKI, 2001).

Murakami (1971) e Zhang (1992) afirmam que, em salas onde se aplica a VGD, a ventilação no interior das caixas de animais pode ser deficiente, o que leva a um acúmulo de calor e de poluentes particulados e gasosos. 
A partir de meados da década de setenta, tem sido motivo de investigação - correto controle atmosférico de biotérios, que convergiu para sistemas microambientais.

Merusse (1995) propôs um sistema brasileiro, ao qual foi atribuída a nomenclatura de sistema de Ventilação Microambiental (VMA), que foi posteriormente testado com camundongos Swiss padrão convencional, mostrando baixas concentrações de amônia no interior das caixas e menor incidência de lesões pulmonares no grupo experimental (TEIXEIRA et al., 1999, 2001a), além de diminuição do intervalo entre partos, maior número de partos, maior número de filhotes nascidos, maior número de filhotes desmamados, também no grupo experimental (TEIXEIRA et al., 2001b).

No Brasil, país de elevada média de temperatura, a simples movimentação do ar, por um sistema VMA, poderia ser responsável pela retirada do calor sensível e latente das pessoas e dos animais, na dependência direta da região climática Macintyre (1990).

Carissimi et al. (2000) realizaram trabalhos experimentais com ratos, a partir de uma terceira geração do sistema VMA, cuja concepção suprimia as deficiências do primeiro. Os autores alojaram ratos machos, por 180 dias, em diferentes intervalos de trocas de cama. Os resultados levaram os autores a propor aumento no intervalo de trocas de cama para 9 dias, sem prejuízo para a saúde dos animais e com possibilidade de economia de material e mão-de-obra para o biotério.

Seguindo esta mesma linha de raciocínio, Barbosa (1999) manteve, num sistema idêntico ao de Caríssimi et al. (2000), dois grupos de ratos acasalados e mantidos em intervalos de trocas de cama de, respectivamente 7 e 14 dias. Os resultados mostraram ser viável a adoção de intervalo de 14 dias entre as trocas para ratos em acasalamento mantidos em sistemas VMA.

Chaguri et al. (2001) trabalharam com ratos em acasalamento em um sistema idêntico ao de Carissimi et al. (2000), a velocidades de ar entre 0,01 e 0,8 $\mathrm{m} / \mathrm{s}$, observando melhores índices reprodutivos e menores índices de incidência de lesões pulmonares nos grupos mantidos acima de $0,5 \mathrm{~m} / \mathrm{s}$. Além disso, os animais produzidos não apresentaram quaisquer alterações hematológicas, bioquímicas (TEIXEIRA et al., 2000) ou comportamentais (FONTES, 1999).

Martinewski (2001) introduziu uma importante alteração na concepção de sistemas microambientais para biotérios. $\mathrm{O}$ autor propôs um sistema de baixíssimo 
custo, no qual a ventilação intracaixa era efetuada por microventiladores de corrente contínua, os mesmos fabricados em larga escala como suprimento para a indústria da informática, dispostos diretamente sobre as caixas. Tal sistema dispensou a utilização da estante ventilada, e foi denominado de "Micro Fans Pressurized and Intraventiled cages" (MFPIV). O sistema foi testado com camundongos Balb/C padrão SPF em caixas tipo filtertop microventiladas. Os resultados mostraram índice zero de lesões pulmonares nos animais do grupo experimental na análise histopatológica (hematoxilina-eosina). O lavado bronco-alveolar (LBA) dos animais do grupo controle, também mantidos em caixas tipo filtertop sem microventiladores, apresentou índice de celularidade estatisticamente superior a dos animais do grupo experimental, o que significa elevado grau de inflamação do parênquima pulmonar destes animais.

O trabalho de Martinewski (2001) proporcionou o embrião da tecnologia alternativa que é proposta neste trabalho, ao seguir o caminho que é conhecido por "evolução simplificativa", demonstrando que as estruturas das estantes ventiladas, até então propostas, são perfeitamente dispensáveis, além de obter índice "zero" de lesões pulmonares.

Os resultados obtidos até o momento e o sucesso na substituição de tecnologia convencional, por alternativa menos onerosa, permitem uma outra visão sobre as novas necessidades que moldam constantemente o aperfeiçoamento tecnológico. Seguindo esta linha de raciocínio, o presente trabalho pretende analisar uma forma alternativa de TTH para o ar de insuflação de biotérios, a qual deverá operar em conjunto com o sistema VMA.

Atualmente os sistemas de TTH baseiam-se no ciclo de compressão do gás freon, o qual permite que parte da energia térmica do ar de insuflação seja removida, transferida e rejeitada para a atmosfera. Num ciclo básico de compressão de freon, o gás chega ao compressor que o remete para o condensador do sistema ou linha de alta pressão. No final do sub-ciclo de condensação, praticamente toda a massa de freon já está liquefeita, tendo perdido o calor para o ambiente. A pressão na linha de condensação é mantida elevada graças à válvula de expansão ou tubo capilar, colocado no final desta linha. Este elemento causa uma drástica redução no diâmetro da linha de freon, provocando sua liquefação no trecho anterior. A partir da válvula de expansão, o diâmetro da linha é aumentado. Este aumento provoca a evaporação do freon e, portanto, este segundo sub-ciclo recebe o nome de 
evaporador. A evaporação do freon provoca retirada de energia térmica da tubulação aletada do evaporador, pela qual, externamente, passa o ar de insuflação, que é, portanto, resfriado. A partir do evaporador, o vapor de freon aquecido retorna ao compressor, continuando o ciclo.

Os sistemas de compressão de freon são bastante eficientes na promoção de refrigeração. Em função disso, estes sistemas são responsáveis por praticamente $90 \%$ de tudo o que é resfriado no planeta. Porém, o ciclo de compressão do freon envolve considerável quantidade de peças móveis e, portanto, deve ser passível de manutenção preventiva periódica. Além disso, seu projeto e sua montagem envolvem um elevado grau de complexidade e o principal elemento do sistema, o freon, tem sido associado a danos ecológicos.

Embora a supremacia na utilização dos equipamentos baseados no ciclo de compressão do freon seja inquestionável, sabe-se que este não foi o único ciclo de refrigeração desenvolvido nem a única forma de se obter refrigeração.

Baseados em Costa (1982), uma breve retrospectiva deve ser feita a cerca de uma outra forma de obtenção do frio. Em 1821, Seebeck observou que em um circuito fechado constituído por dois metais diferentes, sempre que as duas junções forem mantidas a temperaturas diferentes, há geração de corrente elétrica. Dessa forma, verificou que diferenças de temperatura da ordem de $1.700^{\circ} \mathrm{C}$ podiam gerar diferença de potencial de $18 \mathrm{mV}$. Em 1834, Peltier observou o efeito inverso: fazendo circular uma corrente elétrica na mesma direção da FEM (força eletromotriz), gerada pelo efeito Seebeck (EFEITO, 2006, 2007c), ocorria o resfriamento dos metais no ponto de sua junção. Já, a circulação de corrente elétrica contrária à direção da FEM, aquecia o ponto da junção, caracterizando a reversibilidade do efeito. Os terminais metálicos nos quais se observava o efeito foram denominados de termopares. Estes fenômenos foram denominados de termoeletricidade e, respectivamente, Efeito Seebeck e Efeito Peltier (ROWE, 1994; EFEITO, 2007a,b). Posteriormente, Alternkirch ${ }^{1}$ (apud COSTA, 1982) demonstrou que as características termoelétricas de um material se acentuam conforme apresentem alta condutividade elétrica e baixa condutividade térmica, classificando os materiais, de acordo com o fenômeno, segundo o que denominou de Coeficiente Seebeck.

\footnotetext{
${ }^{1}$ COSTA, Ê. C. Refrigeração. São Paulo: Edgard Blucher, 1982. p. 215-221.
} 
Até o ano de 1949 não existiam materiais que permitissem aplicações industriais para a termoeletricidade (ROWE, 1994). A partir desta data, iniciou-se o desenvolvimento de novos materiais, denominados de semicondutores, que apresentavam Coeficientes Seebeck muito superiores aos dos metais e permitiram o início do desenvolvimento industrial de processos ligados à termoeletricidade.

loffe $^{2}$ (1953 apud COSTA, 1982) construiu uma câmara de 9,8 litros refrigerada a $4^{\circ} \mathrm{C}$. Posteriormente, Lindebland ${ }^{3}$ (apud COSTA, 1982) conseguiu uma câmara de 112 litros e 236 termopares, refrigerada a 4,5 ${ }^{\circ} \mathrm{C}$. Em 1955 foi sintetizado o telureto de bismuto $\left(\mathrm{Bi}_{2} \mathrm{Te}_{3}\right)$, semicondutor que permitiu diferença de temperatura da ordem de $72^{\circ} \mathrm{C}$ entre a face quente e a face fria. Durante muitos anos, a refrigeração termoelétrica permaneceu restrita a equipamentos de uso específico como, por exemplo, refrigeração aeroespacial. Atualmente, são comercializados inúmeros equipamentos de laboratório dotados de refrigeração termoelétrica, além daqueles de uso mais popular como os microrefrigeradores.

Os avanços obtidos no $L A M B D A$ no campo do controle atmosférico de biotérios permitiram que fossem claramente definidos o microambiente (interior das caixas de animais) e o macroambiente (a sala onde são mantidas as caixas de animais). Isto possibilita dois tipos específicos de controle atmosférico: i) o controle atmosférico microambiental no qual, se efetuam renovações completas de ar por hora e ii) o controle atmosférico macroambiental, voltado principalmente para o conforto humano. Dessa forma, o volume de ar a ser beneficiado com condicionamento e renovações completas (microambiente) fica drasticamente reduzido. Esta redução permite que equipamentos de menor porte, quando comparados com o sistema convencional, sejam empregados. Obviamente, o ar do macroambiente também deverá ser tratado, já que o beneficiamento para conforto humano não prevê renovações completas de ar por hora, apenas um pequeno aporte de ar externo para controlar os níveis de $\mathrm{O}_{2}$ e $\mathrm{CO}_{2}$ do ambiente.

Os procedimentos acima mencionados certamente convergem para a redução dos custos de um biotério, permitindo inclusive a adoção de equipamentos condicionadores de ar do tipo doméstico de janela para o macroambiente. Quanto ao microambiente, pode ser adotado a refrigeração termoelétrica em função das pequenas vazões de ar e cargas térmicas envolvidas. $O$ condicionador de ar para 0

${ }^{2,3}$ COSTA, Ê. C. Refrigeração. São Paulo: Edgard Blucher, 1982. p. 215-221. 
microambiente deverá, desta forma, apenas remover a carga térmica gerada pelos animais. O macroambiente e o microambiente não precisam, obrigatoriamente, ser mantidos na mesma temperatura, porém, dentro de uma faixa de temperatura e umidade do macroambiente na qual seja possível evitar a condensação nas superfícies externas do microambiente (ponto de orvalho). Esta faixa de temperatura e umidade varia conforme a região geográfica da instalação e deverá ser prevista em projeto.

A carga térmica gerada pelos animais é a quantidade de calor metabólico dissipado e, no presente estudo pode ser considerada como entalpia do sistema (microambiente), já que as demais fontes térmicas às quais o sistema está sujeito deverão ser removidas pelo equipamento da sala que abriga o microambiente (ENTALPIA, 2007).

Uma outra vantagem do equipamento termoelétrico é a facilidade de sua montagem. Além disso, tais equipamentos não necessitam de manutenções tão freqüentes pelo fato de praticamente não possuírem peças móveis, apenas pequenos ventiladores de longa vida útil e facilmente substituíveis. 
Tendo em vista as novas tecnologias disponíveis no mercado, no que se refere a tratamento termohigrométrico do ar, este trabalho teve como objetivo desenvolver e testar um protótipo de condicionador de ar para biotérios operando pelo efeito Peltier, como alternativa aos sistemas similares que operam pelo ciclo de compressão do freon.

\subsection{OBJETIVOS ESPECÍFICOS}

i) Montagem de um sistema termoelétrico de condicionamento de ar no padrão exigido para biotérios, ou seja, com renovações completas de ar por hora e que opere em conjunto com o sistema de VMA;

ii) Teste da aplicabilidade prática de módulos termoelétricos para o controle termohigrométrico microambiental para biotérios de roedores;

iii) Análise da sensação de conforto térmico de ratos de laboratório sob diferentes condições de velocidade e temperatura de ar, através da verificação da quantidade de ração ingerida, em relação a animais controle mantidos em sistema VGD $\left(22 \pm 2^{\circ} \mathrm{C}\right)$;

iv) Análise de adaptabilidade animal a diferentes condições de temperatura e velocidade do ar de insuflação;

v) Simulação matemática de operação do sistema termoelétrico com mistura de ar condicionado e não condicionado;

vi) Análise comparativa de custo de implantação e consumo de energia elétrica, por BTU gerado, entre o ciclo de freon e do termoelétrico. 
Este trabalho foi realizado em duas fases distintas, porém interligadas, intituladas, respectivamente, de "ensaios de bancada" e "ensaios com animais".

\subsection{ENSAIOS DE BANCADA}

Nesta primeira fase, essencialmente de bancada, foram realizados o projeto e testes do sistema termohigrométrico a ser utilizado na segunda fase.

\subsubsection{Módulos Semicondutores}

Após criteriosa consulta sobre os dispositivos Peltier disponíveis no mercado mundial e disponibilização desse material no Brasil, optou-se por adquirir dispositivos Peltier da empresa Advanced Thermoeletric ${ }^{1}$. Dentre os modelos de módulos termoelétricos disponíveis, foi selecionado o modelo ST-127-1.4-8.5, de $8,5 \mathrm{~A} ; 17,5 \mathrm{~V}$ de tensão máxima de alimentação, 80 watts de potência nominal, $\Delta \mathrm{t}_{\text {máx }}$ de $70^{\circ} \mathrm{C}$ a $25^{\circ} \mathrm{C}$ de temperatura ambiente, medindo $40 \times 40 \times 3,95 \pm 0,22 \mathrm{~mm}$ (Figura 1).

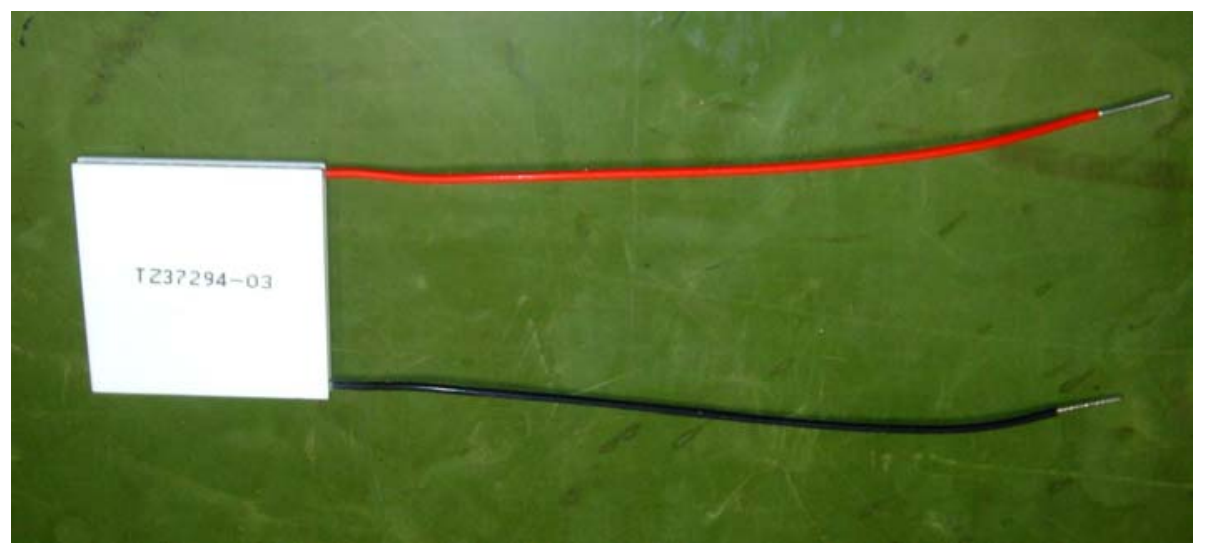

Figura 1 - Módulo semicondutor Peltier

\footnotetext{
1 Advanced Thermoeletric One Tara Blvd, Suite 101 Nashua, NH 03060 USA
} 
Atualmente, o fenômeno termoelétrico tem sido conseguido através dos módulos termoelétricos (MT's) que são o conjunto de pastilhas de $\mathrm{Bi}_{2} \mathrm{Te}_{3}$, tipo $\mathrm{P}$ e tipo N, prensadas entre lâminas de cobre e recobertas por outras duas folhas de cerâmica para o isolamento elétrico. O conjunto forma um circuito com dois pólos (positivo e negativo) por onde circula a energia elétrica (corrente contínua). Esquemas de montagem são ilustrados nas figuras 2 a 4 .

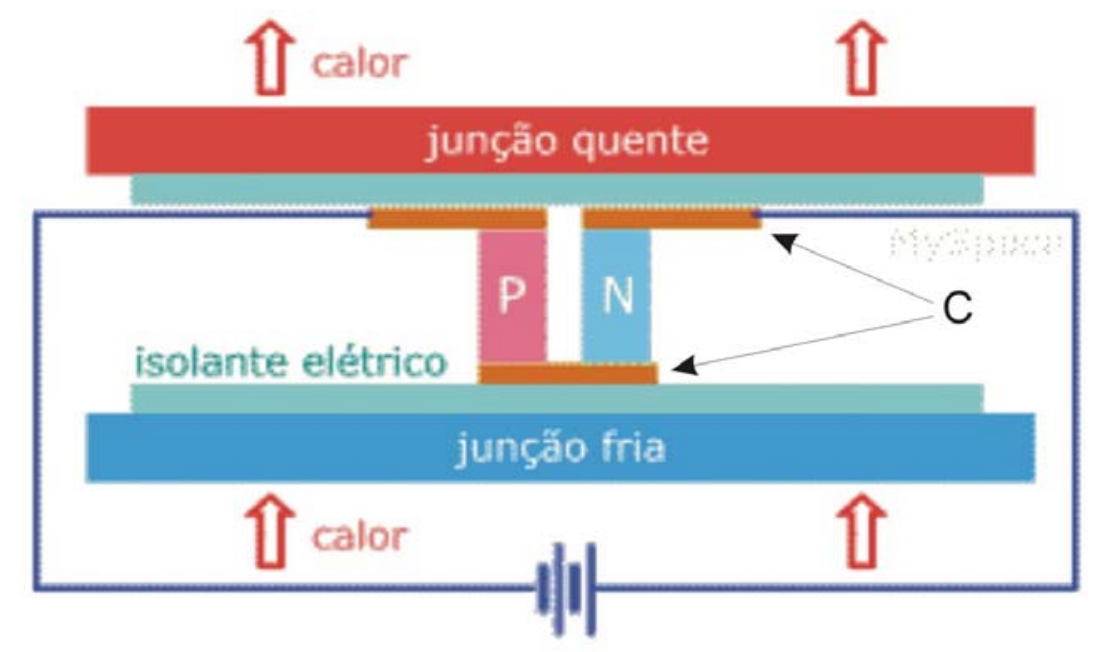

Figura 2 - Diagrama ilustrativo de um módulo termoelétrico simples. "P" e "N" são as pastilhas de $\mathrm{Bi}_{2} \mathrm{Te}_{3}$ posicionadas de forma a permitir a passagem da energia elétrica; "C" são lâminas de cobre

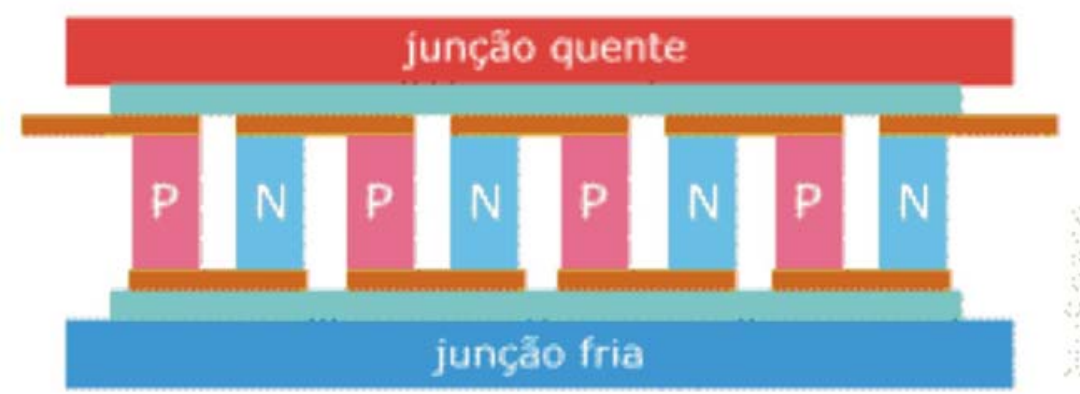

Figura 3 - Montagem completa do $\mathrm{MT}$, notar pastilhas de $\mathrm{Bi}_{2} \mathrm{Te}_{3}$ e as lâminas de cobre 


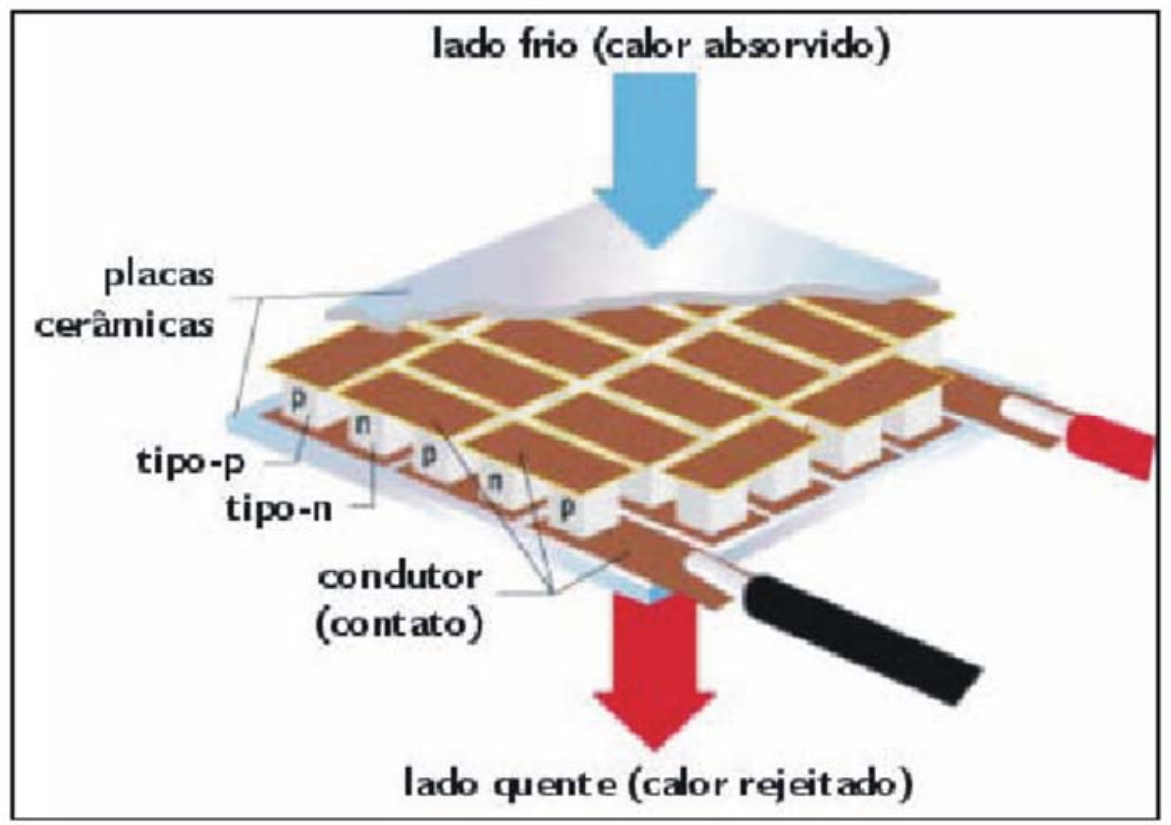

Figura 4 - Módulo Termoelétrico

Os dados técnicos do módulo termoelétrico por efeito Peltier utilizados neste trabalho estão especificados no Anexo B.

\subsubsection{Condicionadores de Ar por Efeito Peltier}

4.1.2.1 Projeto da Câmara de Condicionamento (CC)

O processo de condicionamento (refrigeração ou aquecimento) do ar destinado aos animais se dá quando este passa pelos trocadores de calor acoplados aos módulos semicondutores (Peltier). Esse fenômeno ocorre de forma gradativa à medida em que a massa de ar passa pela seqüência de aletas dos trocadores de calor localizados no interior da CC, ganhando ou perdendo energia desta forma. Os trocadores de calor foram montados de forma tal que um deles permaneça com suas aletas voltadas para o interior da CC e o outro montado com suas aletas voltadas 
para a parte externa desta mesma câmara, situando-se o módulo termoelétrico entre estes dois trocadores de calor antes mencionados.

Em vista disso, esta câmara foi redesenhada para que assumisse o formato de gincana. Foi selecionado o tubo Aquapluv Style ${ }^{2}$, medindo 100 x $65 \mathrm{~mm}$. O formato retangular foi selecionado por facilitar o acoplamento dos trocadores de calor bem como dos módulos Peltier. A partir da superfície de $100 \mathrm{~mm}$ do tubo, foram abertas janelas para a acomodação dos módulos Peltier (Figura 5).

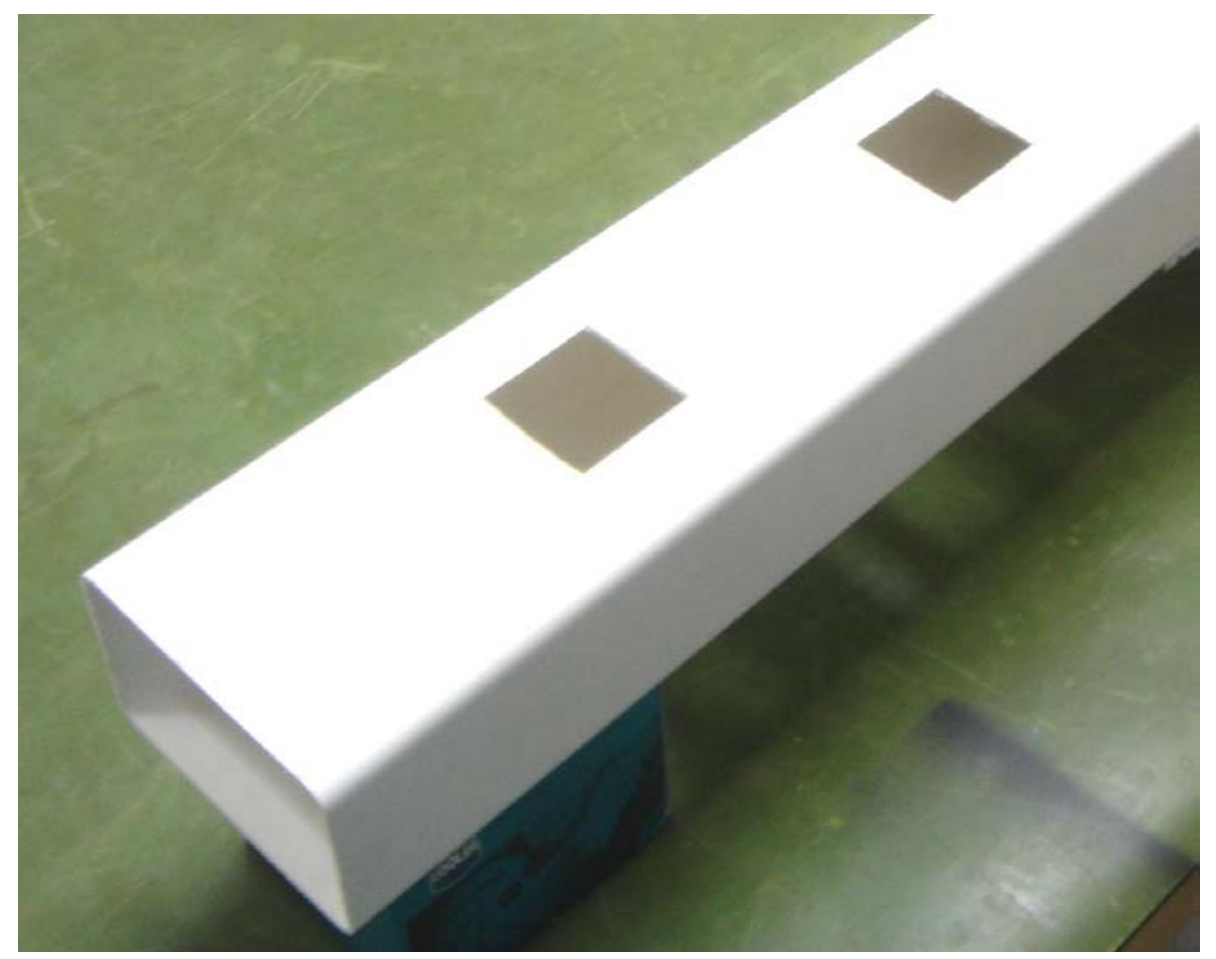

Figura 5 - Tubo de PVC Aquapluv Style ${ }^{\circledR}$ selecionado para constituir a CC de ar. Notar as janelas de acomodação dos módulos Peltier

A figura 6 mostra uma secção deste duto e o início da montagem do trocador de calor interno, responsável pelo condicionamento do ar que será insuflado para os animais.

${ }^{2}$ TIGRE S/A 


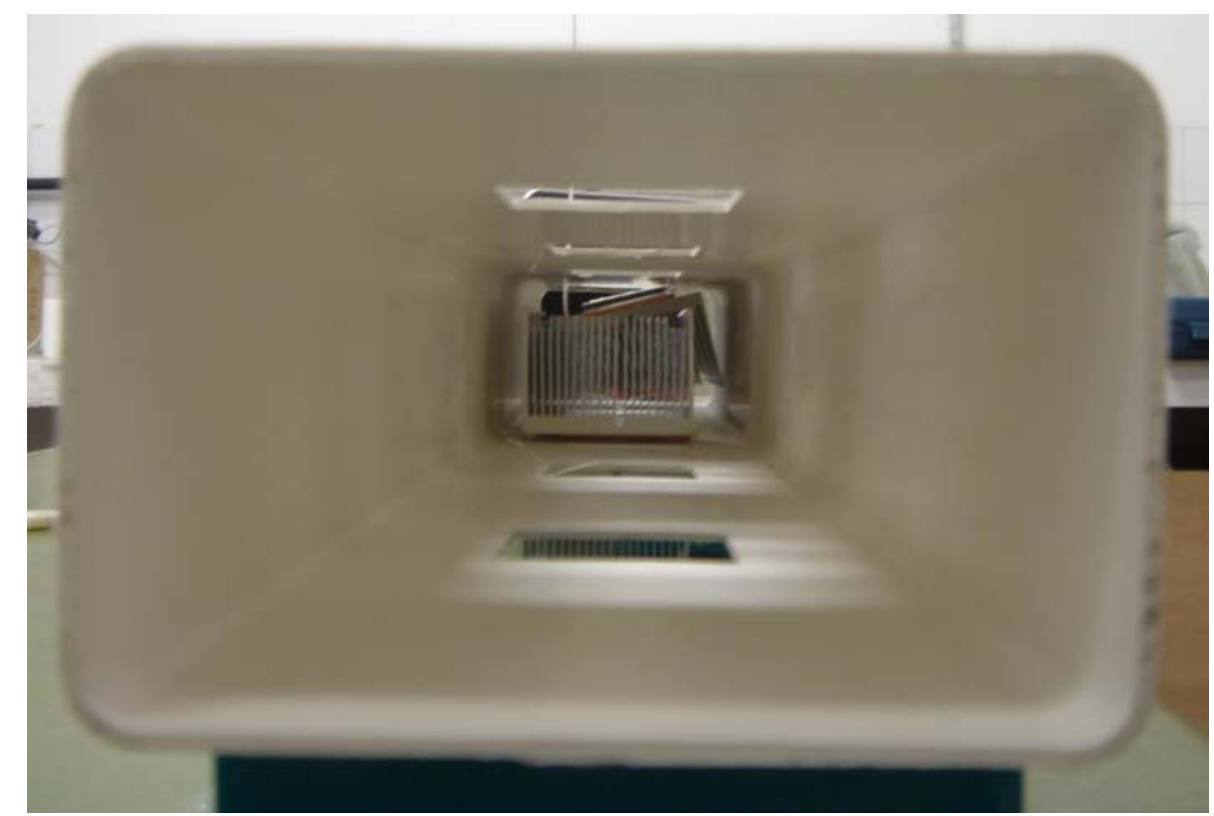

Figura 6 - Secção transversal da câmara de condicionamento contendo o trocador de calor interno

A gincana é composta por três segmentos de $70 \mathrm{~cm}$ de comprimento duas delas contendo 4 conjuntos de condicionamento (cada um composto por um módulo Peltier e dois trocadores de calor) e a terceira contendo três destes conjuntos.

\subsubsection{Condicionador Tipo Gincana com Dissipação Externa a Ar}

Tendo em vista que o efeito Peltier consiste na transferência de calor entre duas superfícies, torna-se necessária a adaptação de trocadores de energia térmica (dissipadores e absorvedores) com o intuito de aumentar a área das superfícies de troca térmica, originalmente de $16 \mathrm{~cm}^{2}$, correspondente a dimensão da face do módulo Peltier.

Os dados técnicos disponíveis esclarecem que os referidos módulos Peltier possuem uma capacidade de troca térmica de 80 watts, o que corresponde a um $\Delta \mathrm{t}_{\text {máx }}$ de $70^{\circ} \mathrm{C}$ a $25^{\circ} \mathrm{C}$ de temperatura ambiente. Estes dados mostram que esta capacidade é extremamente semelhante a geração de calor de um microprocessador de computador, em especial a um Athlon XP 3200, que apresenta uma temperatura de trabalho em torno de $80^{\circ} \mathrm{C}$. 
O trocador de calor selecionado foi o CP5-6J31C-01, fabricado pela Cooler Master $^{3}$ (Figura 7).

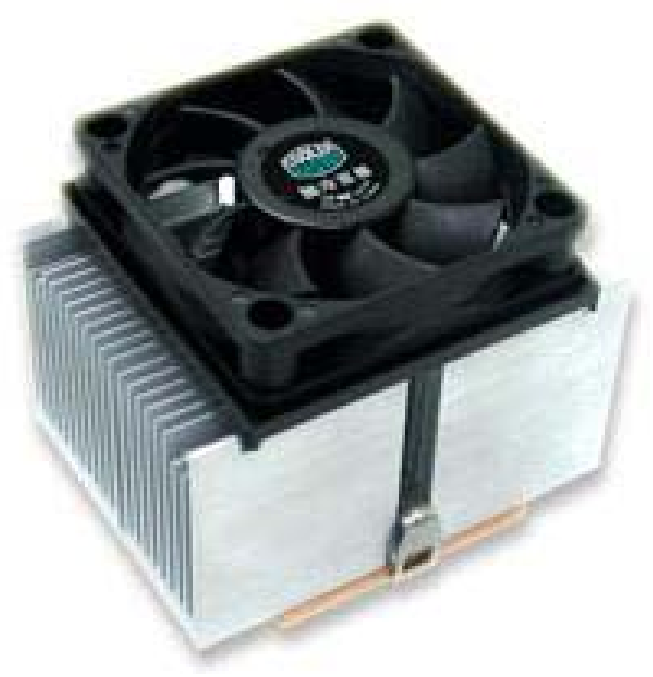

Figura 7 - Trocador de calor com seu respectivo microventilador

A seqüência de figuras a seguir (Figura 8 a 13) mostra a evolução da montagem do equipamento até o início da realização dos testes de rendimento. Ensaios de bancada apontavam para a necessidade de isolamento térmico nas paredes da gincana, o que foi feito utilizando-se isopor em placas de $10 \mathrm{~mm}$ de espessura como elemento isolante.

${ }^{3}$ Cooler Master do Brasil 


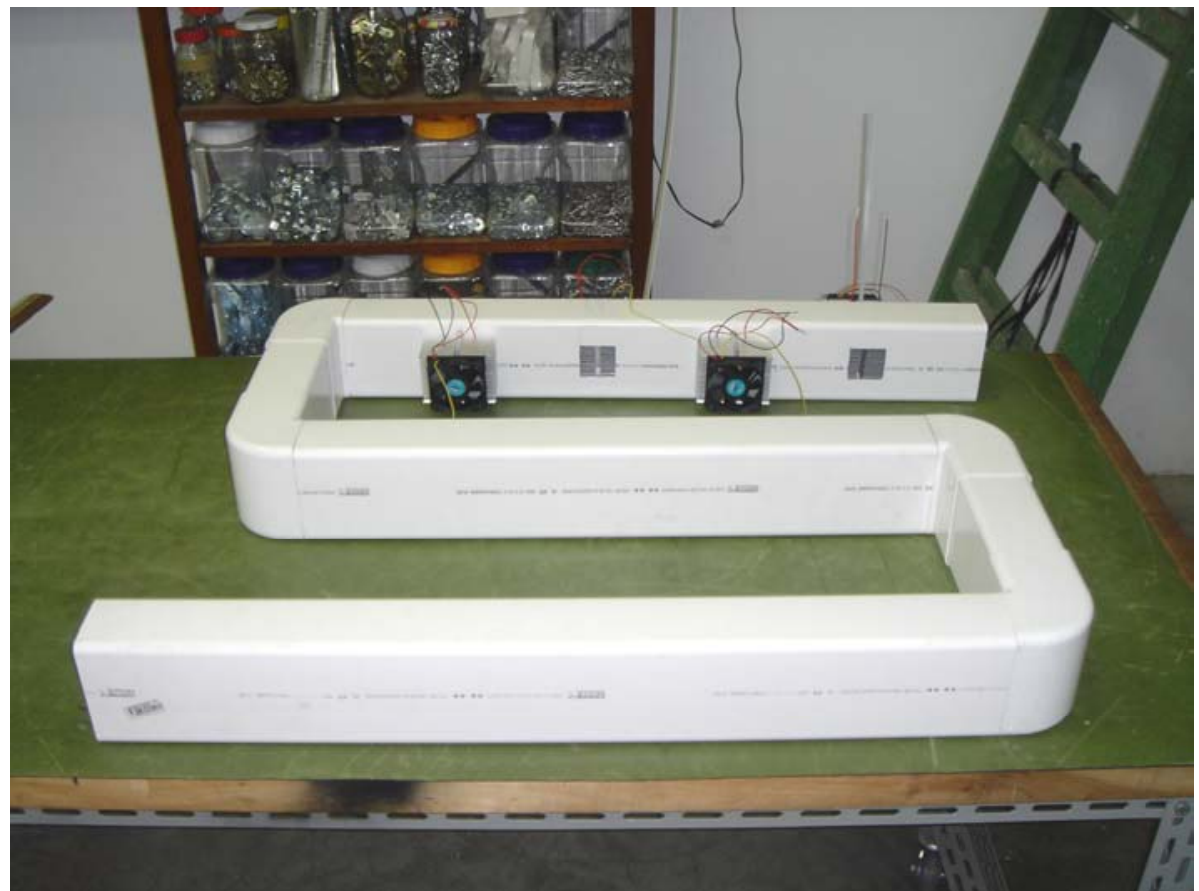

Figura 8 - Finalização da montagem da gincana de condicionamento de ar, em PVC

$\mathrm{Na}$ figura 8 pode se observar a gincana completa, já instalados os primeiros módulos semicondutores com seus respectivos dissipadores externos e internos.

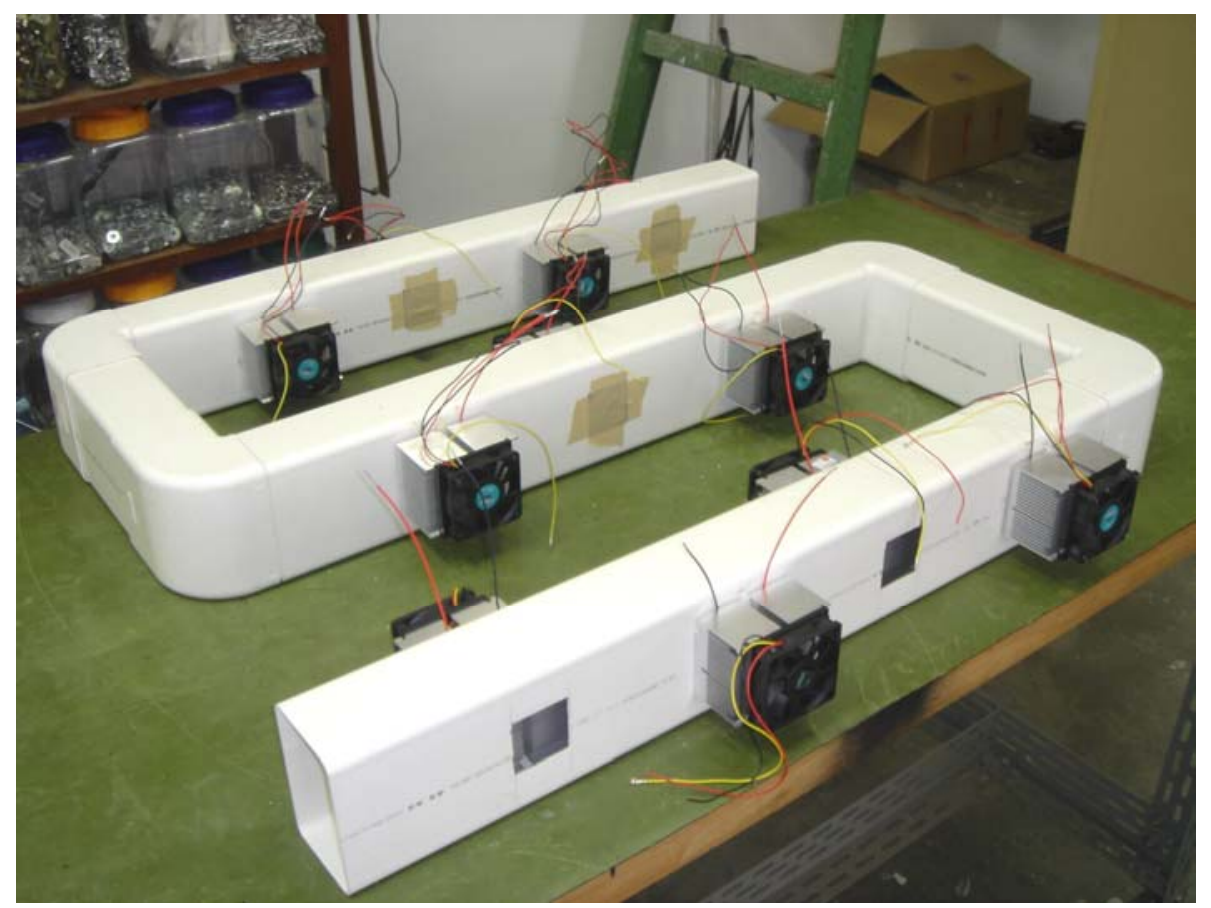

Figura 9 - Conclusão da montagem da gincana de condicionamento com todos os semicondutores e seus trocadores de calor 
A figura 9 mostra todos os conjuntos termoelétricos instalados na gincana de condicionamento. Conforme anteriormente comentado, notou-se a necessidade de isolamento térmico. A Figura 10 ilustra o detalhamento da instalação do isolante de isopor no perímetro externo do duto de condicionamento de ar.

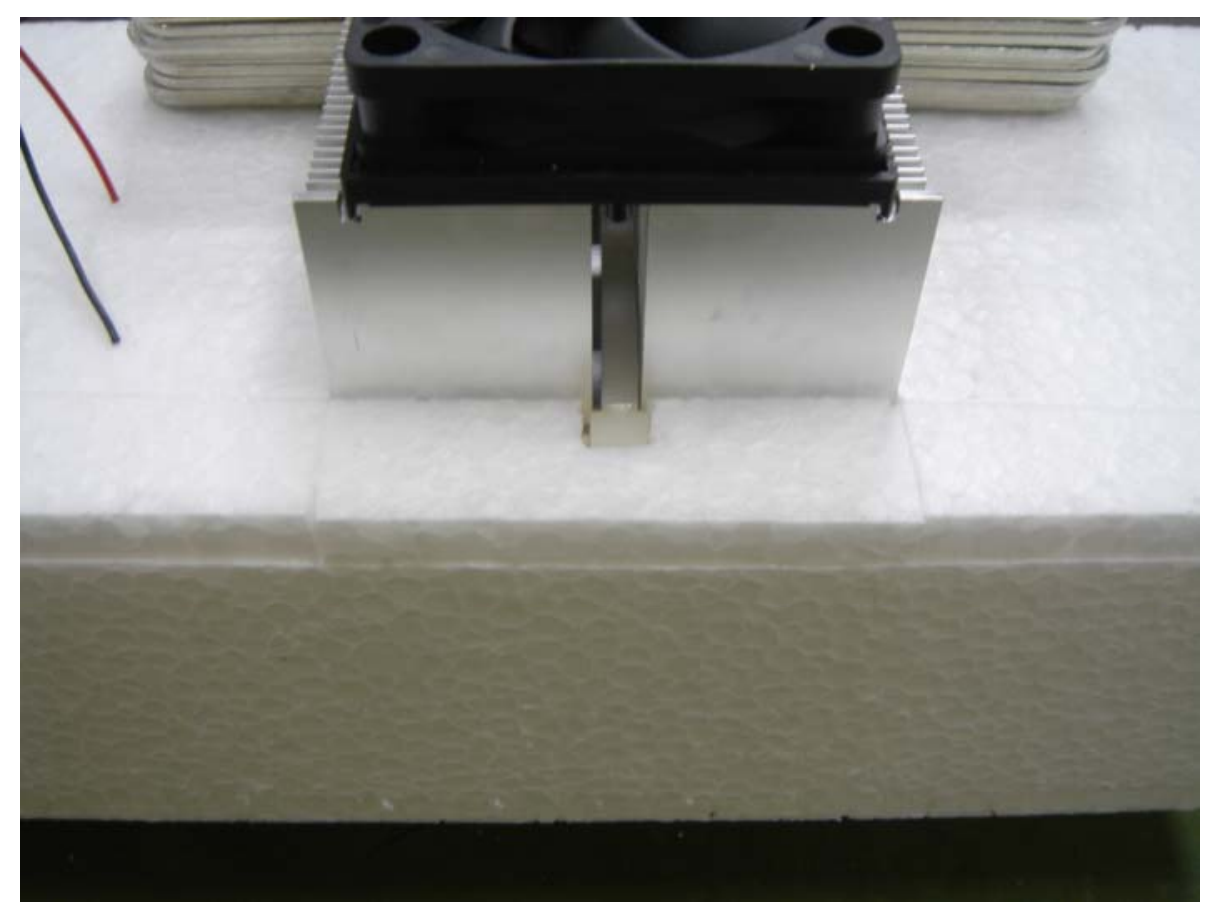

Figura 10 - Detalhamento do isolante térmico ao redor do duto de condicionamento e da base do dissipador externo

A figura 11 mostra o resultado final da montagem da gincana do sistema de condicionamento de ar. Pode-se notar seu formato final totalmente revestido por uma camada de $10 \mathrm{~mm}$ de isopor, bem como todos os conjuntos termoelétricos ligados eletricamente entre si, prontos para serem conectados à fonte de alimentação. 


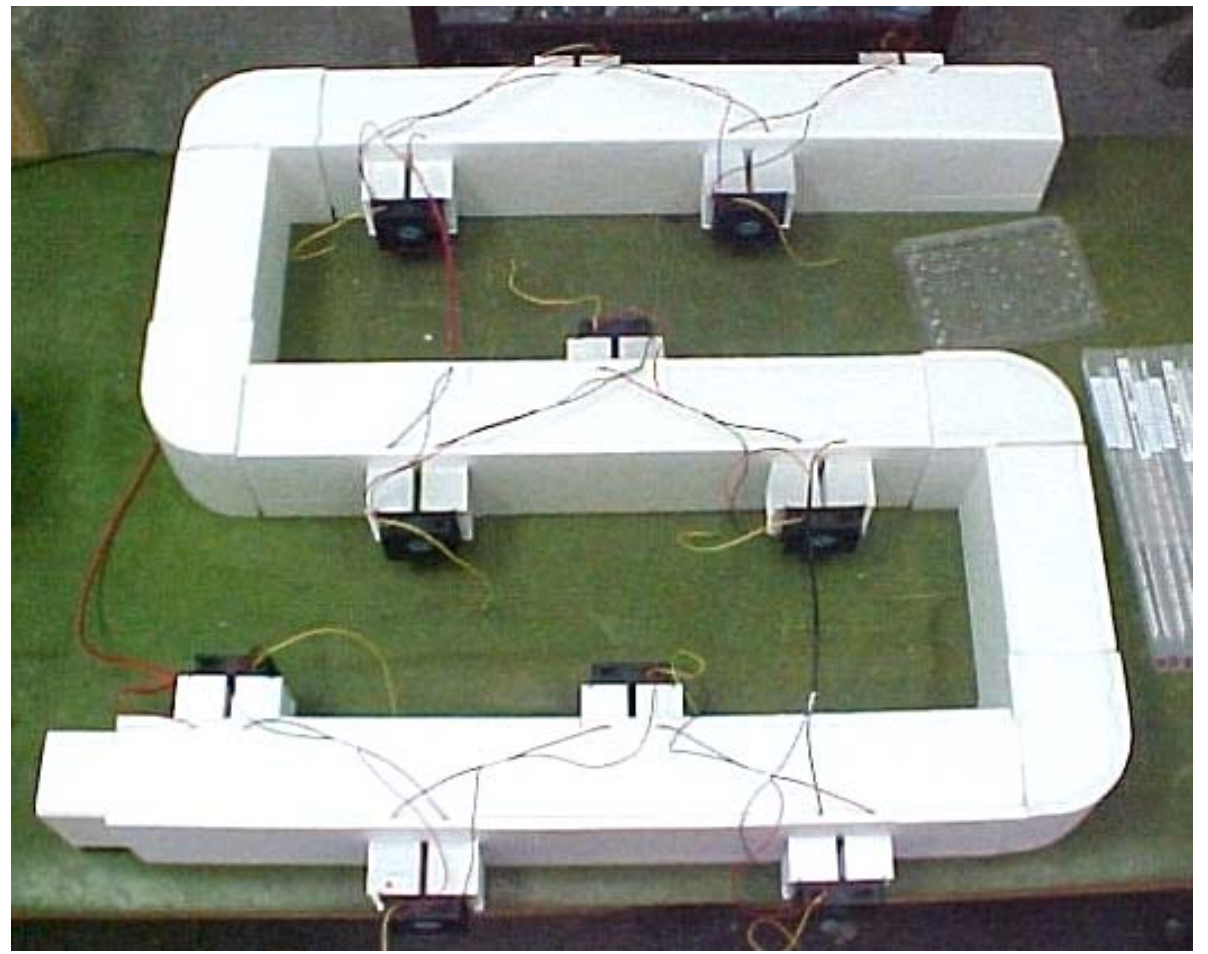

Figura 11 - Término da montagem do sistema de condicionamento de ar

\subsection{Fonte de Alimentação}

Os componentes da fonte de alimentação podem ser vistos na figura 12 . Nesta figura nota-se a tomada de energia (A) que conduz a energia da rede do prédio para o variador de tensão $(B)$ cuja função é modificar a tensão de entrada de 0 a 220 volts e transmiti-la ao transformador (C) que, por sua vez, limita o valor máximo de tensão de alimentação a 135 volts. Após o transformador, foram instalados 2 fusíveis (D) que são responsáveis pela proteção do sistema contra sobrecargas e curto-circuitos. A ponte retificadora $(E)$, composta por 4 diodos, a qual faz a retificação da energia fornecida pelo transformador, corrente alternada, transformando-a em corrente contínua que será fornecida a dois capacitores eletrolíticos $(F)$ de $6000 \mu \mathrm{F}$ por 400 volts ligados em paralelo entre si e ao circuito, cuja função é minimizar as variações de tensão provenientes da retificação da corrente elétrica. Após a saída dos capacitores, com esta concepção de circuito elétrico, obtém-se uma corrente elétrica com tensão variável a critério do 
pesquisador e das condições ambientais de acordo com cada experimento a ser executado.

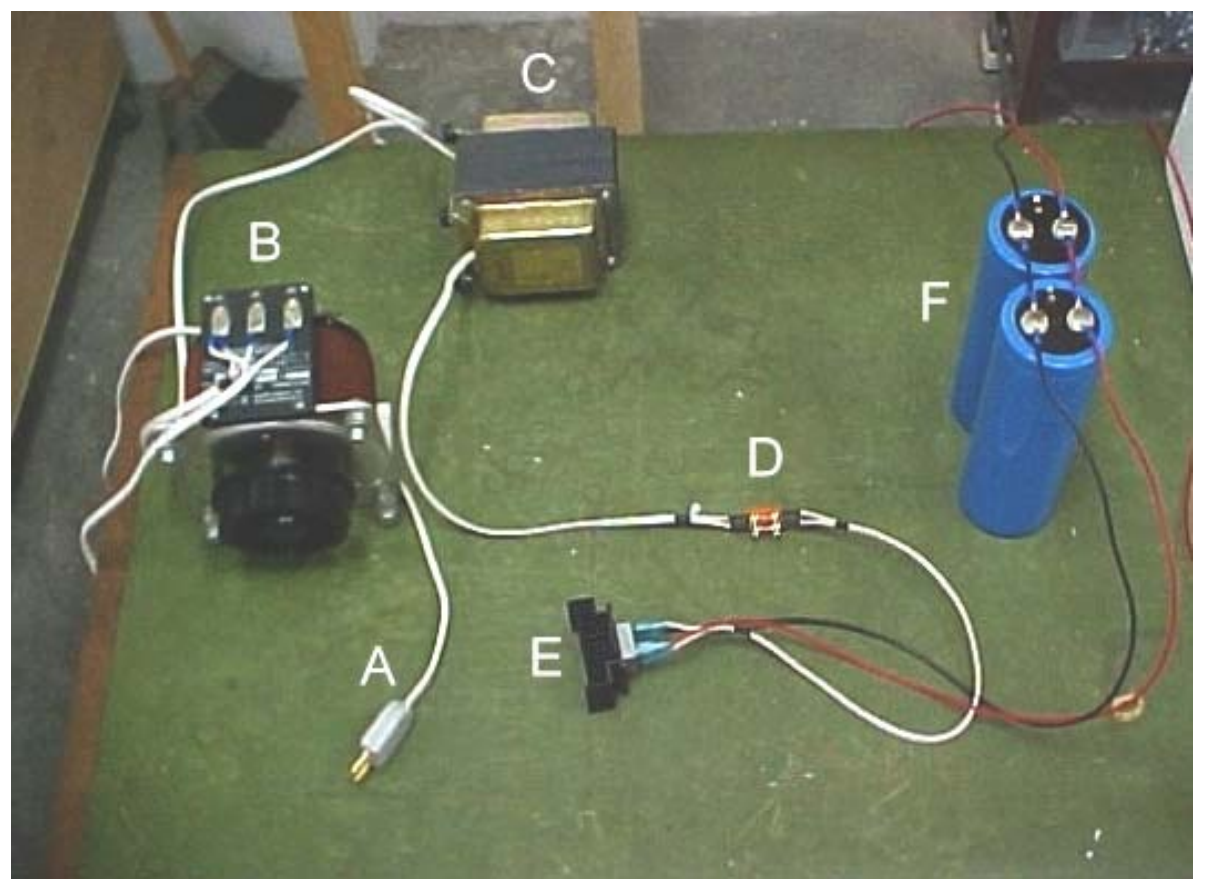

Figura 12 - Componentes da fonte de alimentação

\subsubsection{Condicionador Tipo Gincana com Dissipação Externa a Água}

Após os testes do sistema de condicionamento com troca de calor a ar procedeu-se à desmontagem dos dissipadores externos a ar, substituindo-os por dissipadores a água.

Uma rede de tubulação de água também foi implementada como mostrado nas figuras de 13 a 19.

O elemento fundamental desta nova concepção é o trocador de calor externo a água (Figura 13). Esta peça foi projetada e desenvolvida especialmente para esta função, não sendo elemento comercial. Este trocador de calor foi construído a partir de um bloco de alumínio (60 x $60 \times 13 \mathrm{~mm})$, fresado de forma a permitir sua fixação por parafusos pela aba externa de $5 \mathrm{~mm}(\mathrm{~A})$, através de 4 
orifícios (B). Internamente, o bloco foi fresado formando uma gincana com largura de $5 \mathrm{~mm}$ e profundidade de $12 \mathrm{~mm}(\mathrm{C})$.

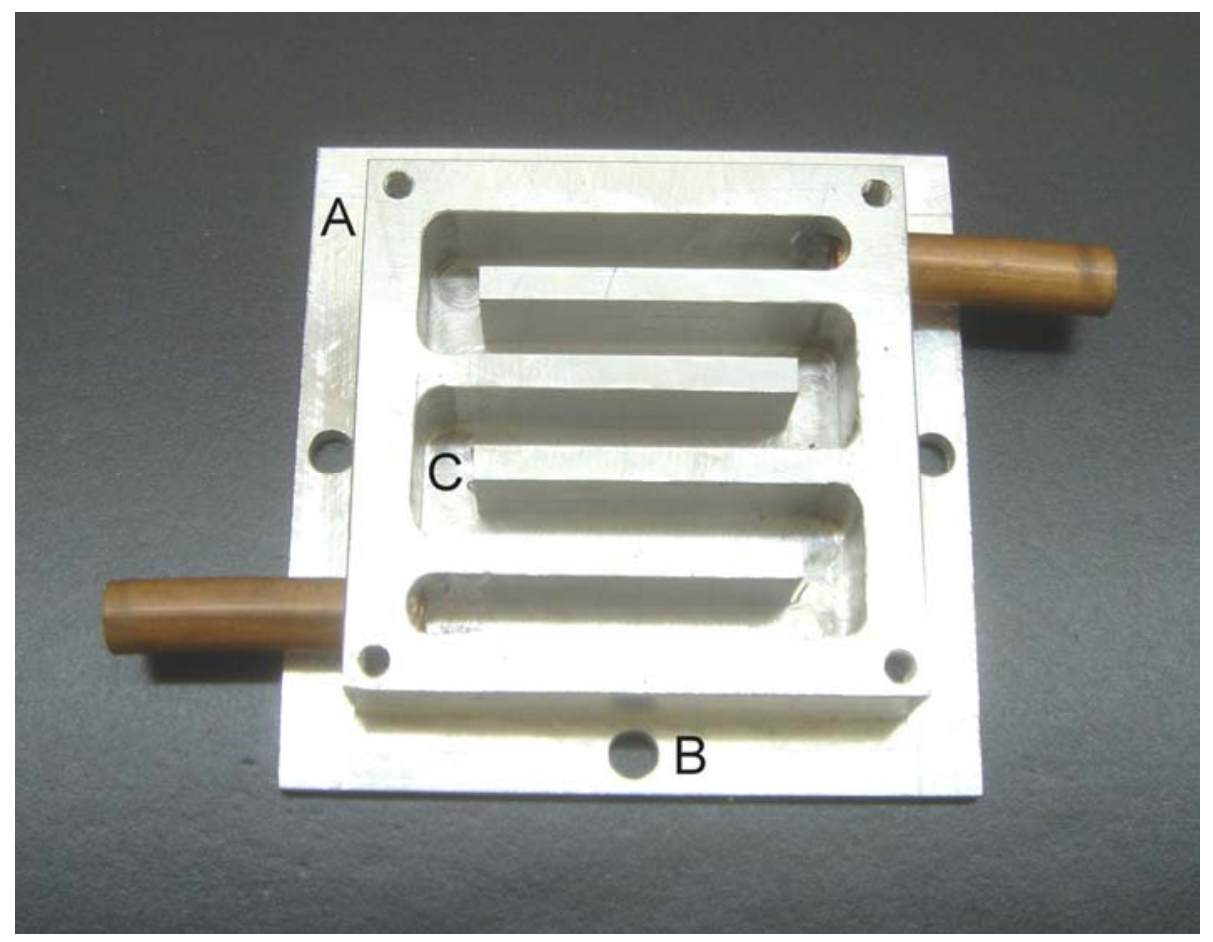

Figura 13 - Dissipador externo a água

Para facilitar a visualização desses elementos, em especial a gincana interna, o dissipador foi lacrado com uma lâmina de vidro de $3 \mathrm{~mm}$ de espessura (Figura 14), fixada ao trocador de calor por meio de cola de silicone. 


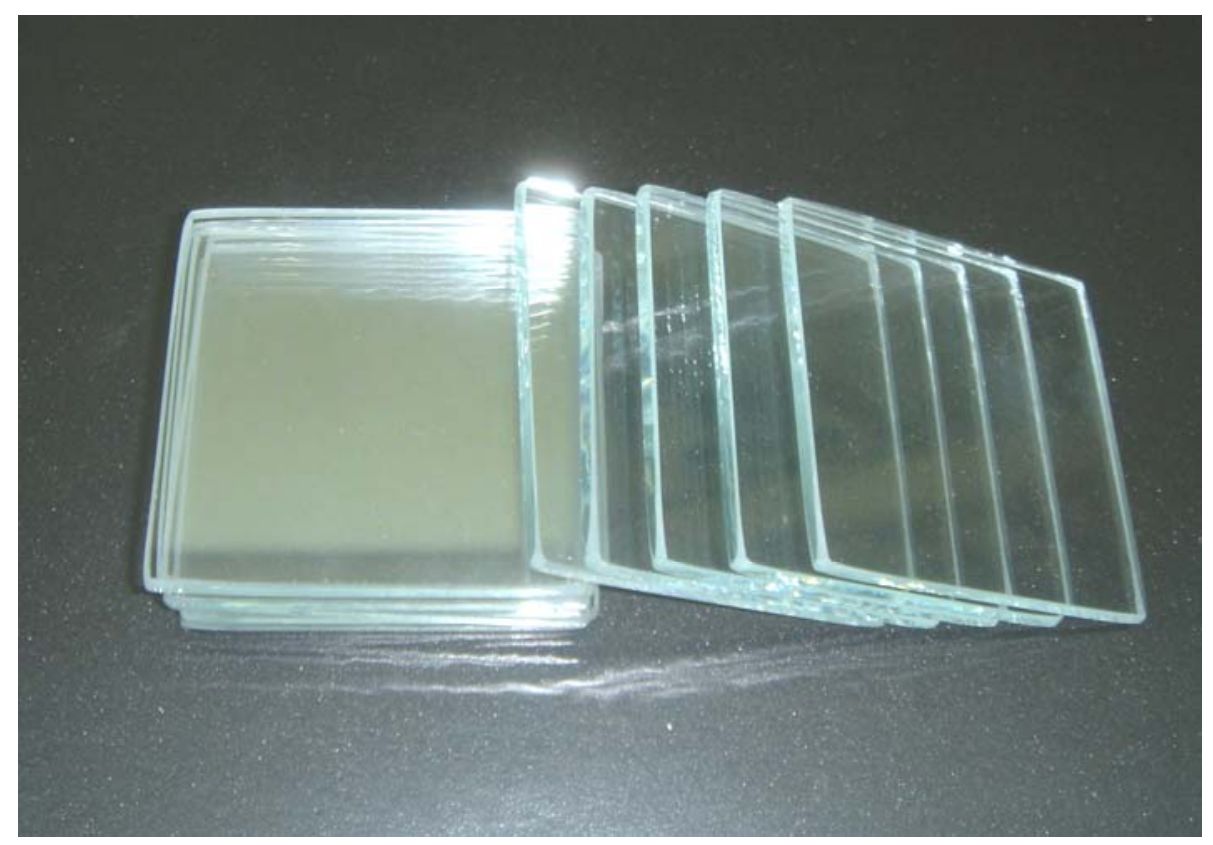

Figura 14 - Lâminas de vidro para fechamento do dissipador a água

O trocador de calor completo pode ser visto na figura 15. O fluxo de água da rede de tubulação acessa a gincana de resfriamento pela cânula de conexão de acesso $(A)$, atravessa a gincana e sai desta pela cânula de conexão de saída (B). Notar a lâmina de vidro $(C)$ colada sobre o trocador de calor.

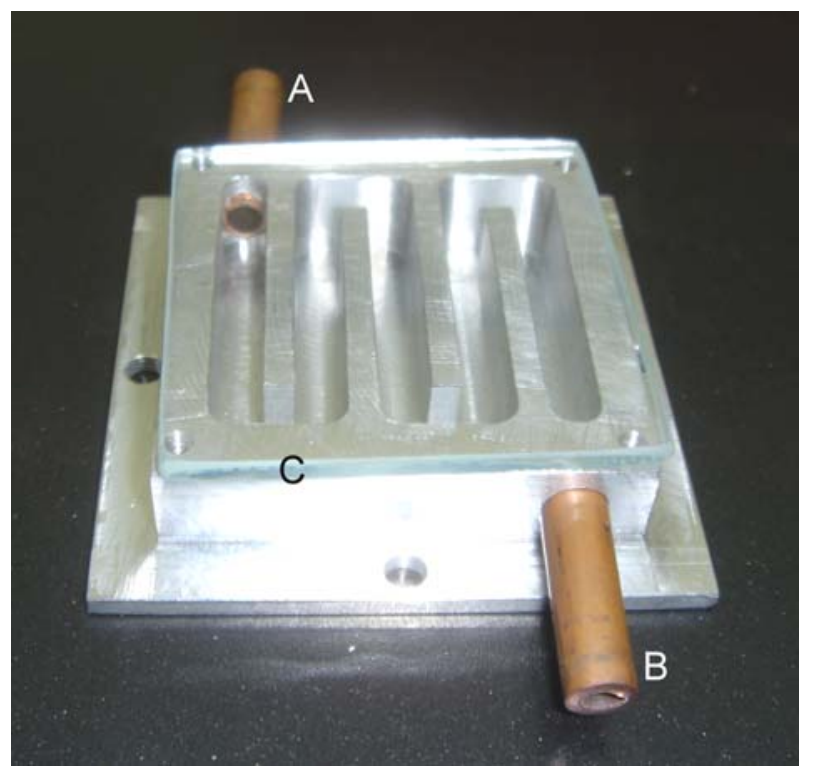

Figura 15 - Trocador de calor externo a água 
Uma vez montados os trocadores de calor externos, foram efetuadas adaptações nos trocadores de calor internos para fixação e garantia de contato perfeito entre as superfícies dos trocadores de calor internos e externos com os módulos Peltier. Essas modificações, mostradas na figura 16, consistiram na perfuração da base dos trocadores de calor internos em 4 novos pontos $(A)$, além da furação original (B) do dissipador (C). Nesses 4 novos orifícios foram torneadas (D) roscas de $3 \mathrm{~mm}$ de diâmetro.

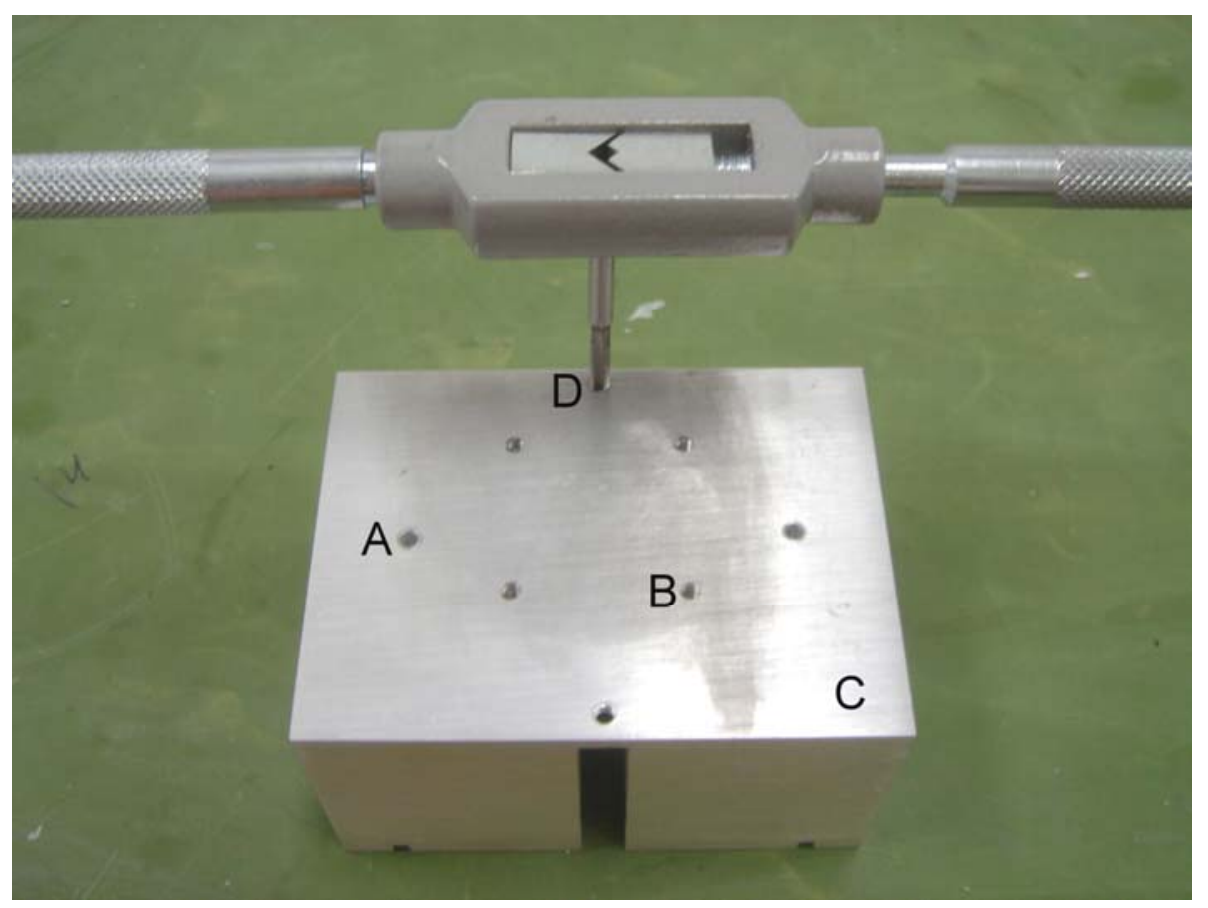

Figura 16 - Adaptação do trocador de calor interno 
Efetuadas essas adaptações, passou-se à montagem dos módulos Peltier e seus trocadores de calor internos na gincana de PVC, já revestida com isopor. A figura 17 mostra o início desta etapa. Notar: (A) - Segmento da gincana de PVC; (B) - Revestimento de isopor; (C) - Parafuso de fixação; (D) - Módulo Peltier já untado com pasta térmica para otimizar a superfície de contato entre materiais; $(E)$ - Perfil de borracha para intertravamento dos conjuntos de condicionamento e $(F)$ - Cabos de alimentação de corrente contínua do módulo Peltier.

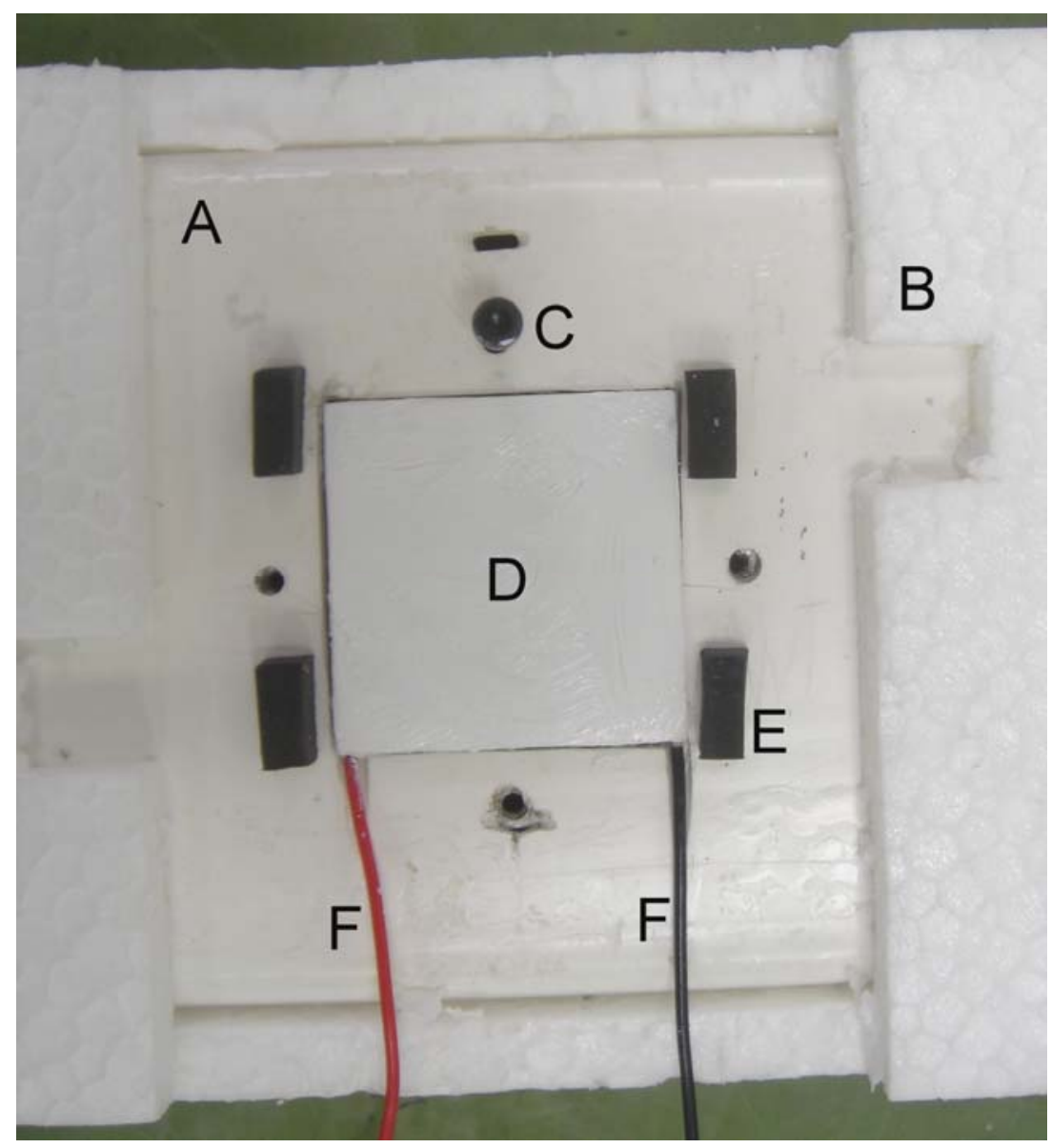

Figura 17 - Módulo Peltier e seu trocador de calor interno na gincana de PVC 
Concluída a montagem do trocador de calor interno, foram montados os trocadores de calor externos, como pode ser visto na figura 18. Para esta montagem, concluiu-se ser necessário uma isolação plástica $(A)$ entre os parafusos de fixação e o trocador de calor externo, visto que estes elementos irão trabalhar em temperaturas muito diferentes o que poderia diminuir a eficiência do conjunto de condicionamento. Em (B) nota-se o trocador de calor externo a água, em (C) o módulo Peltier, ainda afastado do trocador de calor externo, e em (D) o segmento da gincana de PVC revestida por isopor.

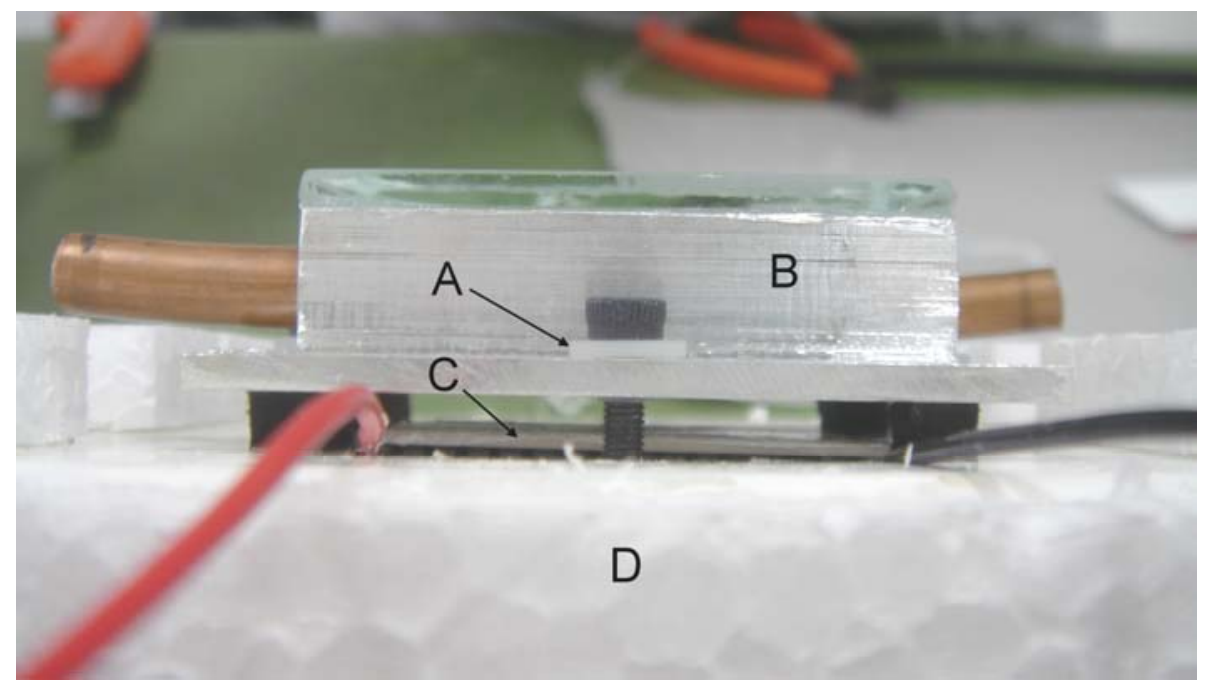

Figura 18 - Montagem final do dissipador a água

A figura 19 mostra uma visão panorâmica de todo o sistema de condicionamento montado e pronto para os próximos testes. Notar em (A) o microventilador a ser utilizado, que capta o ar externo e o conduz para o interior do sistema. Em (B) os termômetros, com sua escala de leitura posicionada de forma a permitir a coleta de dados diretamente. Os termômetros foram intercalados entre os módulos de condicionamento. O primeiro termômetro (T1), próximo ao ventilador, registrará a temperatura ambiente. Do segundo ao décimo primeiro termômetros serão registradas as temperaturas ao longo da gincana de condicionamento. E o décimo segundo (T12) a temperatura do ar de saída. Em (C) a rede de tubulação de água. Para o presente ensaio a água foi captada da rede hidráulica do prédio e conduzida para o sistema numa vazão de 1 litro por minuto. 


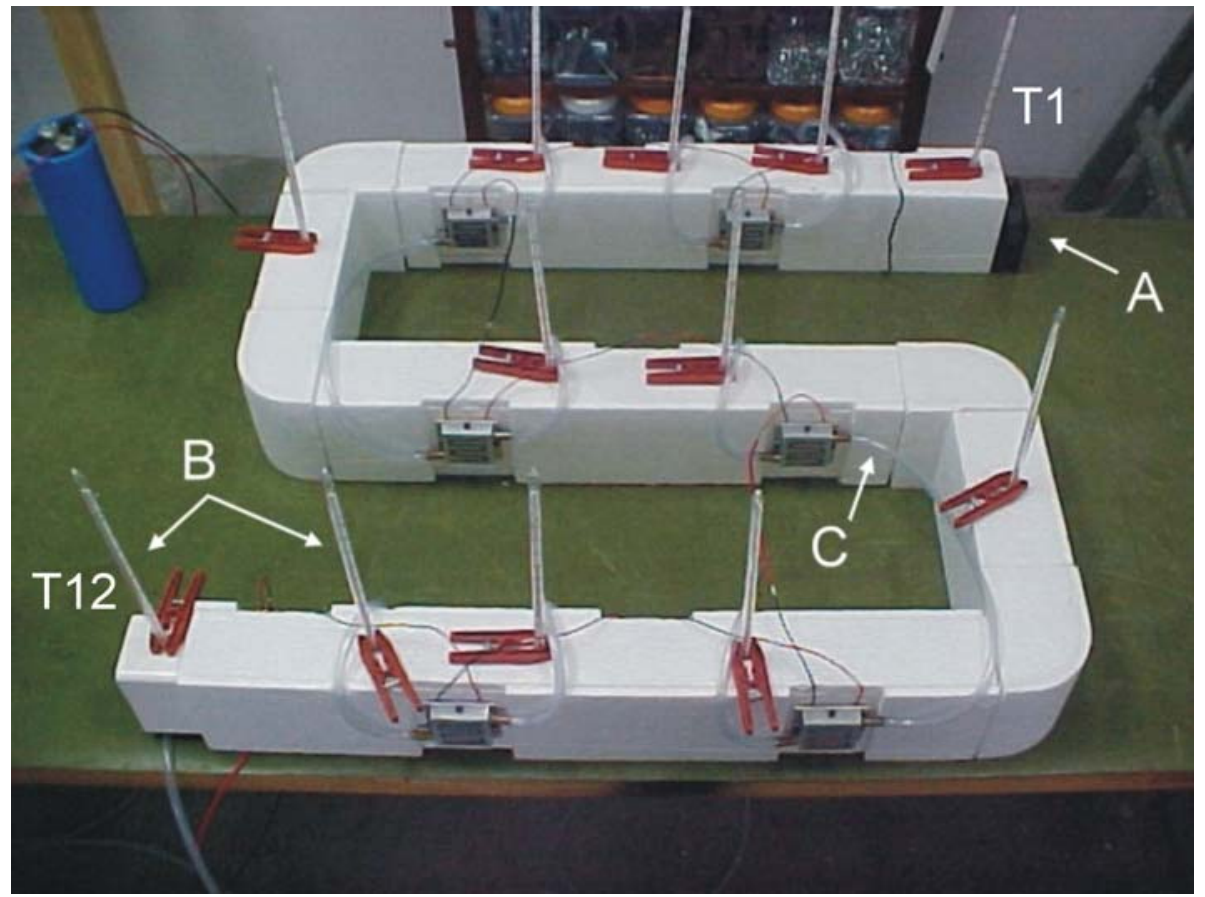

Figura 19 - Visão panorâmica da gincana de condicionamento

\subsubsection{Condicionador Tipo Retilíneo com Dissipação Externa a Água}

O condicionador tipo retilíneo com dissipação externa a água é formado pelo condicionador microambiental de ar (CM) e a caixa de isolamento térmico (CIT), no interior da qual realizou-se os testes com animais. 
4.1.2.4.1 Condicionador Microambiental (CM)

Para os testes com animais o $\mathrm{CM}$ foi montado de forma retilínea como ilustrado na figura 20.

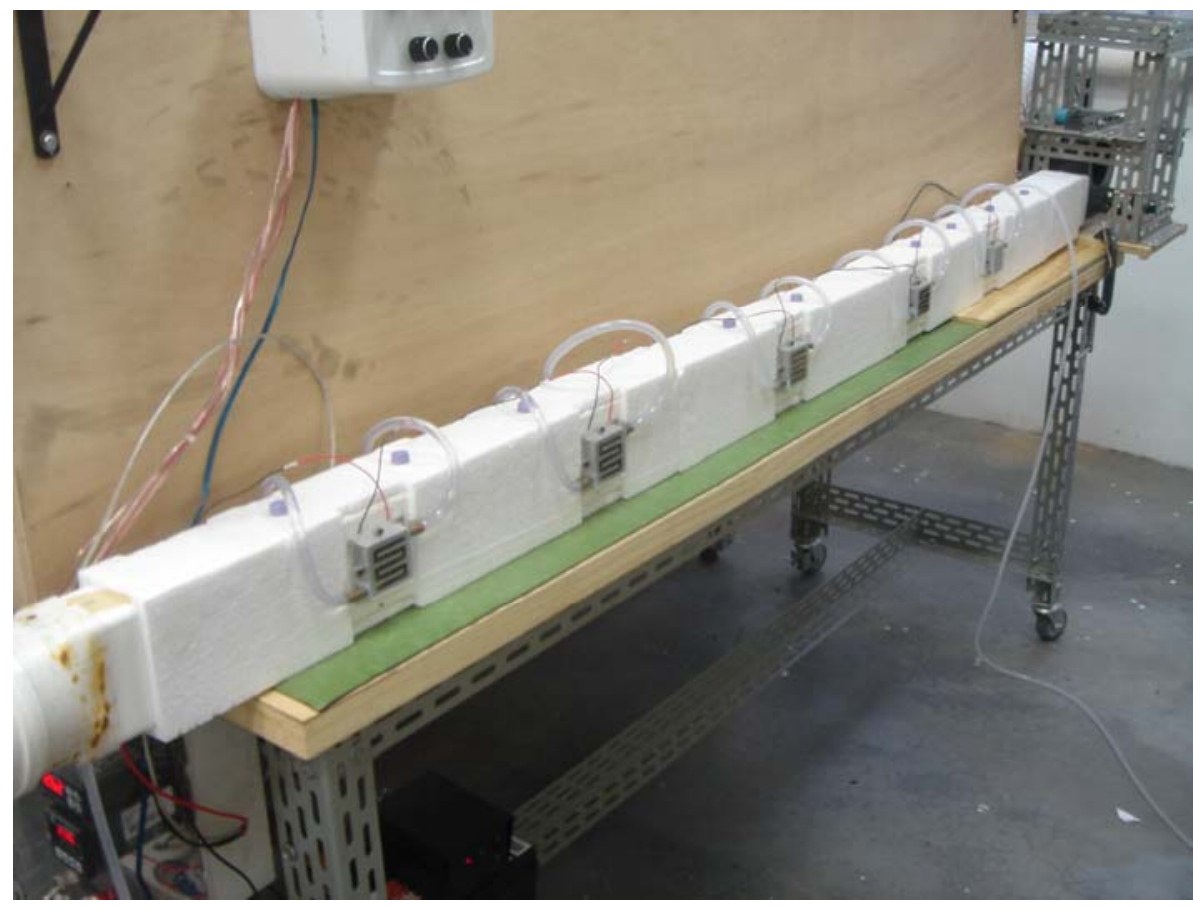

Figura 20 - Condicionador microambiental retilíneo 
Cada módulo termoelétrico foi montado em dissipadores a água. No total 11 módulos foram montados de forma serial tanto no que tange à alimentação dos módulos, quanto à disposição física ao longo da gincana de condicionamento de ar. A figura 21 ilustra em detalhes o módulo semicondutor neste condicionador.

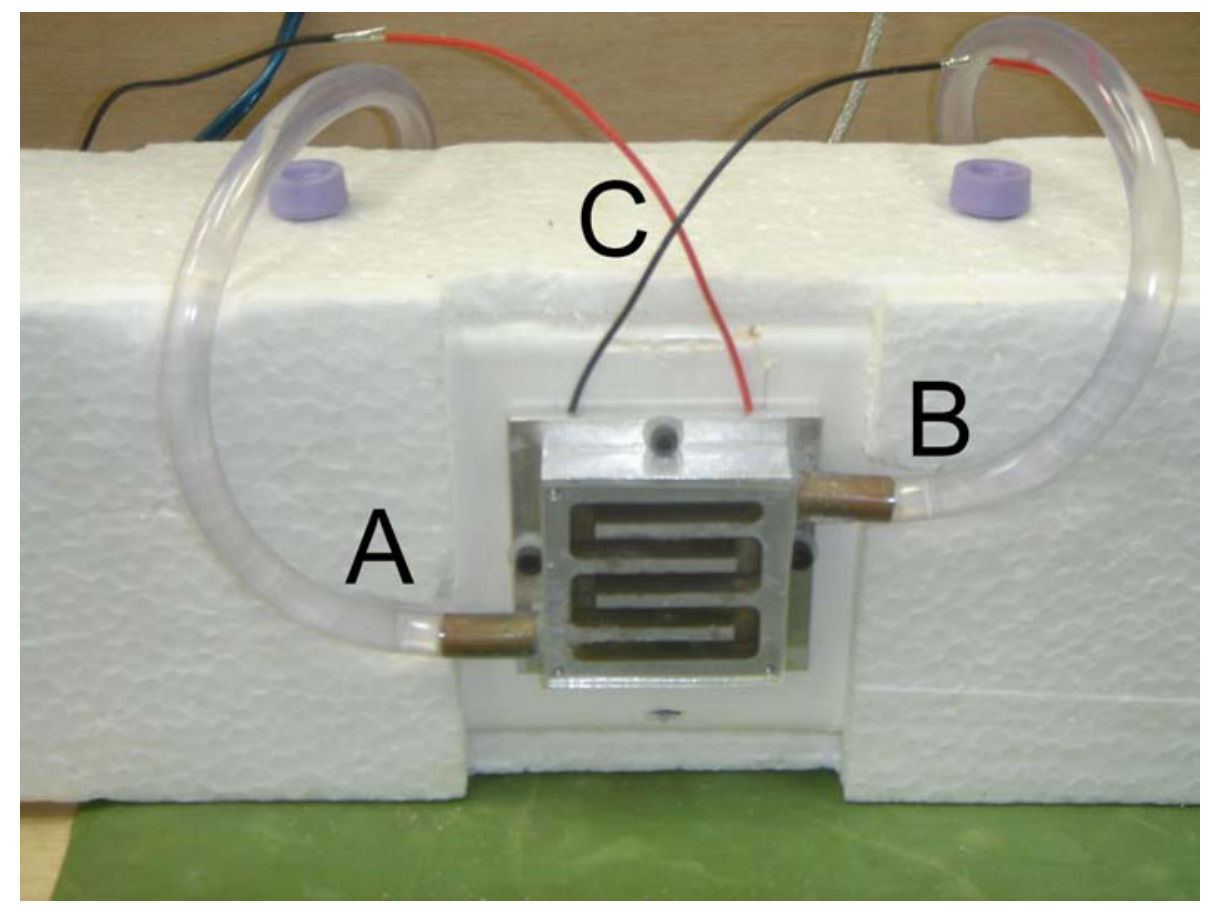

Figura 21 - Módulo de condicionamento térmico. Notar em (A) Entrada de água de arrefecimento; (B) Saída de água de arrefecimento e (C) Alimentação do módulo termoelétrico 
Em uma das extremidades do CM foi acoplado um ventilador do tipo centrífugo (Figura 22), responsável pela movimentação do ar, o qual será condicionado pelo sistema e posteriormente será levado aos animais no interior da CIT.

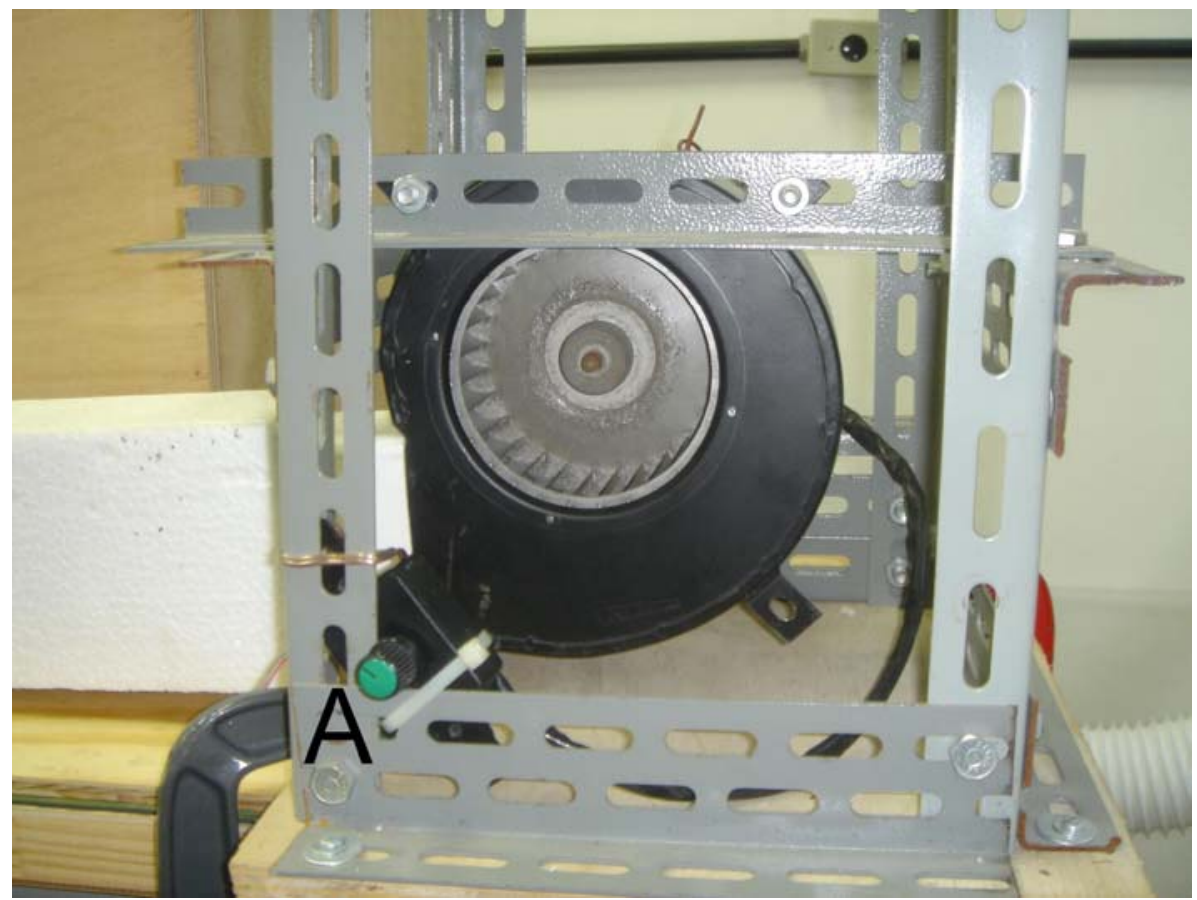

Figura 22 - Ventilador centrífugo. (A) Controlador de tensão

$\mathrm{Na}$ figura 22 (A) pode-se notar um controlador de tensão que é responsável pela modificação da rotação do ventilador. Com a variação da tensão de alimentação, podem-se obter diferentes velocidades de ar de insuflação que será conduzido até as gaiolas dos animais. 
4.1.2.4.2 Caixa de Isolamento Térmico (CIT)

Como os testes envolvem temperaturas diferentes da temperatura ambiental, a CIT (Figura 23) foi montada para manter as gaiolas em ambiente condicionado. Tendo em vista que os protocolos previam temperaturas internas da CIT não muito inferiores ou superiores que as do ambiente, optou-se pela madeira compensada como material de construção, por ser barato e possuir coeficiente de isolamento suficiente para manter o diferencial de temperatura. O compensado foi revestido internamente com fórmica para facilitar sua higienização.

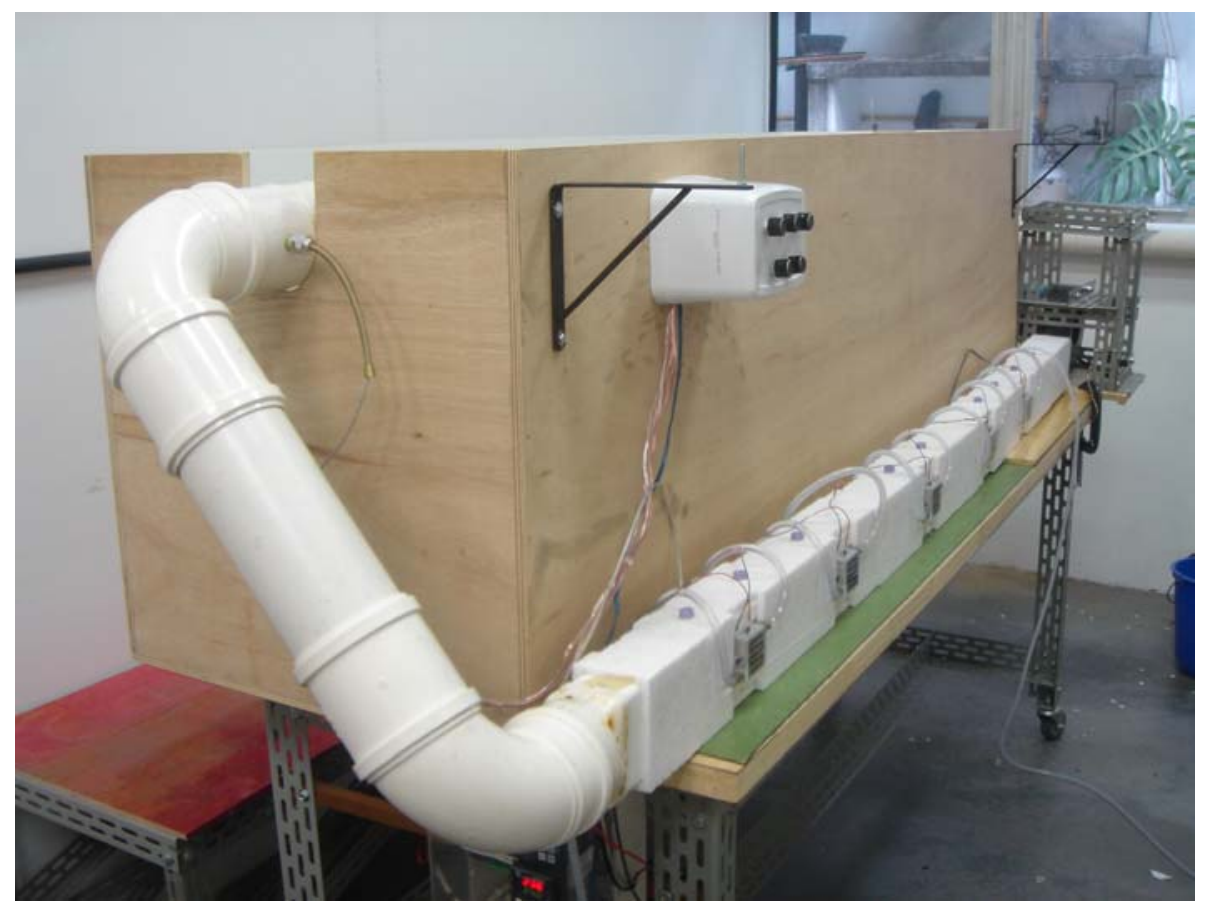

Figura 23 - Caixa de isolamento térmico (CIT) 
A parte superior da CIT foi provida de uma tampa em acrílico de $5 \mathrm{~mm}$ de espessura removível, para permitir a movimentação e limpeza das gaiolas metabólicas (Figura 24).

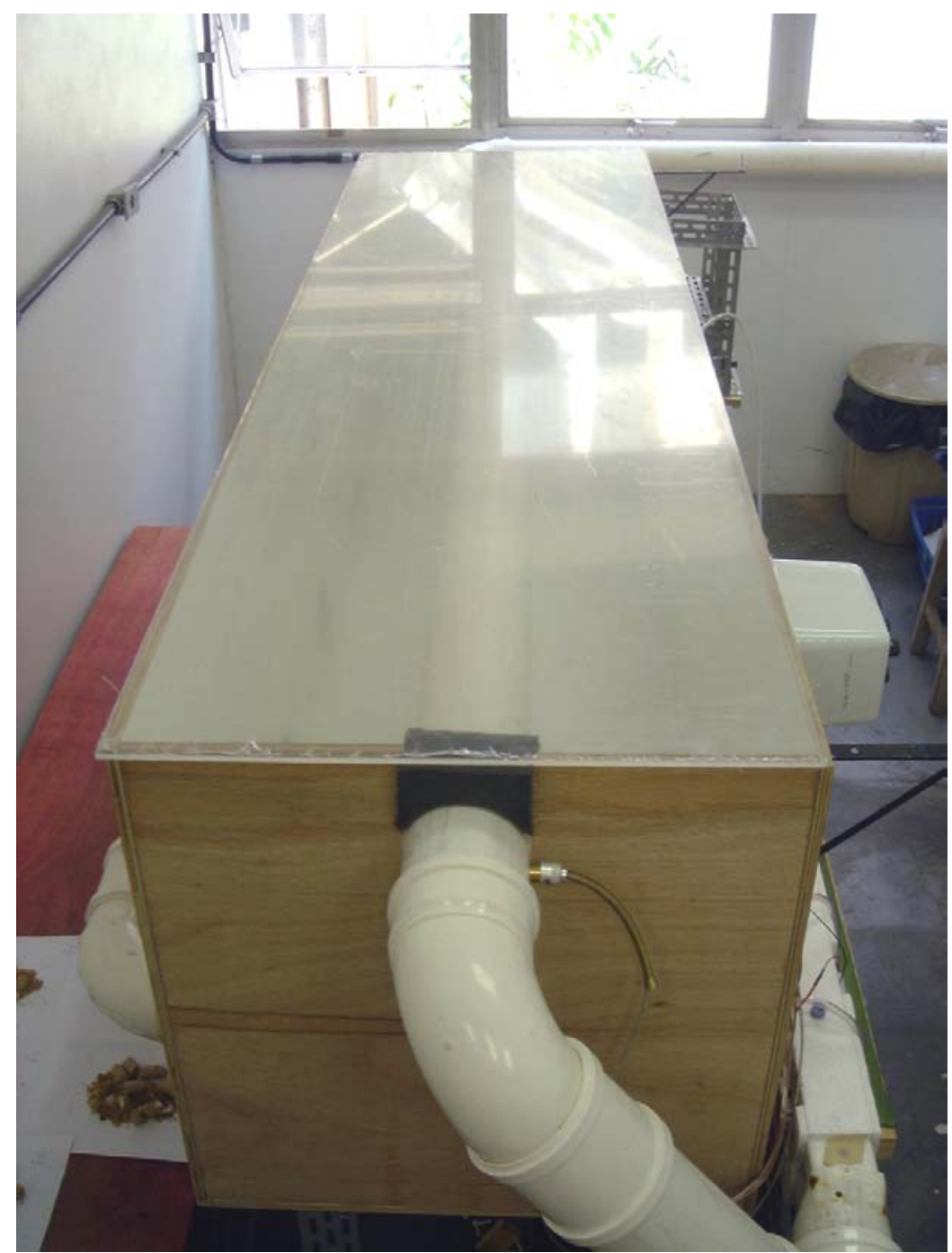

Figura 24 - Cobertura de acrílico removível 
No lado esquerdo inferior da CIT pode-se notar 5 orifícios, que são destinados à exaustão do ar que foi insuflado para o interior da CIT. Esses orifícios permitem a passagem do ar para a linha de exaustão situada na parte externa esquerda da CIT. Para facilitar as conexões e curvas, esta linha foi construída em 3 segmentos, dois deles rígidos e um flexível. Na Figura 25 pode ser visto o primeiro trecho rígido destinado a captar a massa de ar do interior da CIT. A figura 26 ilustra o segundo trecho, flexível, destinado a conduzir a massa de ar para o terceiro trecho de exaustão (Figura 27) que conduzirá essa massa para o exterior do recinto.

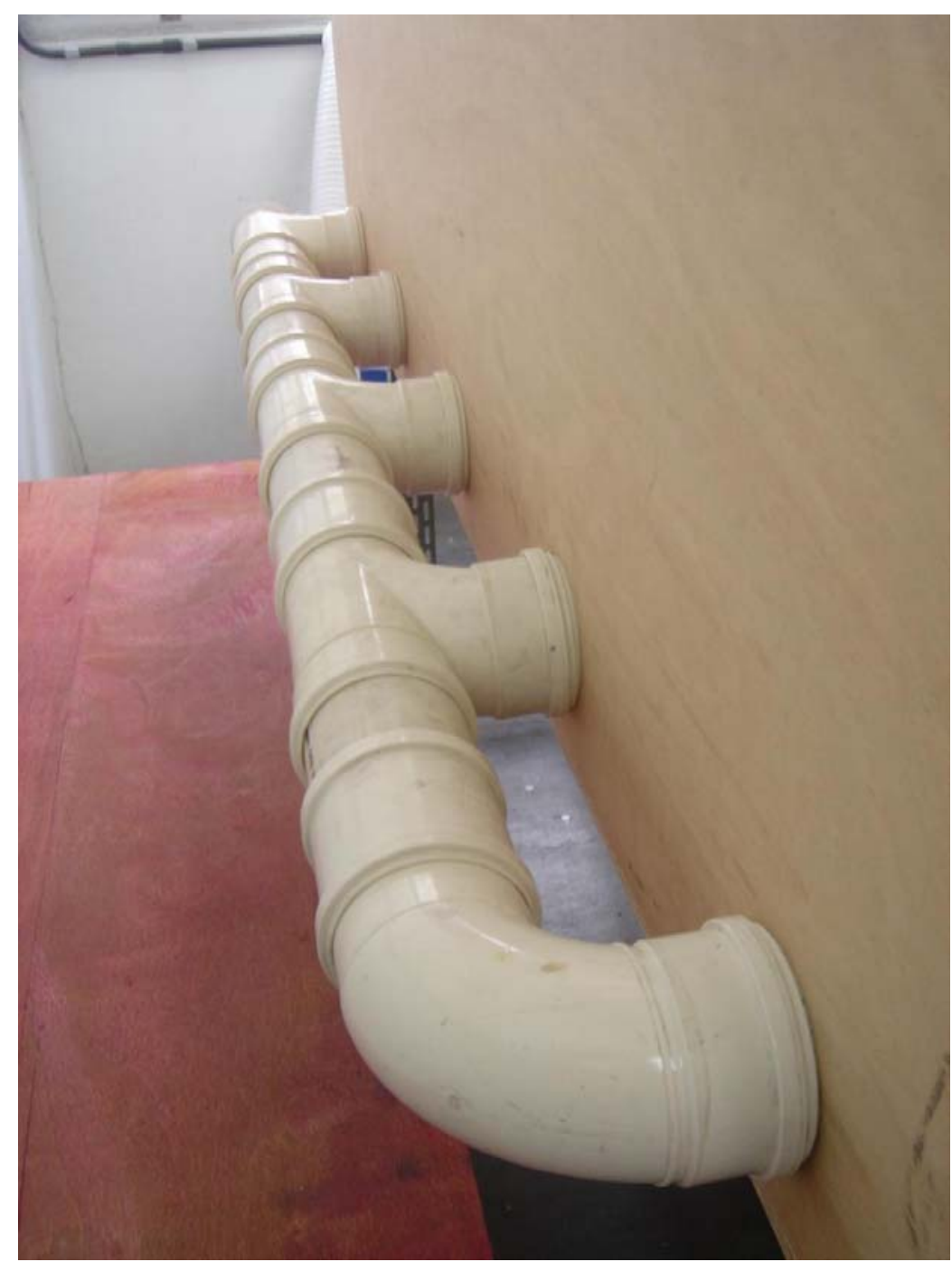

Figura 25 - Trecho rígido do duto de exaustão da CIT 


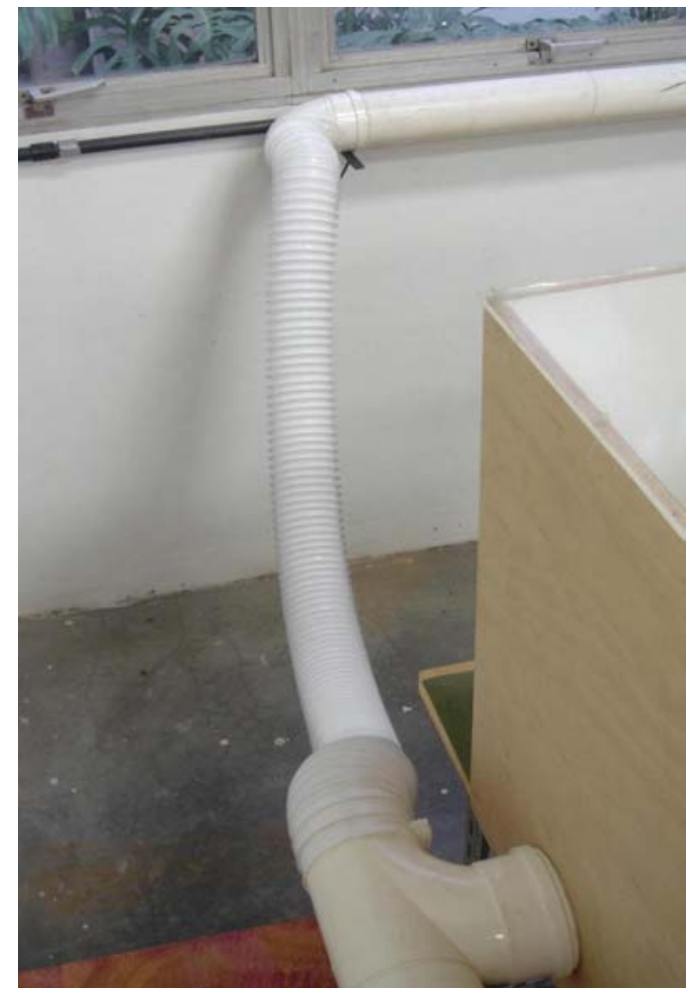

Figura 26 - Segundo trecho, flexível, da linha de exaustão

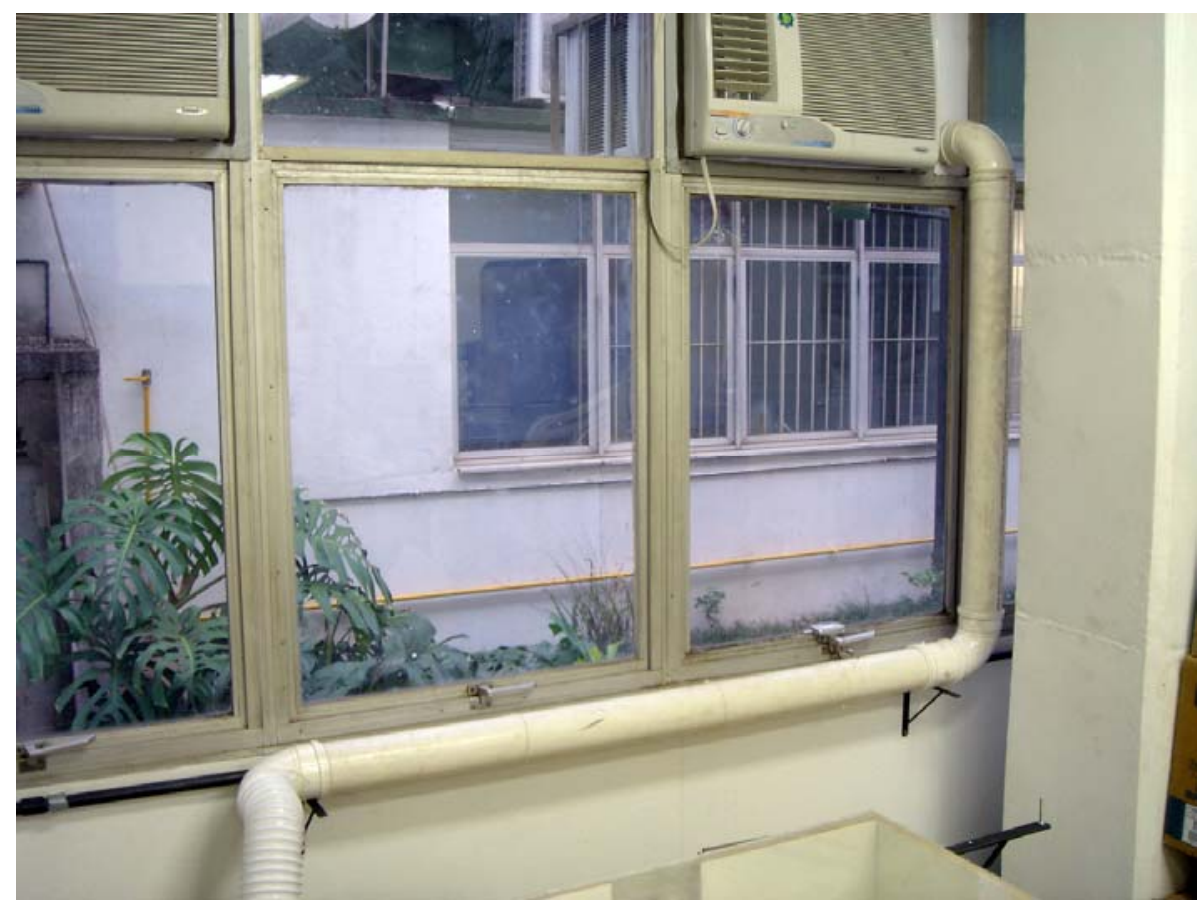

Figura 27 - Terceiro trecho, rígido, da linha de exaustão. Notar no ângulo superior direito da foto a descarga de ar do recinto para o exterior 
Pode-se notar que 0 ar, após ser condicionado pelos módulos termoelétricos, é direcionado para o interior da CIT. Em sua parte superior, a CIT possui um duto de insuflação de ar com 5 orifícios no seu semicirculo inferior, sendo um para cada gaiola metabólica (Figuras 28 e 29).

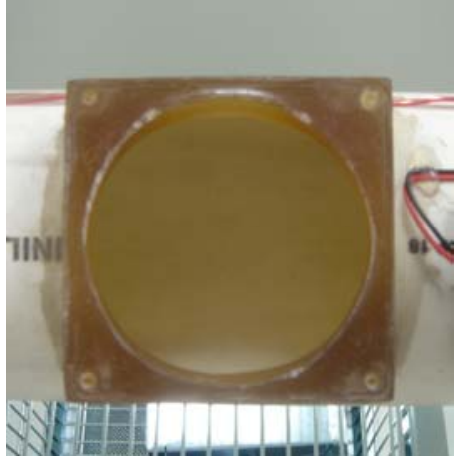

Figura 28 - Vista inferior da flange de insuflação

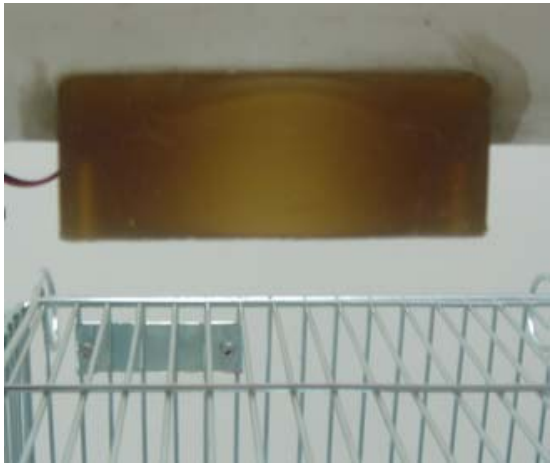

Figura 29 - Vista lateral da flange de insuflação

\subsection{Painel de Controle Elétrico da CIT}

Um controlador eletrônico digital microprocessado (CEDM) da marca COEL, modelo HW4900 (Figura 30), foi responsável pelo controle da temperatura da massa de ar insuflada para o interior da CIT, a qual passou pelos animais alojados nas gaiolas metabólicas. Este controlador, trabalhando em conjunto com 2 contatores (marca Telemecanique, modelo LC1D258M7) foram responsáveis pelo controle do fornecimento da corrente elétrica aos módulos termoelétricos. $A$ fonte de alimentação utilizada neste ensaio foi montada da mesma forma que a descrita nos ensaios anteriores. 


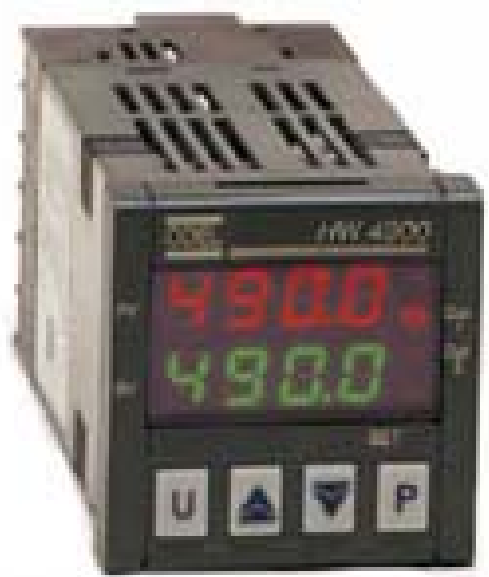

Figura 30 - Controlador eletrônico digital microprocessado

Quando em uso, é necessária a programação da temperatura desejada (temperatura de set point) para a massa ar que será condicionada. Esta temperatura deve ser informada pelo teclado do CEDM. Ao ser programado, o CEDM passa a monitorar um sensor de temperatura localizado no início do duto de ar, como ilustrado da figura 31.

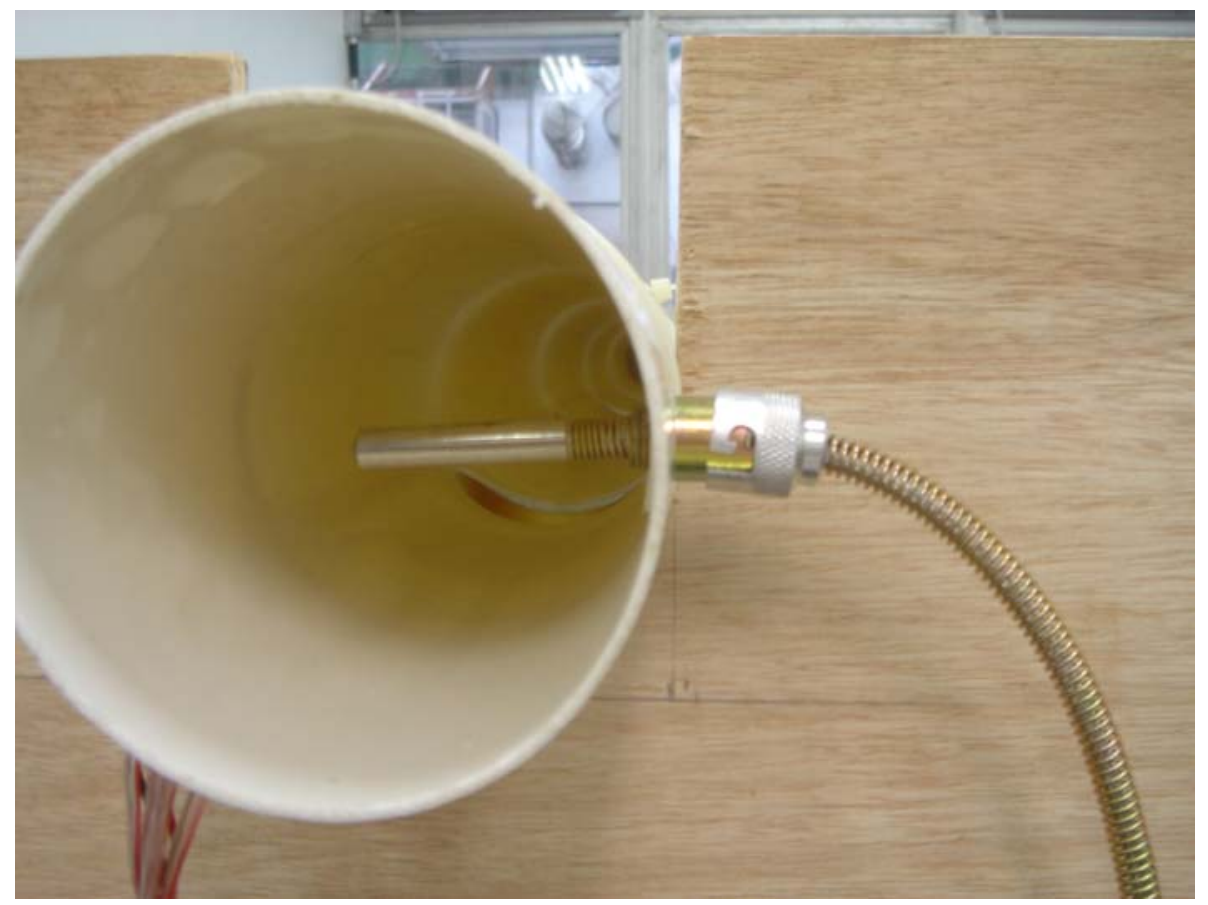

Figura 31 - Sensor de temperatura no duto de insuflação 
Após a leitura do sensor, o CEDM compara a temperatura de set point com a temperatura do ar que passou pelos módulos termoelétricos e aciona uma das suas duas saídas:

- Quando a temperatura de set point é inferior a temperatura do ar que passou pelo sistema de condicionamento, a saída 1 é acionada.

- Quando a temperatura de set point é superior a temperatura do ar que passou pelo sistema de condicionamento, a saída 2 é acionada.

Os contatores são acionados pelas saídas do CEDM e são responsáveis pelo gerenciamento da polaridade da tensão de alimentação dos módulos termoelétricos, de tal forma que um deles fornece energia para que o ar seja resfriado e o outro para que o ar seja aquecido:

- Quando a saída 1 estiver acionada, o sistema entende que deve resfriar o ar que será insuflado na CIT.

- Quando a saída 2 estiver acionada o sistema estará aquecendo o ar.

Desta forma, o sistema consegue manter a temperatura de set point com uma precisão de $\pm 0,1$ grau Celsius.

Em caso de falta de água de arrefecimento, um alarme foi montado utilizando um controlador eletrônico digital microprocessado para refrigeração (CE) (marca COEL, modelo TLZ12) - figura 32.

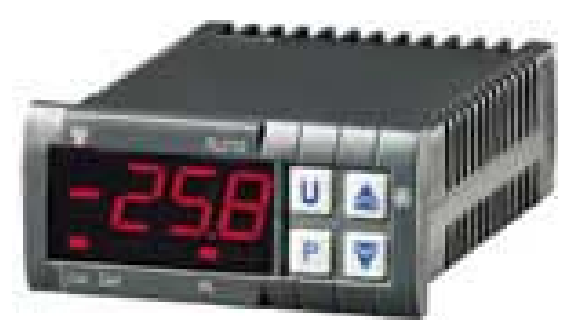

Figura 32 - Controlador Eletrônico (CE) modelo TLZ12 
O CE foi programado para que seja cortada a alimentação dos contatores quando a temperatura da água de arrefecimento alcançar níveis de segurança préprogramados. Para isso, um sensor de temperatura foi montado junto ao primeiro dissipador de calor a água, como ilustra a figura 33.

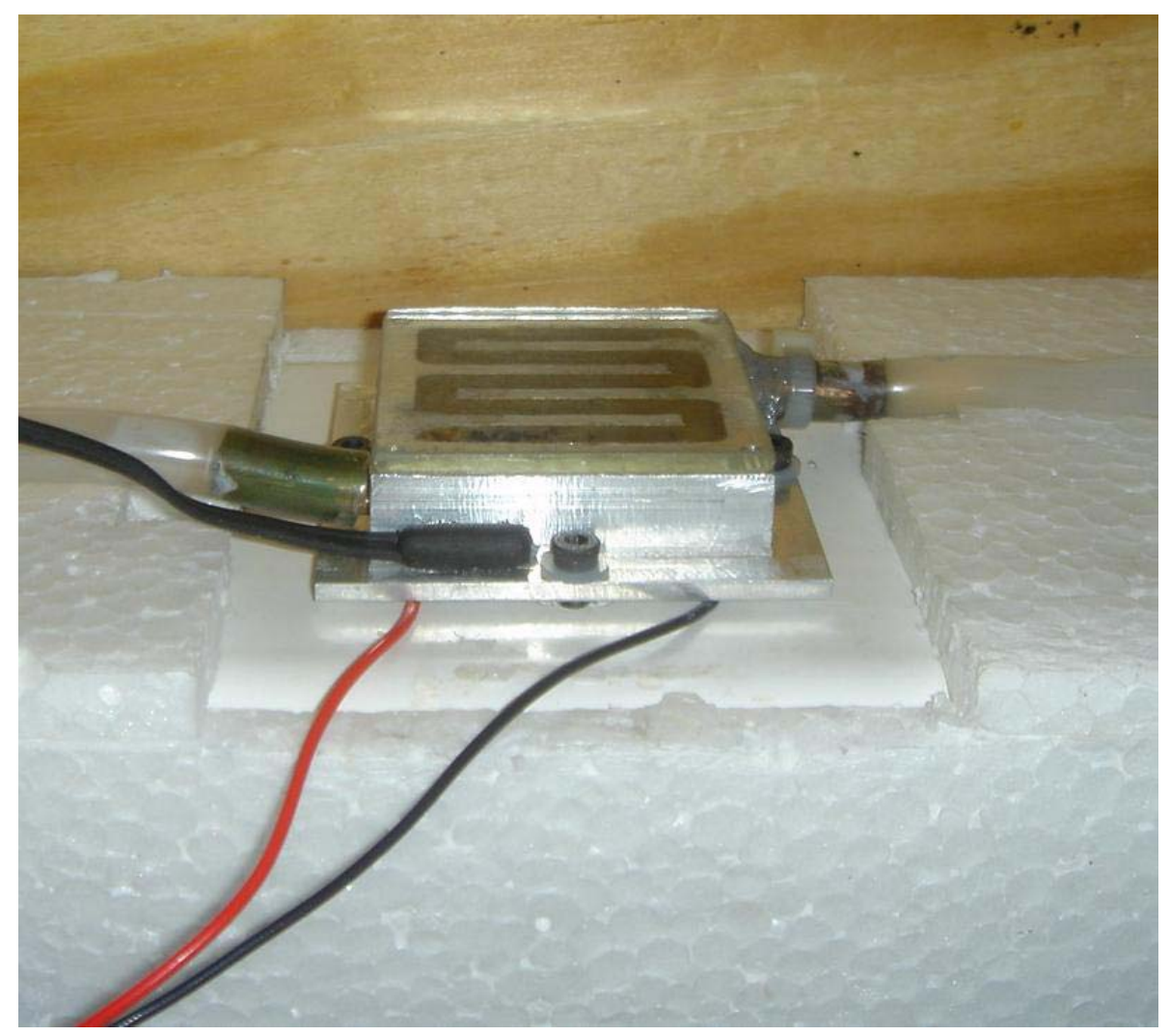

Figura 33 - Figura do sensor do CE

Quando as temperaturas, mínima ou máxima, são alcançadas o $\mathrm{CE}$ suspende a alimentação dos contatores de aquecimento e resfriamento, até que a temperatura do sensor de alarme assuma valores aceitáveis de segurança. As temperaturas mínima e máxima dependem diretamente da temperatura programada como "set point" no teclado do CE. Este equipamento, comumente utilizado em sistemas de condicionamento comercial, atua em uma escala de temperatura de "set point" entre $-58{ }^{\circ} \mathrm{C}$ e $302{ }^{\circ} \mathrm{C}$. No presente trabalho, foi escolhida uma faixa de temperatura de "set point" entre $20^{\circ} \mathrm{C}$ e $30^{\circ} \mathrm{C}$.

O "set point" pode ser considerado como um valor de temperatura de referência. Dessa forma, pode-se programar o equipamento para atuar numa escala 
acima ou abaixo deste valor, conforme a necessidade. Para este experimento, foi utilizada uma escala, com valor de temperatura normal de trabalho oscilando entre $15^{\circ} \mathrm{C} \mathrm{a}+15^{\circ} \mathrm{C}$ da temperatura "set point". Exemplificando, caso o "set point" seja de $25^{\circ} \mathrm{C}$, o alarme será ativado quando a temperatura do sensor da água de arrefecimento estiver menor que $10^{\circ} \mathrm{C}$ ou maior que $40^{\circ} \mathrm{C}$.

As causas de acionamento do alarme são atribuídas à falta ou à deficiência da passagem da água de arrefecimento pelos dissipadores dos módulos termoelétricos.

A figura 34 ilustra a montagem final do painel de controle elétrico da CIT. Em (A) nota-se o CEDM, em (B) o CE, em (C) o contator de controle de resfriamento, em (D) o contator de controle de aquecimento, em (E) a chave de acionamento do painel e em $(F)$ uma lâmpada piloto.

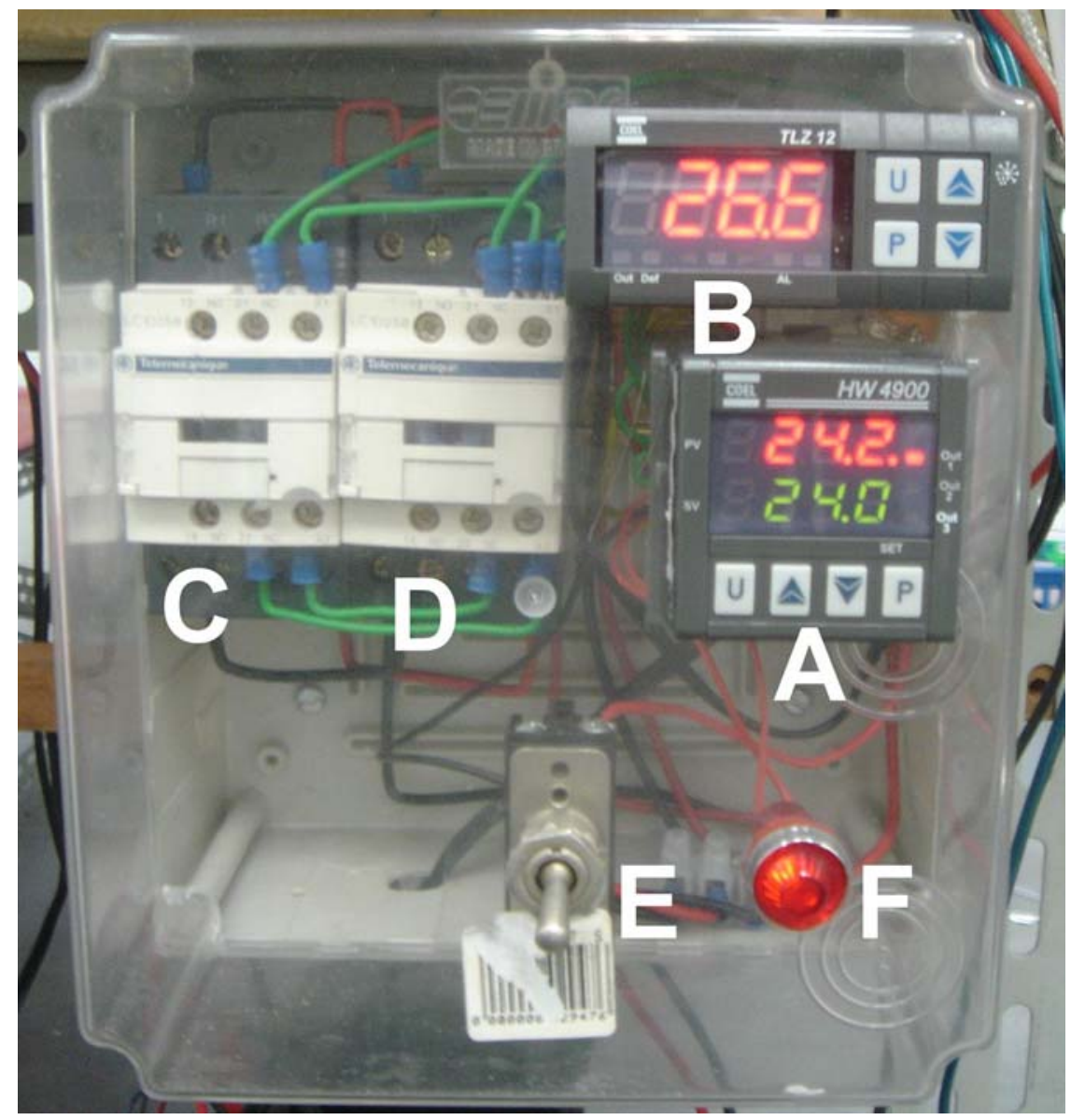

Figura 34 - Painel de controle elétrico 


\subsubsection{Teste de Rendimento dos Sistemas}

A atmosfera é composta por uma mistura de diversos gases, em percentuais aproximadamente constantes e vapor d'água, em quantidade extremamente variável, desde $0 \%$ (ar seco) até um máximo. Este máximo é a saturação, um estado de equilíbrio neutro entre o ar úmido e as fases condensadas da água (líquida ou sólida) (BEYER, 1993).

Dessa forma, tanto o ar atmosférico externo a um biotério quanto o ar condicionado constituem-se de mistura de ar mais vapor d'água, cujas propriedades físicas variam conforme a quantidade de vapor d'água, temperatura e pressão (altitude do local onde o biotério está edificado). Ao estudo da variação destas propriedades, denomina-se "psicrometria". As propriedades físicas do ar úmido estão indicadas num gráfico denominado "diagrama psicrométrico" (Anexo C).

As grandezas e as unidades utilizadas no diagrama psicrométrico são:

1. Temperatura de bulbo seco, TBS ou $\boldsymbol{t}\left({ }^{\circ} \mathrm{C}\right)$;

2. Temperatura de bulbo úmido, TBU ou $\boldsymbol{t}_{u}\left({ }^{0} \mathrm{C}\right)$;

3. Pressão parcial de vapor d'água, $\boldsymbol{p}_{v}(\mathbf{m m H g})$;

4. Umidade absoluta, $\boldsymbol{w}$ (kg/kg de ar seco);

5. Umidade relativa, $\psi(\%)$;

6. Volume específico, $v\left(\mathrm{~m}^{3} / \mathrm{kg}\right.$ de ar seco);

7. Ponto de orvalho $t_{o}\left({ }^{0} \mathrm{C}\right)$;

8. Entalpia, $\boldsymbol{i}$ (kcal ou kJ/kg de ar seco);

9. Grau de saturação, $\phi(\%)$;

10. Fator de calor sensível, FCS.

O diagrama psicrométrico permite que, conhecendo-se duas dessas grandezas, todas as demais sejam determinadas (YAMANE; SAITO, 1986).

No presente estudo, a massa de ar passou por um processo de condicionamento, portanto por um processo psicrométrico, o qual fez com que fossem modificadas todas as dez grandezas acima citadas, para a massa de ar tratado. Entretanto, visto ser necessário neste ensaio, apenas a determinação da entalpia ( $i$ ), foram utilizadas a medidas de TBS e TBU da massa de ar antes e após 
passar pelo tratamento. O diagrama psicrométrico por nós utilizado expressava a entalpia em quilojoules $(\mathrm{kJ})$.

Para melhor ilustrar os resultados e, estando o diagrama psicrométrico disponibilizado integralmente no anexo C, optou-se por apresentar, no corpo do texto, apenas os trechos do diagrama que contivessem as condições iniciais e finais da massa de ar, bem como da entalpia, para cada resultado obtido.

Entende-se por entalpia, a quantidade de energia da massa (ENTALPIA, 2007). Assim, determinada massa de ar, a uma determinada temperatura, terá uma entalpia i e uma massa de ar de volume 10 vezes maior, à mesma temperatura, terá uma entalpia $10 \times i$.

No presente estudo, a determinação da entalpia mostra-se relevante por permitir a determinação e comparação do rendimento dos sistemas de resfriamento a ar e a água.

Por rendimento, entende-se a quantidade de trabalho executado por uma máquina ou sistema, em função da energia fornecida. A energia fornecida é a potência total $\left(P_{T}\right)$ e a quantidade de trabalho executado é a potencia útil $\left(P_{U}\right)$. Em sistemas teóricos denominados ideais, $\mathrm{P}_{\mathrm{T}}=\mathrm{P}_{\mathrm{U}}$. Na prática, porém, sempre ocorrem perdas na execução de um trabalho e portanto $\mathrm{P}_{\mathrm{T}}>\mathrm{P}_{\mathrm{U}}$. A diferença entre essas duas potências é a chamada potência dissipada $\left(P_{D}\right)$, perdida sob forma de outras energias. Em virtude do princípio da conservação de energia tem-se então:

$$
\mathbf{P}_{\mathbf{T}}=\mathbf{P}_{\mathbf{U}}+\mathbf{P}_{\mathbf{D}(1)}
$$

Como rendimento $\eta$, define-se a relação entre a $\mathrm{P}_{\cup}$ e a $\mathrm{P}_{\mathrm{T}}$ :

$$
\eta=\mathbf{P}_{\mathbf{U}} / \mathbf{P}_{\mathbf{T}}(2)
$$

O rendimento $\eta$ é um número adimensional (PELEGRINI, 1997).

Visto que o rendimento $\eta$ é um número puro, ou seja, não é associado a nenhuma grandeza métrica, pode-se, também, traduzir este rendimento $\eta$ em termos percentuais. Neste caso, $\eta$ pode ser quantificado percentualmente, numa relação entre grandezas da seguinte forma: 


\section{$\eta=\left(P_{\mathbf{U}} \times 100\right) / P_{T}(3)$}

Considera-se essa forma mais compreensível por manter uma unidade de relação entre grandezas e associada a $\eta(\%)$, uma vez que o número puro é, às vezes, de difícil interpretação. Além disso, essa fórmula traduz, mais claramente, o quanto foi fornecido de energia e o quanto desta energia foi transformada em trabalho pelo sistema.

No presente estudo, $\mathrm{P}_{\mathrm{T}}$ é a energia elétrica consumida pelos módulos Peltier e $\mathrm{Pu}_{\mathrm{u}}$ a quantidade de calor retirado por esses módulos, da massa de ar tratado, ou seja, a diferença entre a entalpia inicial da massa de ar (ar captado do ambiente) e sua entalpia final (ar condicionado).

\subsubsection{Comparação de Custo de Implantação por BTU Gerado}

Para a comparação de custos torna-se necessária a utilização de uma unidade para o cálculo de desempenho térmico. Optou-se pela British Thermal Unit (Unidade Térmica Britânica, BTU), utilizada na Inglaterra, Estados Unidos e ainda muito utilizada no Brasil, embora haja uma tendência de sua substituição por uma unidade métrica, a quilocaloria (kcal). Na prática do dia-a-dia, porém, a unidade BTU é uma das mais utilizadas pelos projetistas. Em qualquer sistema térmico esta unidade expressa a quantidade de calor trocado, rejeitado ou ganho, pelo sistema para o ambiente, servindo dessa forma para dimensionar o equipamento. Para maior clareza, efetuou-se a comparação de custos em termos de BTU entre o sistema termoelétrico proposto e um sistema que opera via ciclo de compressão do freon, instalado no final do ano de 2006 em um dos biotérios do Departamento de Patologia da Faculdade de Medicina Veterinária e Zootecnia da Universidade de São Paulo (processo RUSP n 2006.1.352.826). 


\subsection{ENSAIOS COM ANIMAIS}

Fase destinada especificamente ao uso de animais. Visando obter e avaliar os resultados do equipamento projetado.

\subsubsection{Animais}

Foram utilizados 105 ratos Wistar (Rattus norvegicus), padrão sanitário convencional controlado, machos com 45 dias, provenientes do biotério do Departamento de Patologia - FMVZ/USP.

\subsubsection{Número de Animais}

Foram utilizados 15 animais por grupo num total de 7 grupos, sendo 2 grupos de controle e 5 experimentais. Os grupos experimentais E I, E II, E III, E IV e E V foram mantidos sob temperaturas de $22^{\circ}, 24^{\circ}, 26^{\circ}, 28^{\circ}$ e $30^{\circ} \mathrm{C}$, respectivamente, com variação máxima de $\pm 0,1^{\circ} \mathrm{C}$. Os dois grupos controle, C I e C II, foram mantidos a $22^{\circ} \mathrm{C}$, sendo que $\mathrm{C}$ I foi mantido sob condições ambientais semelhantes a biotérios convencionais sob ventilação geral diluidora (VGD $22 \pm 2^{\circ} \mathrm{C}$ ) como prevista em literatura (CCAC, 1980). C II foi mantido no interior do equipamento de ventilação microambiental mas sem o direcionamento de ar sobre as gaiolas, mantendo as trocas de calor semelhantes as encontradas em biotérios convencionais simulando a VGD, a $22 \pm 0,1^{\circ} \mathrm{C}$.

Tendo em vista o fato de que nenhuma inoculação experimental foi realizada e que os animais não foram submetidos a qualquer situação estressante, os mesmos puderam ser fornecidos a outros pesquisadores posteriormente. 


\subsubsection{Gaiolas Metabólicas}

No interior da CIT foram mantidas 5 gaiolas metabólicas (Marca Beiramar ${ }^{4}$ - Modelo MA 121) . Em cada gaiola metabólica foi alojado um animal. Estas gaiolas permitem controlar a quantidade de ração e água consumidas e coletar, separadamente, as fezes e a urina provenientes do metabolismo animal. Na figura 35 pode-se visualizar em detalhes a gaiola metabólica utilizada neste ensaio com animais.

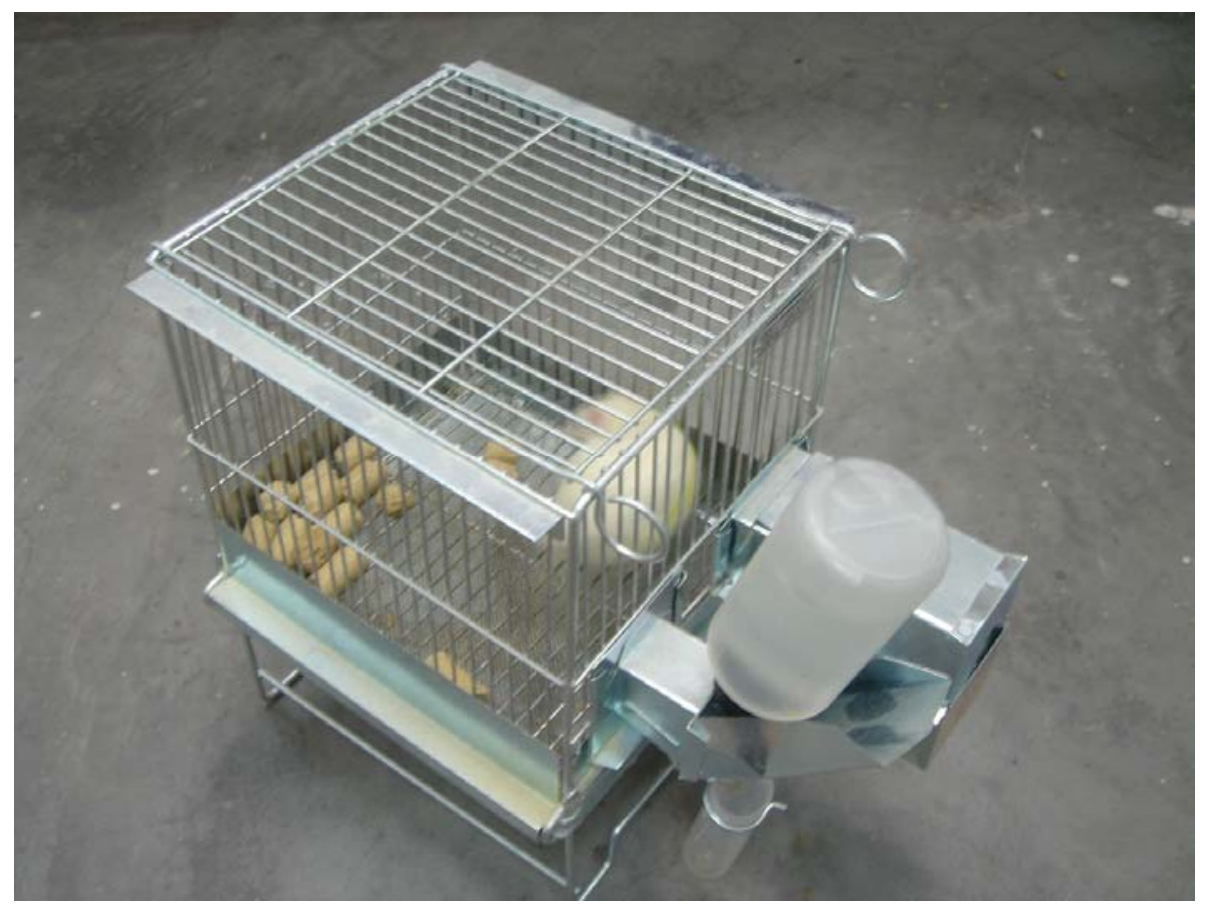

Figura 35 - Gaiola metabólica

\footnotetext{
${ }^{4}$ Beiramar Indústria e Comércio Ltda.

Rua Capitão Otávio Machado, $n^{\circ} 662$, Chácara Sto. Antônio, São Paulo CEP: 04718-001 - SP
} 
A figura 36 ilustra as 5 gaiolas metabólicas dispostas no interior da CIT diretamente abaixo dos orifícios de insuflação.

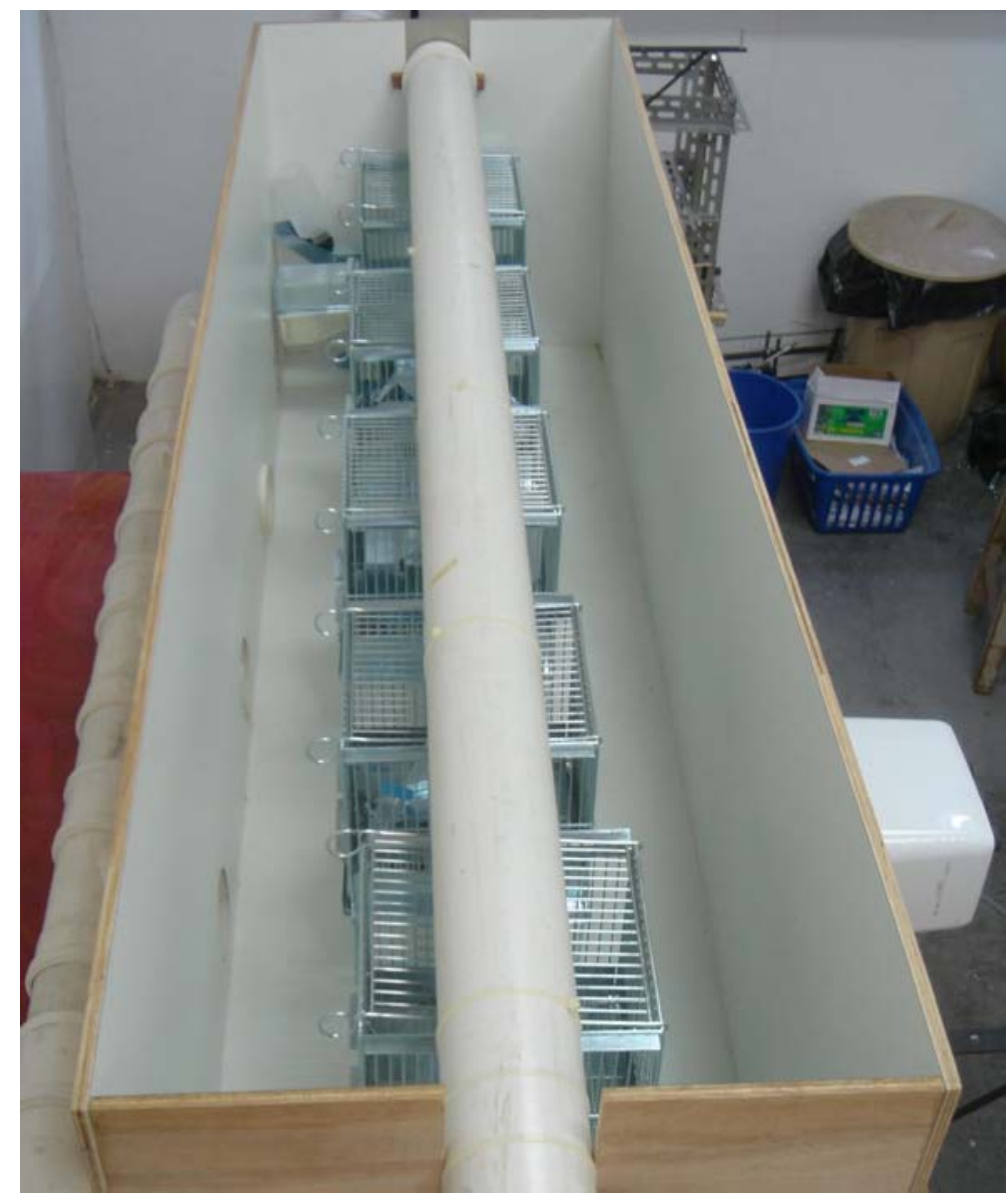

Figura 36 - Gaiolas metabólicas no interior da CIT

\subsubsection{Ração}

Foi utilizada ração comercial, para ratos e camundongos, marca NUVITAL ${ }^{5}$. No sentido de minimizar eventuais influências de diferentes formulações, foi fornecida para os grupos sempre ração proveniente do mesmo lote.

\footnotetext{
${ }^{5}$ Nuvital Nutrientes S/A

Estrada da Ribeira, 3001 km 3 - Alto Maracanã - Colombo - PR
} 


\subsection{3 Água}

Os animais de ambos os grupos, experimental e controle, receberam água ad libtum em frascos bebedouros preparados no próprio biotério.

\subsubsection{Análise Estatística}

Os resultados obtidos dos experimentos foram analisados comparando-se as médias obtidas dos grupos controles e experimentais. O Teste ANOVA - TukeyKramer foi utilizado para verificar as diferenças entre a ingestão de ração e o ganho de peso dos diferentes grupos.

\subsubsection{Delineamento Experimental}

O sistema de condicionamento utilizado foi gerenciado eletronicamente via controlador eletrônico digital microprocessado $\left(\mathrm{COEL}^{\circledR}\right)$, que modulava a corrente elétrica de alimentação através de contatores (Telemecanique ${ }^{\circledR}$ ), o que permitiu variação máxima de $\pm 0,1^{\circ} \mathrm{C}$ da temperatura experimental. As gaiolas metabólicas foram mantidas no interior de uma caixa de isolamento térmico (CIT) em madeira $\left(\mathrm{W} / \mathrm{m}{ }^{\circ} \mathrm{C} \cong 0,17\right)$, com capacidade para 5 gaiolas metabólicas com direcionamento direto do ar, a uma velocidade aproximada de 0,6 m/s, sobre as mesmas. Esta passagem de ar forçada sobre os animais, provoca uma troca de calor mais intensa entre o animal e o ambiente.

Em cada gaiola metabólica foi alojado um animal. Estas gaiolas permitem controlar a quantidade de ração e água consumidas e coletar, separadamente, as fezes e a urina provenientes do metabolismo animal.

Para cada temperatura foram separados 3 lotes, de 5 animais cada, mantidos na CIT por 5 dias. Ao final do $15^{\circ}$ dia, a temperatura era modificada para a próxima temperatura experimental. 
A ração foi colocada no primeiro dia de experimento (aproximadamente 100 gramas) para cada animal. No terceiro dia, a sobra foi retirada e deixada para secar à temperatura ambiente por 48 horas. Ainda no terceiro dia, outra porção de ração foi colocada e a respectiva sobra retirada no quinto e último dia, repetindo-se o procedimento de secagem. A ingestão de ração foi calculada pela soma das duas porções oferecidas aos animais subtraindo-se as respectivas sobras secas. Este procedimento de cálculo foi adotado para todos lotes de 5 animais, sempre ao final de cada período de 5 dias. 


\subsection{DESEMPENHO DO CONDICIONADOR TIPO GINCANA COM DISSIPAÇÃO EXTERNA A AR}

A tabela 1 mostra a queda de temperatura ao longo do sistema de condicionamento com dissipação externa a ar logo após o início do ensaio, a tabela 2 após 20 minutos de operação do sistema com as temperaturas já estabilizadas.

Tabela 1 - Temperaturas $\left({ }^{\circ} \mathrm{C}\right)$ dos 12 termômetros no sistema de condicionamento tipo gincana com dissipação externa a ar, durante as 21 séries de medições. Condições elétricas de operação: tensão de alimentação de 15 volts por semicondutor, consumo total de 7,35 amperes e potência de 1212,75 watts por hora. Velocidade do ar condicionado de $1 \mathrm{~m} / \mathrm{s}$ e vazão de 5,82 litros por segundo - São Paulo - 2005

Termômetros

\begin{tabular}{ccccccccccccc}
\hline Série $^{*}$ & 1 & 2 & 3 & 4 & 5 & 6 & 7 & 8 & 9 & 10 & 11 & 12 \\
\hline 1 & 21 & 21 & 21 & 21 & 21 & 21 & 21 & 21 & 21 & 21 & 21 & 21 \\
2 & 20 & 21 & 21 & 21 & 21 & 21 & 21 & 21 & 21 & 21 & 21 & 21 \\
3 & 20 & 21 & 21 & 21 & 21 & 21 & 21 & 21 & 21 & 21 & 21 & 20 \\
4 & 20 & 20 & 20 & 20 & 20 & 20 & 20 & 20 & 20 & 20 & 20 & 19 \\
5 & 20 & 20 & 20 & 20 & 20 & 20 & 20 & 20 & 20 & 19 & 19 & 19 \\
6 & 20 & 20 & 20 & 20 & 20 & 20 & 20 & 19 & 19 & 19 & 19 & 19 \\
7 & 21 & 20 & 19 & 19 & 19 & 19 & 18 & 19 & 18 & 18 & 18 & 19 \\
8 & 22 & 20 & 19 & 18 & 19 & 19 & 18 & 19 & 18 & 17 & 17 & 17 \\
9 & 22 & 20 & 19 & 18 & 18 & 18 & 18 & 18 & 17 & 16 & 16 & 16 \\
10 & 22 & 20 & 18 & 17 & 18 & 18 & 17 & 17 & 15 & 15 & 15 & 15 \\
11 & 22 & 20 & 18 & 16 & 18 & 17 & 16 & 17 & 15 & 15 & 15 & 15 \\
12 & 22 & 20 & 17 & 16 & 18 & 17 & 16 & 17 & 15 & 15 & 14 & 15 \\
13 & 23 & 20 & 17 & 16 & 18 & 17 & 16 & 17 & 15 & 15 & 14 & 14 \\
14 & 23 & 20 & 17 & 16 & 18 & 17 & 16 & 16 & 14 & 14 & 14 & 13 \\
15 & 23 & 20 & 17 & 16 & 18 & 17 & 16 & 16 & 14 & 14 & 13 & 13 \\
16 & 23 & 20 & 17 & 16 & 18 & 17 & 16 & 16 & 14 & 14 & 13 & 13 \\
17 & 23 & 20 & 17 & 16 & 18 & 17 & 15 & 16 & 14 & 13 & 13 & 13 \\
18 & 23 & 20 & 17 & 16 & 18 & 17 & 15 & 17 & 14 & 13 & 12 & 12 \\
19 & 24 & 20 & 18 & 17 & 18 & 17 & 16 & 17 & 14 & 13 & 12 & 12 \\
20 & 24 & 20 & 18 & 17 & 18 & 18 & 16 & 17 & 14 & 13 & 12 & 12 \\
21 & 25 & 21 & 18 & 16 & 18 & 18 & 16 & 17 & 14 & 13 & 12 & 12 \\
\hline \multirow{*}{*}{ Séris }
\end{tabular}

* Séries de tomadas de temperatura até a estabilização do sistema. Intervalos de tomadas de temperatura: 1 segundo entre cada termômetro e 12 segundos entre cada série. 
Tabela 2 - Temperaturas $\left({ }^{\circ} \mathrm{C}\right)$ dos 12 termômetros no sistema de condicionamento tipo gincana com dissipação externa a ar após 20 minutos do início do ensaio. Condições elétricas de operação: tensão de alimentação de 15 volts por semicondutor, consumo total de 7,35 amperes e potência de 1212,75 watts por hora. Velocidade do ar condicionado de $1 \mathrm{~m} / \mathrm{s}$ e vazão de 5,82 litros por segundo - São Paulo - 2005

\begin{tabular}{ccccccccccccc} 
& \multicolumn{11}{c}{ Termômetros } \\
\cline { 2 - 13 } & 1 & 2 & 3 & 4 & 5 & 6 & 7 & 8 & 9 & 10 & 11 & 12 \\
\hline Temperatura & 26 & 22 & 19 & 15 & 18 & 17 & 16 & 17 & 14 & 13 & 12 & 12 \\
\hline
\end{tabular}

As tabelas 1 e 2 mostram claramente a queda de temperatura do ar desde o início do ensaio até a estabilização do sistema. Um outro fenômeno também ficou caracterizado nas temperaturas registradas ao longo da gincana. Esse fenômeno se traduz por 2 picos distintos de elevação de temperatura, registrados nos termômetros 5 e 8 ("ilhas calor"), justamente os termômetros localizados no segmento médio das curvas da gincana. Isso mostra que ao passar pelas curvas o ar ganhou calor, diminuindo, nestes pontos, a eficiência do sistema. Ao decorrer de 20 minutos houve uma queda de temperatura de $14^{\circ} \mathrm{C}$.

Em sistemas de ar condicionado, além da temperatura, deve-se levar em consideração a entalpia envolvida. A variação de entalpia referente ao presente teste pode ser visualizada no segmento da carta psicrométrica (Figura 37 ). 


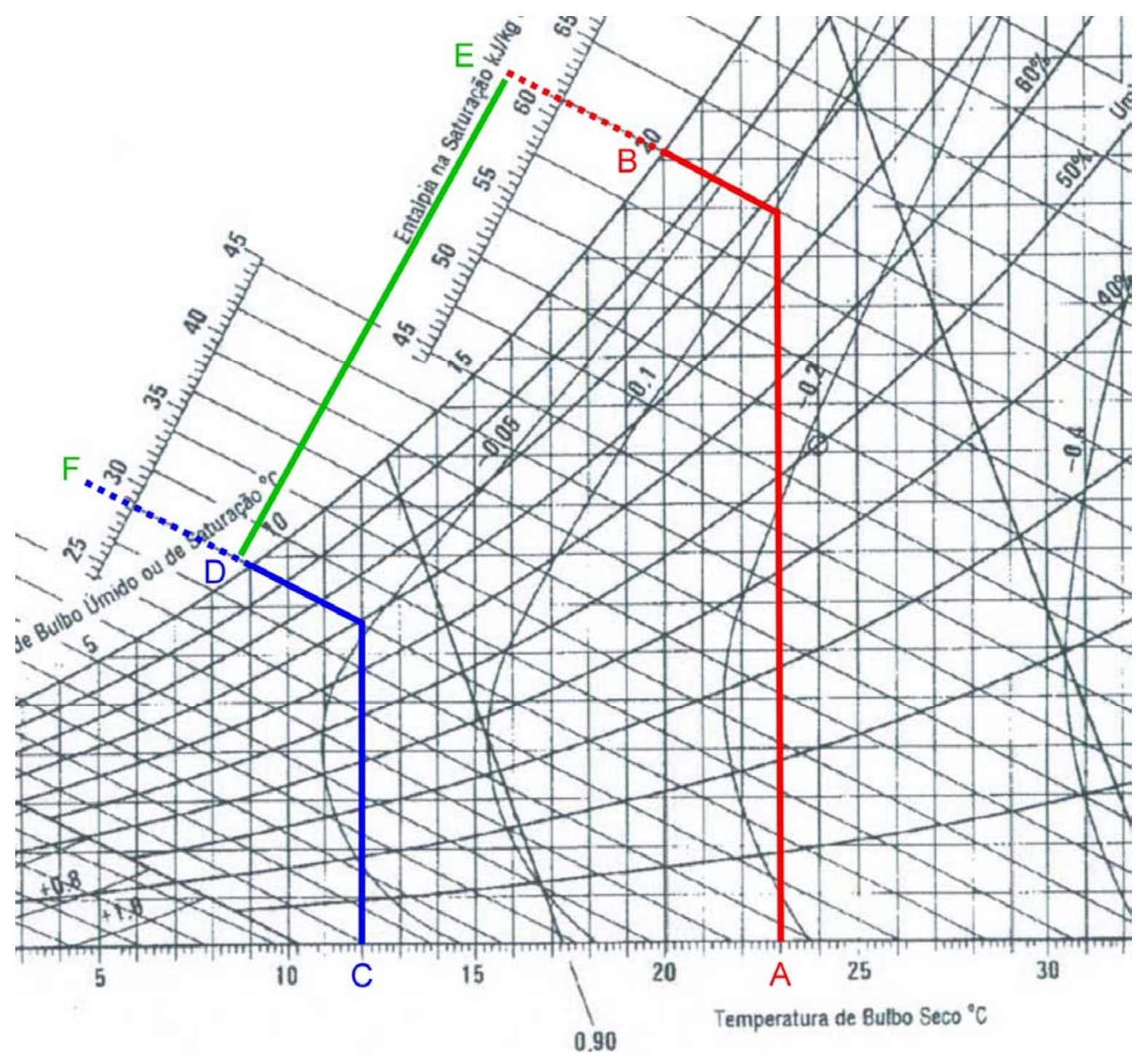

Figura 37 - Variação de entalpia utilizando condicionador tipo gincana com dissipação externa a ar. (A) Temperatura de bulbo seco inicial; (B) Temperatura de bulbo úmido inicial; $(C)$ Temperatura de bulbo seco final; (D) Temperatura de bulbo úmido final; (E) Entalpia inicial e (F) Entalpia final

$\mathrm{Na}$ carta psicrométrica, uma vez determinadas as temperaturas de bulbo seco (TBS), segue-se a linha vertical correspondente até que esta cruze com a linha em diagonal correspondente a temperatura de bulbo úmido (TBU). Esta intersecção determina a faixa de umidade relativa deste ponto. Partindo deste ponto e seguindo a linha diagonal na direção esquerda cruza-se a linha de entalpia. Dessa forma, subtraindo-se o valor da entalpia inicial do valor da entalpia final, tem-se a variação de entalpia do sistema. 
No presente ensaio, obteve-se:

- TBS Inicial $=23^{\circ} \mathrm{C}$

- $\mathrm{TBU}$ Inicial $=20^{\circ} \mathrm{C}$

- TBS Final $=12^{\circ} \mathrm{C}$

- TBU Final $=9^{\circ} \mathrm{C}$

Destes dados conclui-se:

- Entalpia Inicial = $61 \mathrm{~kJ} / \mathrm{kg}$ de Ar Seco;

- Entalpia Final = 28,75 kJ / kg de Ar Seco;

- Massa de ar total $=1,56 \mathrm{~kg}$ (convertido pela carta psicrométrica: Volume $\mathrm{m}^{3} / \mathrm{Kg}$ de $\mathrm{Ar}$ Seco; Volume/Segundo x 252 Segundos);

- Entalpia Total Inicial $=95,16 \mathrm{~kJ}$ (entalpia inicial multiplicado pela massa de ar total);

- Entalpia Total Final $=44,85 \mathrm{~kJ}$ (entalpia final multiplicado pela massa de ar total);

- Variação Total de Entalpia = 50,31 kJ.

A massa de ar total que passou pela gincana é obtida pela multiplicação da quantidade de ar pelo tempo do ensaio, multiplicado pelo fator de correção (aproximadamente 0,94 ) de acordo com a carta psicrométrica nas temperaturas iniciais. Na realidade esta é uma conversão de volume de ar para peso de ar (vazão mássica), o qual será utilizado no cálculo das entalpias totais envolvidas. Em sistemas de condicionamento de ar esta conversão é necessária em virtude de que os volumes são variáveis para uma mesma velocidade.

A energia fornecida ao sistema foi de $305,613 \mathrm{~kJ}$. Esse valor foi obtido multiplicando-se o valor da potência instantânea fornecida $(1,21275 \mathrm{~kW} ; 1 \mathrm{~kW}=1 \mathrm{~kJ}$ por segundo) pelo tempo de realização do trabalho (252 segundos; 21 séries multiplicado pelo tempo de execução de cada série que foi de 12 segundos).

A partir dos dados acima obteve-se o seguinte rendimento $(\eta)$, aplicandose os valores na equação (3):

$$
\begin{aligned}
& \eta=(50,31 \mathrm{~kJ} \times 100) / 305,613 \mathrm{~kJ} \\
& \eta \cong 0,1646 \text { ou } \\
& \eta \cong 16,46 \%
\end{aligned}
$$




\subsection{DESEMPENHO DO CONDICIONADOR TIPO GINCANA COM DISSIPAÇÃO EXTERNA ÁGUA}

A tabela 3 mostra a queda de temperatura ao longo do sistema de condicionamento com troca de calor a água logo após o início do ensaio, e a tabela 4 após 20 minutos de operação do sistema, com as temperaturas já estabilizadas.

Tabela 3 - Temperaturas $\left({ }^{\circ} \mathrm{C}\right)$ dos 12 termômetros no sistema de condicionamento tipo gincana com dissipação externa a água, durante as 21 séries de medições. Condições elétricas de operação: tensão de alimentação de 9 volts por semicondutor, consumo total de 5,3 amperes e potência de 524,7 watts por hora. Velocidade do ar condicionado de $1 \mathrm{~m} / \mathrm{s}$ e vazão de 5,82 litros por segundo. Vazão de água de arrefecimento de 1 litro por minuto - São Paulo - 2005

Termômetros

\begin{tabular}{ccccccccccccc}
\hline Séries $^{*}$ & 1 & 2 & 3 & 4 & 5 & 6 & 7 & 8 & 9 & 10 & 11 & 12 \\
\hline 1 & 23 & 23 & 23 & 23 & 23 & 23 & 23 & 23 & 23 & 23 & 23 & 23 \\
2 & 23 & 23 & 22 & 22 & 22 & 21 & 21 & 21 & 21 & 20 & 20 & 20 \\
3 & 23 & 22 & 21 & 20 & 20 & 20 & 20 & 20 & 19 & 19 & 19 & 19 \\
4 & 23 & 22 & 20 & 19 & 19 & 19 & 19 & 20 & 18 & 18 & 18 & 18 \\
5 & 23 & 21 & 19 & 19 & 19 & 18 & 17 & 18 & 17 & 16 & 16 & 16 \\
6 & 23 & 20 & 18 & 16 & 19 & 16 & 16 & 17 & 15 & 14 & 14 & 14 \\
7 & 23 & 20 & 17 & 15 & 18 & 15 & 15 & 17 & 14 & 12 & 12 & 12 \\
8 & 22 & 20 & 17 & 14 & 16 & 14 & 14 & 16 & 12 & 11 & 11 & 11 \\
9 & 22 & 20 & 16 & 13 & 15 & 13 & 13 & 15 & 11 & 10 & 10 & 10 \\
10 & 22 & 20 & 16 & 13 & 15 & 12 & 12 & 15 & 10 & 9 & 9 & 9 \\
11 & 22 & 19 & 15 & 12 & 15 & 11 & 11 & 13 & 9 & 8 & 8 & 8 \\
12 & 22 & 19 & 15 & 12 & 15 & 11 & 10 & 13 & 9 & 7 & 7 & 7 \\
13 & 22 & 19 & 15 & 12 & 15 & 10 & 10 & 13 & 8 & 6 & 6 & 6 \\
14 & 22 & 19 & 15 & 11 & 15 & 10 & 9 & 12 & 7 & 5 & 5 & 5 \\
15 & 22 & 19 & 15 & 11 & 15 & 10 & 9 & 12 & 7 & 5 & 5 & 5 \\
16 & 22 & 19 & 15 & 11 & 15 & 9 & 8 & 12 & 6 & 4 & 4 & 4 \\
17 & 22 & 19 & 15 & 11 & 15 & 9 & 8 & 12 & 5 & 3 & 3 & 3 \\
18 & 22 & 19 & 15 & 10 & 15 & 9 & 7 & 12 & 5 & 3 & 2 & 2 \\
19 & 22 & 19 & 15 & 10 & 15 & 8 & 7 & 11 & 3 & 2 & 1 & 1 \\
\hline
\end{tabular}

* Séries de tomadas de temperatura até a estabilização do sistema. Intervalos de tomadas de temperatura: 1 segundo entre cada termômetro e 12 segundos entre cada série. 
Tabela 4 - Temperaturas $\left({ }^{\circ} \mathrm{C}\right)$ dos 12 termômetros no sistema de condicionamento tipo gincana com dissipação externa a água após 20 minutos do início do ensaio. Condições elétricas de operação: tensão de alimentação de 9 volts por semicondutor, consumo total de 5,3 amperes e potência de 524,7 watts por hora. Velocidade do ar condicionado de $1 \mathrm{~m} / \mathrm{s}$ e vazão de 5,82 litros por segundo. Vazão de água de arrefecimento de 1 litro por minuto - São Paulo - 2005

\begin{tabular}{|c|c|c|c|c|c|c|c|c|c|c|c|c|}
\hline & \multicolumn{12}{|c|}{ Termômetros } \\
\hline & 1 & 2 & 3 & 4 & 5 & 6 & 7 & 8 & 9 & 10 & 11 & 12 \\
\hline Temperatura & 22 & 19 & 15 & 10 & 15 & 8 & 7 & 10 & 3 & 1 & 0 & 1 \\
\hline
\end{tabular}

As tabelas 3 e 4 também mostram a queda de temperatura do ar desde o início do ensaio até a estabilização do sistema. Da mesma forma que no sistema com dissipação externa a ar também ficou caracterizado 2 picos distintos de elevação de temperatura, registrados nos termômetros 5 e 8, demonstrando que a massa de ar absorve calor nas curvas independente da forma de dissipação de calor externo utilizado. Ao decorrer de 20 minutos, houve uma queda de temperatura de $21^{\circ} \mathrm{C}, 7^{\circ} \mathrm{C}$ a mais que no ensaio anterior.

A variação de entalpia, referente a este teste, pode ser visualizada no segmento da carta psicrométrica (Figura 38). 


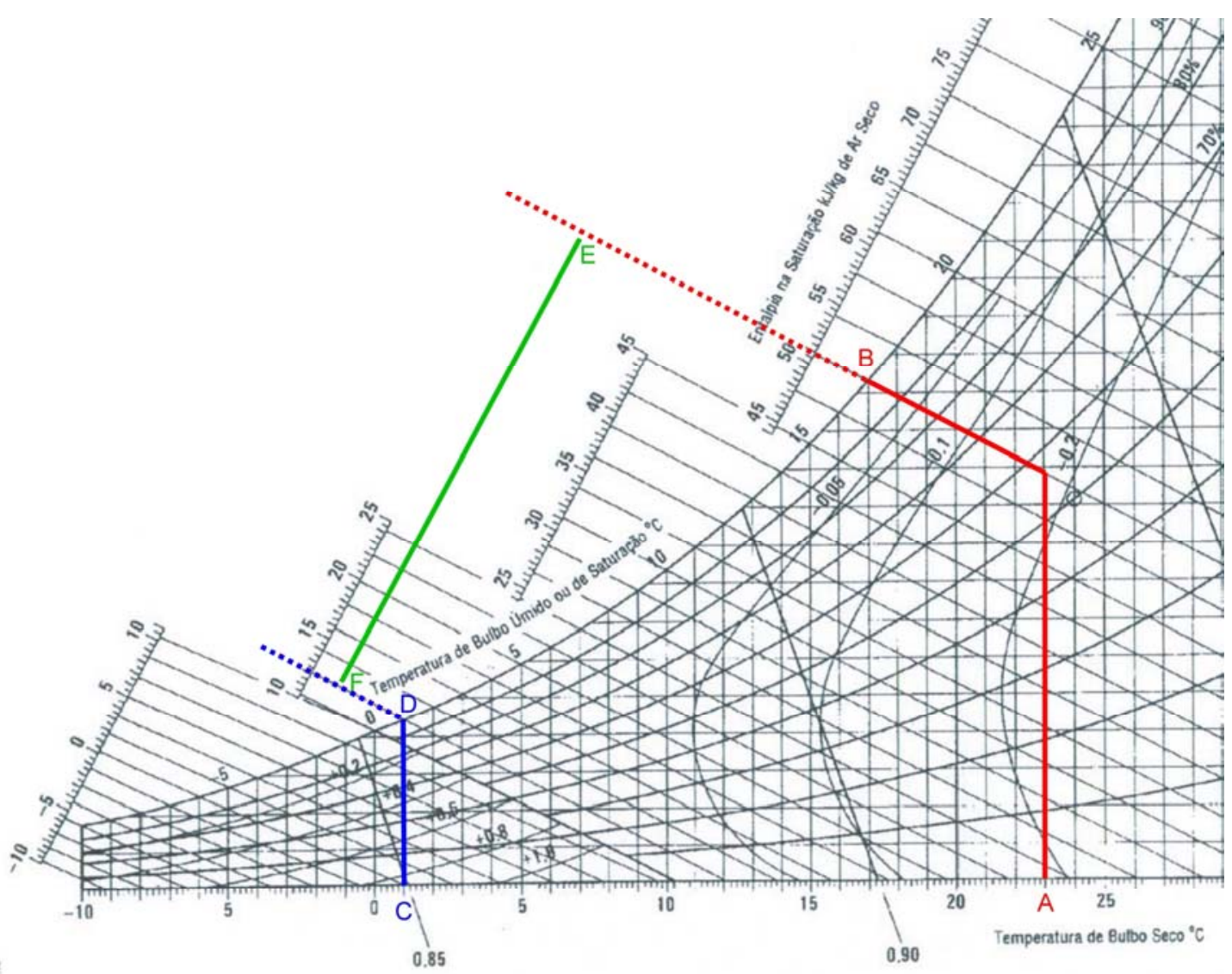

Abaixo de $0^{\circ} \mathrm{C}$ as Propriedades a Linhas de Correçăo de Entalpia, sắo para Geio

Figura 38 - Variação de entalpia utilizando condicionador tipo gincana com dissipação externa a água. (A) Temperatura de bulbo seco inicial; (B) Temperatura de bulbo úmido inicial; (C) Temperatura de bulbo seco final; (D) Temperatura de bulbo úmido final; $(E)$ Entalpia inicial e (F) Entalpia final

No presente ensaio, obteve-se:

- $\quad$ TBS Inicial $=23^{\circ} \mathrm{C}$

- $\quad$ TBU Inicial $=17^{\circ} \mathrm{C}$

- TBS Final $=1^{\circ} \mathrm{C}$

- $\quad$ TBU Final $=1^{\circ} \mathrm{C}$ 
Destes dados conclui-se:

- Entalpia Inicial = 50,75 kJ / kg de Ar Seco;

- $\quad$ Entalpia Final = 12,25 kJ / kg de Ar Seco;

- Massa de ar total $=1,43 \mathrm{~kg}$ (convertido pela carta psicrométrica: Volume $\mathrm{m}^{3} / \mathrm{kg}$ de Ar Seco; Volume/Segundo x 228 Segundos);

- Entalpia Total Inicial $=72,57 \mathrm{~kJ}$ (entalpia inicial multiplicado pela massa de ar total);

- Entalpia Total Final $=17,51 \mathrm{~kJ}$ (entalpia final multiplicado pela massa de ar total);

- Variação Total de Entalpia $=55,06$ kJ.

A massa de ar total que passou pela gincana é obtida pela multiplicação da quantidade de ar pelo tempo do ensaio, multiplicado pelo fator de correção (aproximadamente 0,93 ) de acordo com a carta psicrométrica nas temperaturas iniciais de bulbo seco e úmido.

A energia fornecida ao sistema foi de 119,631 kJ. Esse valor foi obtido multiplicando-se o valor da potência instantânea fornecida $(0,5247 \mathrm{~kW} ; 1 \mathrm{~kW}=1 \mathrm{~kJ}$ por segundo) pelo tempo de realização do trabalho (228 segundos; 19 séries multiplicado pelo tempo de execução de cada série que foi de 12 segundos).

A partir dos dados acima, obteve-se o seguinte rendimento $(\eta)$, aplicandose os valores na equação (3):

$$
\begin{aligned}
& \eta=(55,06 \mathrm{~kJ} \times 100) / 119,631 \mathrm{~kJ} \\
& \eta \cong 0,4602 \mathrm{ou} \\
& \eta \cong 46,02 \%
\end{aligned}
$$

Neste ensaio, em particular, notou-se TBS e TBU finais apresentando o mesmo valor $\left(1^{\circ} \mathrm{C}\right)$. Este fato é comum em sistemas de condicionamento de ar e representa uma condição psicrométrica denominada de "ponto de orvalho", no qual todo vapor de água presente no ar condensa-se. 


\subsection{SIMULAÇÃO MATEMÁTICA DE OPERAÇÃO DOS SISTEMAS}

Em uma situação hipotética, baseada nos dados obtidos até o momento, objetivando a comparação direta entre os ensaios, foi calculada a quantidade de microisoladores que podem ser beneficiados com o uso dos sistemas propostos. Esta é uma simulação matemática que pode ser perfeitamente aplicada a situações reais, respeitando as condições ambientais para cada caso.

Usando o recurso de diluição de fluidos, recurso este amplamente utilizado em sistemas convencionais para condicionamento de ar, pode-se chegar a uma temperatura final misturando duas massas de ar a temperaturas distintas. Para isso deve-se usar a seguinte fórmula:

$$
\frac{(\text { VolC } \times \text { TempC })+(\text { VolE } \times \text { TempE })}{\text { VolC }+ \text { VolE }}=\text { TempF }
$$

Aplicando-se valores hipotéticos na equação (4) para o primeiro ensaio, tem-se:

$$
\frac{(20952 \times 16)+(\text { VolE } \times 30)}{20952+\text { VolE }}=22
$$

Onde:

VolC $=20952$ litros;

$V o l E=$ Volume de ar externo, não condicionado;

Tетp $C=16^{\circ} \mathrm{C}$;

TempE $=30^{\circ} \mathrm{C}$;

TeтpF $=22^{\circ} \mathrm{C}$.

Obtem-se então VolE = 15701 litros de ar. 
Ou seja, a uma temperatura ambiente (ar externo) de $30^{\circ} \mathrm{C}$, a gincana de condicionamento, proposta no primeiro ensaio, seria capaz de fornecer uma massa de ar total de 36653 litros $(\mathrm{VolC}+\mathrm{VolE})$ a uma temperatura de $22^{\circ} \mathrm{C}$. Essa massa de ar deve ser dividida pelo volume do microisolador (20 litros, microisolador para ratos, volume aproximado) e posteriormente dividida pelo número de trocas de ar que se deseja no microisolador (neste caso assumiu-se 20 renovações completas de ar por hora). Dessa forma, este sistema é capaz de suprir aproximadamente 92 microisoladores, consumindo 1212,75 watts por hora.

Aplicando-se valores hipotéticos na equação (4) para o segundo ensaio, tem-se:

$$
\frac{(20952 \times 9)+(\text { VolE } \times 30)}{20952+\text { VolE }}=22
$$

Onde:

VolC $=20952$ litros;

VolE = Volume de ar externo, não condicionado;

Teтp $C=9^{\circ} \mathrm{C}$;

TempE $=30^{\circ} \mathrm{C}$;

TempF $=22^{\circ} \mathrm{C}$.

Obtem-se então VolE $=34047$ litros de ar.

Desta forma, para a mesma temperatura ambiente $\left(30^{\circ} \mathrm{C}\right)$, a gincana de condicionamento, no segundo ensaio, seria capaz de fornecer uma massa de ar total de 54999 litros $(\mathrm{VolC}+\mathrm{VolE})$ a uma temperatura de $22^{\circ} \mathrm{C}$ para aproximadamente 137 microisoladores para ratos, utilizando-se a metodologia descrita para o caso anterior, consumindo 524,7 watts por hora. 


\subsubsection{Comparação de Custo de Implantação por BTU Gerado}

O custo do equipamento de compressão do freon foi de $\mathrm{R} \$ 130.000,00$ (cento e trinta mil reais), aproximadamente, e sua capacidade é de 264.000 (duzentos e sessenta e quatro mil) BTU's/h. Os valores e a capacidade instalada foram obtidos da análise do processo.

Para a montagem do sistema termoelétrico foram gastos $R \$ 2.860,00$ (dois mil, oitocentos s sessenta reais) e sua capacidade é de 7.958 BTU's/h.

A comparação de custos por BTU's, revela:

1. Sistema de compressão de freon:

$\mathrm{R} \$ 130.000,00 / 264.000=\mathrm{R} \$ 0,49$ (aproximadamente).

2. Sistema termoelétrico:

RS 2.860,00/ $7958=\mathrm{R} \$$ 0,36 (aproximadamente).

\subsubsection{Comparação do Consumo Elétrico por BTU Gerado}

Abaixo, são relacionados os consumos elétricos para ambos os sistemas:

A) Sistema de compressão de freon: $25.580 \mathrm{~W} / \mathrm{h}$ (para 264.000 BTU/h)

B) Sistema termoelétrico com arrefecimento a água: $524,7 \mathrm{~W} / \mathrm{h}$ (para $7.958 \mathrm{BTU} / \mathrm{h})$

Tem-se, portanto:
A) $25.580 / 264.000=0,0968 \mathrm{~W} / \mathrm{BTU}$
B) $524,7 / 7958=0,0659$ W/BTU

Os dados acima mostram que o sistema termoelétrico arrefecido a água consome $\cong 32 \%$ menos energia que o ciclo de compressão do freon. Não foram efetuadas comparações com o sistema termoelétrico arrefecido a ar em virtude de seu baixo rendimento. 


\subsection{GANHO DE PESO E INGESTÃO DE RAÇÃO}

Para cada temperatura foram utilizados 15 animais. Visto que a CIT comporta somente 5 gaiolas, foram necessárias três repetições para cada condição experimental, sendo que para os testes estatísticos todas as repetições foram analisadas em conjunto. As tabelas 5 a 11 mostram a ingestão de ração e o ganho de peso, em gramas, para os grupos controle e os grupos experimentais mantidos respectivamente a $22 \pm 2^{\circ} \mathrm{C}$ (Grupo C I); $22 \pm 0,01^{\circ} \mathrm{C}$ (Grupo C II); $22 \pm 0,01^{\circ} \mathrm{C}$ (Grupo E I); $24 \pm 0,01^{\circ} \mathrm{C}$ (Grupo E II); $26 \pm 0,01^{\circ} \mathrm{C}$ (Grupo E III); $28 \pm 0,01^{\circ} \mathrm{C}$ (Grupo E IV) e $30 \pm 0,01^{\circ} \mathrm{C}$ (Grupo E V). 
Tabela 5 - Ingestão de ração (em gramas) e ganho de peso dos animais (em gramas). Grupo Controle (C I) - animais C1 a C15, mantidos a $22 \pm 2{ }^{\circ} \mathrm{C}$ em sistema de condicionamento de ar convencional - São Paulo - 2006

Grupo Controle C I a $22 \pm 2^{\circ} \mathrm{C}$

\begin{tabular}{|c|c|c|c|c|c|c|c|c|}
\hline Animal & Peso Inicial (g) & Ração 1 (g) & Sobra $1(\mathrm{~g})$ & Ração 2 (g) & Sobra 2 (g) & Peso Final (g) & Ingestão (g) & Ganho de peso $(\mathrm{g})$ \\
\hline $\mathrm{C} 1$ & 178,4 & 100,1 & 56,2 & 100,6 & 56,7 & 201 & 87,8 & 22,6 \\
\hline $\mathrm{C} 2$ & 172,3 & 101,7 & 52,8 & 99,2 & 53,3 & 194,3 & 94,8 & 22 \\
\hline C3 & 232,4 & 103,5 & 57,9 & 100,8 & 53,9 & 251 & 92,5 & 18,6 \\
\hline $\mathrm{C} 4$ & 193,8 & 102,3 & 63,2 & 98,8 & 54,3 & 212,7 & 83,6 & 18,9 \\
\hline C5 & 200 & 103,8 & 58,2 & 101,1 & 55,2 & 220,6 & 91,5 & 20,6 \\
\hline C6 & 201 & 100,3 & 54,5 & 105,1 & 60,5 & 221,1 & 90,4 & 20,1 \\
\hline $\mathrm{C} 7$ & 194,8 & 100,6 & 58,6 & 99,3 & 58 & 215,4 & 83,3 & 20,6 \\
\hline $\mathrm{C} 8$ & 223,8 & 100,1 & 53,8 & 99 & 52,6 & 246 & 92,7 & 22,2 \\
\hline $\mathrm{C9}$ & 172,1 & 100,4 & 60,8 & 99,4 & 55,4 & 194,3 & 83,6 & 22,2 \\
\hline C10 & 172,4 & 97,8 & 47,6 & 99,8 & 54,8 & 192,8 & 95,2 & 20,4 \\
\hline C11 & 181,4 & 101,2 & 54,2 & 100,4 & 53,2 & 203,2 & 94,2 & 21,8 \\
\hline C12 & 192,6 & 102,4 & 56,4 & 100,2 & 53,6 & 212,4 & 92,6 & 19,8 \\
\hline C13 & 200,8 & 100,6 & 54,2 & 102,4 & 54,2 & 220,4 & 94,6 & 19,6 \\
\hline C14 & 188,4 & 102 & 55,8 & 101,6 & 53,2 & 209,5 & 94,6 & 21,1 \\
\hline \multirow[t]{3}{*}{ C15 } & 204,2 & 100,8 & 50,4 & 98,8 & 54,3 & 225,2 & 94,9 & 21 \\
\hline & & & & & & Ingestão Média (g): & 91,09 & 20,77 \\
\hline & & & & & & Desvio Padrão: & 4,40 & 1,23 \\
\hline
\end{tabular}


Tabela 6 - Ingestão de ração (em gramas) e ganho de peso dos animais (em gramas). Grupo Controle (C II) - animais $\mathrm{C} 1$ a $\mathrm{C} 15$, mantidos a $22 \pm 0,1^{\circ} \mathrm{C}$ em sistema de condicionamento microambiental sem direcionamento de ar - São Paulo - 2006

Grupo Controle C II a $22 \pm 0,1^{\circ} \mathrm{C}$

\begin{tabular}{|c|c|c|c|c|c|c|c|c|}
\hline Animal & Peso Inicial (g) & Ração 1 (g) & Sobra $1(\mathrm{~g})$ & Ração 2 (g) & Sobra $2(\mathrm{~g})$ & Peso Final (g) & Ingestão (g) & Ganho de peso $(\mathrm{g})$ \\
\hline $\mathrm{C} 1$ & 232,4 & 102,8 & 60,9 & 104,3 & 55,1 & 252,8 & 91,1 & 20,4 \\
\hline $\mathrm{C} 2$ & 181,5 & 98,7 & 62,3 & 105,7 & 59 & 202,5 & 83,1 & 21 \\
\hline $\mathrm{C} 3$ & 205,6 & 102,8 & 65,2 & 103,4 & 56,9 & 227,2 & 84,1 & 21,6 \\
\hline $\mathrm{C} 4$ & 225,2 & 99,1 & 58,3 & 103,9 & 54 & 245,4 & 90,7 & 20,2 \\
\hline C5 & 212,6 & 99,9 & 60,1 & 105,5 & 61 & 235,2 & 84,3 & 22,6 \\
\hline $\mathrm{C} 6$ & 176 & 101,7 & 58,9 & 102,1 & 54,3 & 200,6 & 90,6 & 24,6 \\
\hline $\mathrm{C} 7$ & 220,2 & 99,3 & 60 & 100,5 & 45,4 & 244,2 & 94,4 & 24 \\
\hline $\mathrm{C} 8$ & 198,2 & 99,8 & 51,9 & 101,4 & 53,6 & 221,5 & 95,7 & 23,3 \\
\hline $\mathrm{C9}$ & 183,4 & 100,3 & 60,2 & 101 & 61 & 208,2 & 80,1 & 24,8 \\
\hline C10 & 214,4 & 99,7 & 54,3 & 99,1 & 48 & 238 & 96,5 & 23,6 \\
\hline C11 & 177,8 & 105,5 & 64,8 & 98,8 & 56,8 & 199,8 & 82,7 & 22 \\
\hline $\mathrm{C} 12$ & 191,4 & 102 & 60,4 & 98,2 & 54,3 & 211,8 & 85,5 & 20,4 \\
\hline C13 & 203,4 & 101,3 & 61,2 & 102,9 & 58,4 & 225,4 & 84,6 & 22 \\
\hline C14 & 200,3 & 100 & 63,4 & 99,4 & 51,4 & 224,2 & 84,6 & 23,9 \\
\hline \multirow[t]{3}{*}{ C15 } & 200,4 & 103,9 & 64,1 & 98,4 & 56,8 & 222,4 & 81,4 & 22 \\
\hline & & & & & & Ingestão Média (g): & 87,29 & 22,43 \\
\hline & & & & & & Desvio Padrão: & 5,38 & 1,55 \\
\hline
\end{tabular}


Tabela 7 - Ingestão de ração (em gramas) e ganho de peso dos animais (em gramas). Grupo Experimental $(E \mathrm{I})$ - animais $\mathrm{E} 1$ a $\mathrm{E} 15$, mantidos a $22 \pm 0,1^{\circ} \mathrm{C}$ em sistema de condicionamento microambiental - São Paulo - 2006

Grupo Experimental E I a $22 \pm 0,1^{\circ} \mathrm{C}$

\begin{tabular}{|c|c|c|c|c|c|c|c|c|}
\hline Animal & Peso Inicial $(\mathrm{g})$ & Ração 1 (g) & Sobra $1(\mathrm{~g})$ & Ração 2 (g) & Sobra $2(\mathrm{~g})$ & Peso Final (g) & Ingestão (g) & Ganho de peso (g) \\
\hline E1 & 185 & 101,6 & 54,9 & 101,3 & 51,6 & 204,6 & 96,4 & 19,6 \\
\hline E2 & 173,2 & 100,2 & 57,5 & 99,3 & 56,6 & 187,2 & 85,4 & 14 \\
\hline E3 & 174,2 & 100,7 & 60 & 102,8 & 58,1 & 190,2 & 85,4 & 16 \\
\hline E4 & 182,1 & 99,8 & 57,9 & 104,1 & 62 & 197,2 & 84 & 15,1 \\
\hline E5 & 185,2 & 102,1 & 55,5 & 100 & 49,6 & 202 & 97 & 16,8 \\
\hline E6 & 210,4 & 103,8 & 55,7 & 99,1 & 51 & 224 & 96,2 & 13,6 \\
\hline E7 & 201,2 & 100,7 & 57,2 & 99,6 & 53,2 & 215 & 89,9 & 13,8 \\
\hline E8 & 210,2 & 104,7 & 60,2 & 100,8 & 50,5 & 227 & 94,8 & 16,8 \\
\hline E9 & 192,3 & 100,4 & 59 & 101,7 & 58,7 & 207 & 84,4 & 14,7 \\
\hline E10 & 202 & 102,7 & 52 & 100,5 & 50 & 215 & 101,2 & 13 \\
\hline E11 & 174,8 & 100,7 & 60,6 & 102 & 55,7 & 192,4 & 86,4 & 17,6 \\
\hline E12 & 184,8 & 96,7 & 54,2 & 102 & 59,4 & 199,4 & 85,1 & 14,6 \\
\hline E13 & 184,2 & 98,7 & 58,2 & 101,6 & 58,1 & 201,2 & 84 & 17 \\
\hline E14 & 181,2 & 94,4 & 40 & 102,8 & 55 & 193,4 & 102,2 & 12,2 \\
\hline \multirow[t]{3}{*}{ E15 } & 183,2 & 93,7 & 52,4 & 103,1 & 61,3 & 197,4 & 83,1 & 14,2 \\
\hline & & & & & & Ingestão Média (g): & 90,37 & 15,27 \\
\hline & & & & & & Desvio Padrão: & 6,83 & 1,99 \\
\hline
\end{tabular}


Tabela 8 - Ingestão de ração (em gramas) e ganho de peso dos animais (em gramas). Grupo Experimental (E II) - animais $E 1$ a $E 15$, mantidos a $24 \pm 0,1^{\circ} \mathrm{C}$ em sistema de condicionamento microambiental - São Paulo - 2006

Grupo Experimental E II a $24 \pm 0,1^{\circ} \mathrm{C}$

\begin{tabular}{|c|c|c|c|c|c|c|c|c|}
\hline Animal & Peso Inicial $(\mathrm{g})$ & Ração 1 (g) & Sobra $1(\mathrm{~g})$ & Ração 2 (g) & Sobra $2(\mathrm{~g})$ & Peso Final (g) & Ingestão (g) & Ganho de peso (g) \\
\hline E1 & 196,4 & 104,1 & 61,5 & 102,8 & 55,7 & 213,8 & 89,7 & 17,4 \\
\hline E2 & 194,2 & 103,1 & 55,7 & 101,3 & 50,3 & 211,4 & 98,4 & 17,2 \\
\hline E3 & 190 & 102 & 61,8 & 104,1 & 57 & 205,6 & 87,3 & 15,6 \\
\hline E4 & 203,8 & 102,3 & 58,3 & 103,9 & 52,6 & 221,4 & 95,3 & 17,6 \\
\hline E5 & 196,2 & 100,5 & 55,5 & 102,9 & 58,9 & 210,7 & 89 & 14,5 \\
\hline E6 & 194,4 & 102,1 & 58,3 & 99,8 & 53,3 & 209,8 & 90,3 & 15,4 \\
\hline E7 & 208,6 & 100,4 & 57,1 & 101,9 & 55,9 & 225,8 & 89,3 & 17,2 \\
\hline E8 & 208,8 & 100,2 & 56,3 & 102,4 & 56,3 & 228,4 & 90 & 19,6 \\
\hline E9 & 223,7 & 100,8 & 47,6 & 100,2 & 53,6 & 243,2 & 99,8 & 19,5 \\
\hline E10 & 189,4 & 100,1 & 54,5 & 102,4 & 59,2 & 207,4 & 88,8 & 18 \\
\hline E11 & 200,2 & 101,6 & 56,7 & 103,1 & 54,3 & 218,4 & 93,7 & 18,2 \\
\hline E12 & 182,6 & 103,2 & 56,3 & 102,3 & 55,6 & 201,2 & 93,6 & 18,6 \\
\hline E13 & 190,2 & 99,6 & 56,5 & 101,8 & 55 & 207 & 89,9 & 16,8 \\
\hline E14 & 199 & 100,8 & 48,5 & 100,1 & 51,2 & 218,4 & 101,2 & 19,4 \\
\hline \multirow[t]{3}{*}{ E15 } & 174,2 & 101,6 & 59,9 & 99,9 & 59,3 & 190,2 & 82,3 & 16 \\
\hline & & & & & & Ingestão Média (g): & 91,91 & 17,40 \\
\hline & & & & & & Desvio Padrão: & 5,08 & 1,55 \\
\hline
\end{tabular}


Tabela 9 - Ingestão de ração (em gramas) e ganho de peso dos animais (em gramas). Grupo Experimental (E III) - animais $\mathrm{E} 1$ a $\mathrm{E} 15$, mantidos a $26 \pm 0,1^{\circ} \mathrm{C}$ em sistema de condicionamento microambiental - São Paulo - 2006

Grupo Experimental E III a $26 \pm 0,1^{\circ} \mathrm{C}$

\begin{tabular}{|c|c|c|c|c|c|c|c|c|}
\hline Animal & Peso Inicial (g) & Ração 1 (g) & Sobra $1(\mathrm{~g})$ & Ração 2 (g) & Sobra $2(\mathrm{~g})$ & Peso Final $(\mathrm{g})$ & Ingestão (g) & Ganho de peso $(\mathrm{g})$ \\
\hline E1 & 185,8 & 106,4 & 62 & 100,3 & 52,5 & 208,2 & 92,2 & 22,4 \\
\hline E2 & 185,2 & 101,1 & 60,5 & 107,1 & 63,3 & 207,2 & 84,4 & 22 \\
\hline E3 & 192,4 & 100,1 & 60,9 & 104,4 & 64,9 & 214 & 78,7 & 21,6 \\
\hline E4 & 173,2 & 100,6 & 60 & 103,2 & 61,8 & 194 & 82 & 20,8 \\
\hline E5 & 178,4 & 101 & 55,3 & 101,8 & 54,9 & 198 & 92,6 & 19,6 \\
\hline E6 & 158,2 & 99,9 & 58,6 & 98 & 58,2 & 177,5 & 81,1 & 19,3 \\
\hline E7 & 166,8 & 102,1 & 54,9 & 101,9 & 60,9 & 183,4 & 88,2 & 16,6 \\
\hline E8 & 166,4 & 98,6 & 60,3 & 101,1 & 64,6 & 182,6 & 74,8 & 16,2 \\
\hline E9 & 190,4 & 103,4 & 64,4 & 99,7 & 57,3 & 207,4 & 81,4 & 17 \\
\hline E10 & 183,2 & 97,7 & 61,5 & 97,5 & 59 & 203,2 & 74,7 & 20 \\
\hline E11 & 190,2 & 103,4 & 59,4 & 98 & 56 & 208,4 & 86 & 18,2 \\
\hline E12 & 196,8 & 100,4 & 57,4 & 103,8 & 57,8 & 216,8 & 89 & 20 \\
\hline E13 & 179,6 & 102,5 & 58 & 100,5 & 56,4 & 197,4 & 88,6 & 17,8 \\
\hline E14 & 202 & 100,6 & 54,6 & 101,1 & 57,2 & 219,8 & 89,9 & 17,8 \\
\hline \multirow[t]{3}{*}{ E15 } & 198,2 & 100,8 & 57,4 & 100,8 & 56,2 & 216,4 & 88 & 18,2 \\
\hline & & & & & & Ingestão Média (g & 84,77 & 19,17 \\
\hline & & & & & & Desvio Padrã & 5,79 & 1,97 \\
\hline
\end{tabular}


Tabela 10 - Ingestão de ração (em gramas) e ganho de peso dos animais (em gramas). Grupo Experimental (E IV) - animais $\mathrm{E} 1$ a $\mathrm{E} 15$, mantidos a $28 \pm 0,1^{\circ} \mathrm{C}$ em sistema de condicionamento microambiental - São Paulo - 2006

Grupo Experimental E IV a $28 \pm 0,1^{\circ} \mathrm{C}$

\begin{tabular}{|c|c|c|c|c|c|c|c|c|}
\hline Animal & Peso Inicial (g) & Ração 1 (g) & Sobra $1(\mathrm{~g})$ & Ração 2 (g) & Sobra $2(\mathrm{~g})$ & Peso Final (g) & Ingestão (g) & Ganho de peso (g) \\
\hline E1 & 206,4 & 104,6 & 56,7 & 99,7 & 53,8 & 228,1 & 93,8 & 21,7 \\
\hline E2 & 236,4 & 105,1 & 61,4 & 106,5 & 65,6 & 257,2 & 84,6 & 20,8 \\
\hline E3 & 214,8 & 107 & 58 & 102,5 & 58 & 236,2 & 93,5 & 21,4 \\
\hline E4 & 215,3 & 107,4 & 59,2 & 104,2 & 57 & 236,8 & 95,4 & 21,5 \\
\hline E5 & 213,1 & 104,4 & 60,6 & 104,3 & 62,6 & 235,1 & 85,5 & 22 \\
\hline E6 & 183,5 & 100,8 & 52,2 & 101,1 & 56,2 & 201 & 93,5 & 17,5 \\
\hline E7 & 179 & 100,8 & 59,2 & 100,7 & 58,7 & 198,2 & 83,6 & 19,2 \\
\hline E8 & 180 & 101,3 & 65 & 101 & 60 & 198,8 & 77,3 & 18,8 \\
\hline E9 & 157,8 & 101,8 & 63,4 & 102,5 & 62,5 & 175 & 78,4 & 17,2 \\
\hline E10 & 173,2 & 105,3 & 61 & 99,5 & 58,6 & 191 & 85,2 & 17,8 \\
\hline E11 & 198,4 & 101,1 & 54,6 & 102,8 & 59,3 & 218,8 & 90 & 20,4 \\
\hline E12 & 202,4 & 101,2 & 57,8 & 103,7 & 60,1 & 221,8 & 87 & 19,4 \\
\hline E13 & 201,2 & 101,1 & 56,9 & 102 & 61,2 & 221 & 85 & 19,8 \\
\hline E14 & 192,8 & 102,4 & 60,5 & 99,8 & 60,3 & 211,8 & 81,4 & 19 \\
\hline \multirow[t]{3}{*}{ E15 } & 184,8 & 101,6 & 50,5 & 100,6 & 63,5 & 204,8 & 88,2 & 20 \\
\hline & & & & & & Ingestão Média (g): & 86,83 & 19,77 \\
\hline & & & & & & Desvio Padrão: & 5,59 & 1,55 \\
\hline
\end{tabular}


Tabela 11 - Ingestão de ração (em gramas) e ganho de peso dos animais (em gramas). Grupo Experimental $(E \mathrm{~V})$ - animais $\mathrm{E} 1$ a $\mathrm{E} 15$, mantidos a $30 \pm 0,1^{\circ} \mathrm{C}$ em sistema de condicionamento microambiental - São Paulo - 2006

Grupo Experimental E V a $30 \pm 0,1^{\circ} \mathrm{C}$

\begin{tabular}{|c|c|c|c|c|c|c|c|c|}
\hline Animal & Peso Inicial (g) & Ração 1 (g) & Sobra $1(\mathrm{~g})$ & Ração 2 (g) & Sobra $2(\mathrm{~g})$ & Peso Final $(\mathrm{g})$ & Ingestão (g) & Ganho de peso $(\mathrm{g})$ \\
\hline E1 & 230 & 100,7 & 56,7 & 100 & 56,6 & 251,2 & 87,4 & 21,2 \\
\hline E2 & 219,3 & 101,2 & 57,8 & 101,8 & 61,1 & 242,8 & 84,1 & 23,5 \\
\hline E3 & 218,6 & 104,9 & 59,3 & 100,1 & 61,6 & 238,4 & 84,1 & 19,8 \\
\hline E4 & 192,4 & 100 & 58,4 & 103,1 & 59,6 & 212,1 & 85,1 & 19,7 \\
\hline E5 & 203 & 101 & 63,3 & 102 & 61,2 & 225,2 & 78,5 & 22,2 \\
\hline E6 & 205,4 & 100,4 & 65,3 & 99,5 & 61,3 & 229,8 & 73,3 & 24,4 \\
\hline E7 & 227,2 & 98,7 & 46,7 & 101,9 & 65,5 & 251,6 & 88,4 & 24,4 \\
\hline E8 & 225,2 & 98 & 61,7 & 101,1 & 64 & 247,4 & 73,4 & 22,2 \\
\hline E9 & 230,8 & 99,5 & 55,9 & 99,8 & 63,5 & 251,4 & 79,9 & 20,6 \\
\hline E10 & 210,1 & 99,6 & 57,9 & 100,3 & 61,2 & 231,2 & 80,8 & 21,1 \\
\hline E11 & 184,2 & 99,4 & 68,3 & 99,4 & 50,8 & 207,8 & 79,7 & 23,6 \\
\hline E12 & 204,4 & 99,3 & 56 & 99,3 & 57,9 & 227,4 & 84,7 & 23 \\
\hline E13 & 222 & 99,3 & 55,7 & 99,3 & 57 & 244,4 & 85,9 & 22,4 \\
\hline E14 & 220 & 101,8 & 52,3 & 101,8 & 60,4 & 243,2 & 90,9 & 23,2 \\
\hline \multirow[t]{3}{*}{ E15 } & 208 & 100,2 & 57 & 100,2 & 55,4 & 229,6 & 88 & 21,6 \\
\hline & & & & & & Ingestão Média ( & 82,95 & 22,19 \\
\hline & & & & & & Desvio Padrã & 5,25 & 1,52 \\
\hline
\end{tabular}


As tabelas 12 e 13 mostram, respectivamente, a ingestão total de ração e ganho de peso por animal durante os 5 dias de experimento, bem como as médias $(n=15)$, desvios padrão e as respectivas análises estatísticas. A figura 39 ilustra a curva de ingestão de ração por grupo e a figura 40 ilustra a curva de ganho de peso por grupo, mantidos em cinco condições termohigrométricas experimentais propostas. 
Tabela 12 - Ingestão de ração total (em gramas) por animal / grupo ( $n=15)$, durante 5 dias - São Paulo - 2006

\begin{tabular}{|c|c|c|c|c|c|c|c|}
\hline Animal & $\mathrm{Cl}$ & C II & E I & EII & E III & EIV & FV \\
\hline 1 & 87,8 & 91,1 & 96,4 & 89,7 & 92,2 & 93,8 & 87,4 \\
\hline 2 & 94,8 & 83,1 & 85,4 & 98,4 & 84,4 & 84,6 & 84,1 \\
\hline 3 & 92,5 & 84,1 & 85,4 & 87,3 & 78,7 & 93,5 & 84,1 \\
\hline 4 & 83,6 & 90,7 & 84 & 95,3 & 82 & 95,4 & 85,1 \\
\hline 5 & 91,5 & 84,3 & 97 & 89 & 92,6 & 85,5 & 78,5 \\
\hline 6 & 90,4 & 90,6 & 96,2 & 90,3 & 81,1 & 93,5 & 73,3 \\
\hline 7 & 83,3 & 94,4 & 89,9 & 89,3 & 88,2 & 83,6 & 88,4 \\
\hline 8 & 92,7 & 95,7 & 94,8 & 90 & 74,8 & 77,3 & 73,4 \\
\hline 9 & 83,6 & 80,1 & 84,4 & 99,8 & 81,4 & 78,4 & 79,9 \\
\hline 10 & 95,2 & 96,5 & 101,2 & 88,8 & 74,7 & 85,2 & 80,8 \\
\hline 11 & 94,2 & 82,7 & 86,4 & 93,7 & 86 & 90 & 79,7 \\
\hline 12 & 92,6 & 85,5 & 85,1 & 93,6 & 89 & 87 & 84,7 \\
\hline 13 & 94,6 & 84,6 & 84 & 89,9 & 88,6 & 85 & 85,9 \\
\hline 14 & 94,6 & 84,6 & 102,2 & 101,2 & 89,9 & 81,4 & 90,9 \\
\hline 15 & 94,9 & 81,4 & 83,1 & 82,3 & 88 & 88,2 & 88 \\
\hline $\begin{array}{l}\text { Ingestão Média }(\mathrm{g}) \\
\text { por grupo }(\mathrm{n}=15) \text { : }\end{array}$ & $91,09^{(1)}$ & 87,29 & $90,37^{(2)}$ & $91,91^{(3)}$ & 84,77 & 86,83 & 82,95 \\
\hline Desvio Padrão: & 4,40 & 5,38 & 6,83 & 5,08 & 5,79 & 5,59 & 5,25 \\
\hline
\end{tabular}

(1) - Diferença estatística significativa com o E III ( $p<0,05)$; Diferença estatística significativa com o E V ( $p<0,01)$.

(2) - Diferença estatística significativa com o E V $(p<0,01)$.

(3) - Diferença estatística significativa com o E III ( $p<0,05)$; Diferença estatística significativa com o E V ( $p<0,001)$. 


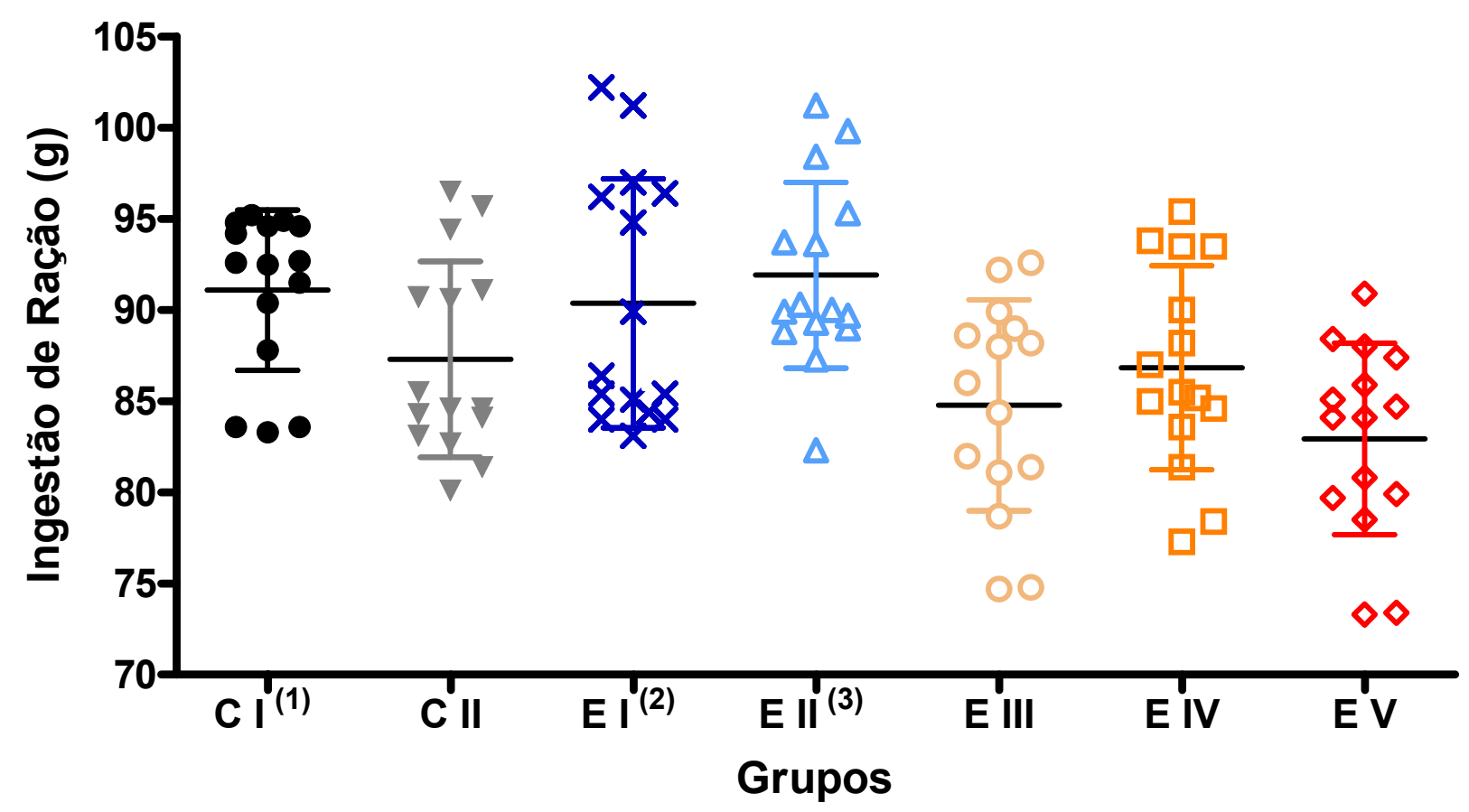

(1) - Diferença estatística significativa com o E III ( $p<0,05)$; Diferença estatística significativa com o $E \mathrm{~V}(p<0,01)$.

(2) - Diferença estatística significativa com o E V $(p<0,01)$

(3) - Diferença estatística significativa com o E III ( $p<0,05)$; Diferença estatística significativa com o E V ( $p<0,001)$. 
Tabela 13 - Ganho de peso total (em gramas), por animal / grupo ( $n=15)$, durante 5 dias - São Paulo - 2006

\begin{tabular}{|c|c|c|c|c|c|c|c|}
\hline \multicolumn{8}{|c|}{ Ganho de Peso por Animal / Grupo } \\
\hline Animal & $\mathrm{Cl}$ & C II & EI & E II & E III & E IV & $\mathrm{EV}$ \\
\hline 1 & 22,6 & 20,4 & 19,6 & 17,4 & 22,4 & 21,7 & 21,2 \\
\hline 2 & 22 & 21 & 14 & 17,2 & 22 & 20,8 & 23,5 \\
\hline 3 & 18,6 & 21,6 & 16 & 15,6 & 21,6 & 21,4 & 19,8 \\
\hline 4 & 18,9 & 20,2 & 15,1 & 17,6 & 20,8 & 21,5 & 19,7 \\
\hline 5 & 20,6 & 22,6 & 16,8 & 14,5 & 19,6 & 22 & 22,2 \\
\hline 6 & 20,1 & 24,6 & 13,6 & 15,4 & 19,3 & 17,5 & 24,4 \\
\hline 7 & 20,6 & 24 & 13,8 & 17,2 & 16,6 & 19,2 & 24,4 \\
\hline 8 & 22,2 & 23,3 & 16,8 & 19,6 & 16,2 & 18,8 & 22,2 \\
\hline 9 & 22,2 & 24,8 & 14,7 & 19,5 & 17 & 17,2 & 20,6 \\
\hline 10 & 20,4 & 23,6 & 13 & 18 & 20 & 17,8 & 21,1 \\
\hline 11 & 21,8 & 22 & 17,6 & 18,2 & 18,2 & 20,4 & 23,6 \\
\hline 12 & 19,8 & 20,4 & 14,6 & 18,6 & 20 & 19,4 & 23 \\
\hline 13 & 19,6 & 22 & 17 & 16,8 & 17,8 & 19,8 & 22,4 \\
\hline 14 & 21,1 & 23,9 & 12,2 & 19,4 & 17,8 & 19 & 23,2 \\
\hline 15 & 21 & 22 & 14,2 & 16 & 18,2 & 20 & 21,6 \\
\hline $\begin{array}{l}\text { Peso Médio }(\mathrm{g}) \\
\text { por grupo }(\mathrm{n}=15) \text { : }\end{array}$ & $20,77^{(1)}$ & $22,43^{(2)}$ & $15,27^{(3)}$ & $17,40^{(4)}$ & $19,17^{(5)}$ & 19,77 & 22,19 \\
\hline Desvio Padrão: & 1,23 & 1,55 & 1,99 & 1,55 & 1,97 & 1,55 & 1,52 \\
\hline
\end{tabular}

(1) - Diferença estatística significativa com o E I $(p<0,001)$; Diferença estatística significativa com o E II $(p<0,001)$.

(2) - Diferença estatística significativa com o E I $(p<0,001)$; Diferença estatística significativa com o $E$ II $(p<0,001)$; Diferença estatística significativa com o E III $(p<0,01)$; Diferença estatística significativa com o E IV $(p<0,001)$.

(3) - Diferença estatística significativa com o E II $(p<0,05)$; Diferença estatística significativa com o E III ( $p<0,001)$

Diferença estatística significativa com o E IV ( $p<0,001)$; Diferença estatística significativa com o E V $(p<0,001)$

(4) - Diferença estatística significativa com o E IV ( $p<0,01)$; Diferença estatística significativa com o $E \vee(p<0,001)$.

(5) - Diferença estatística significativa com o $E \vee(p<0,001)$ 


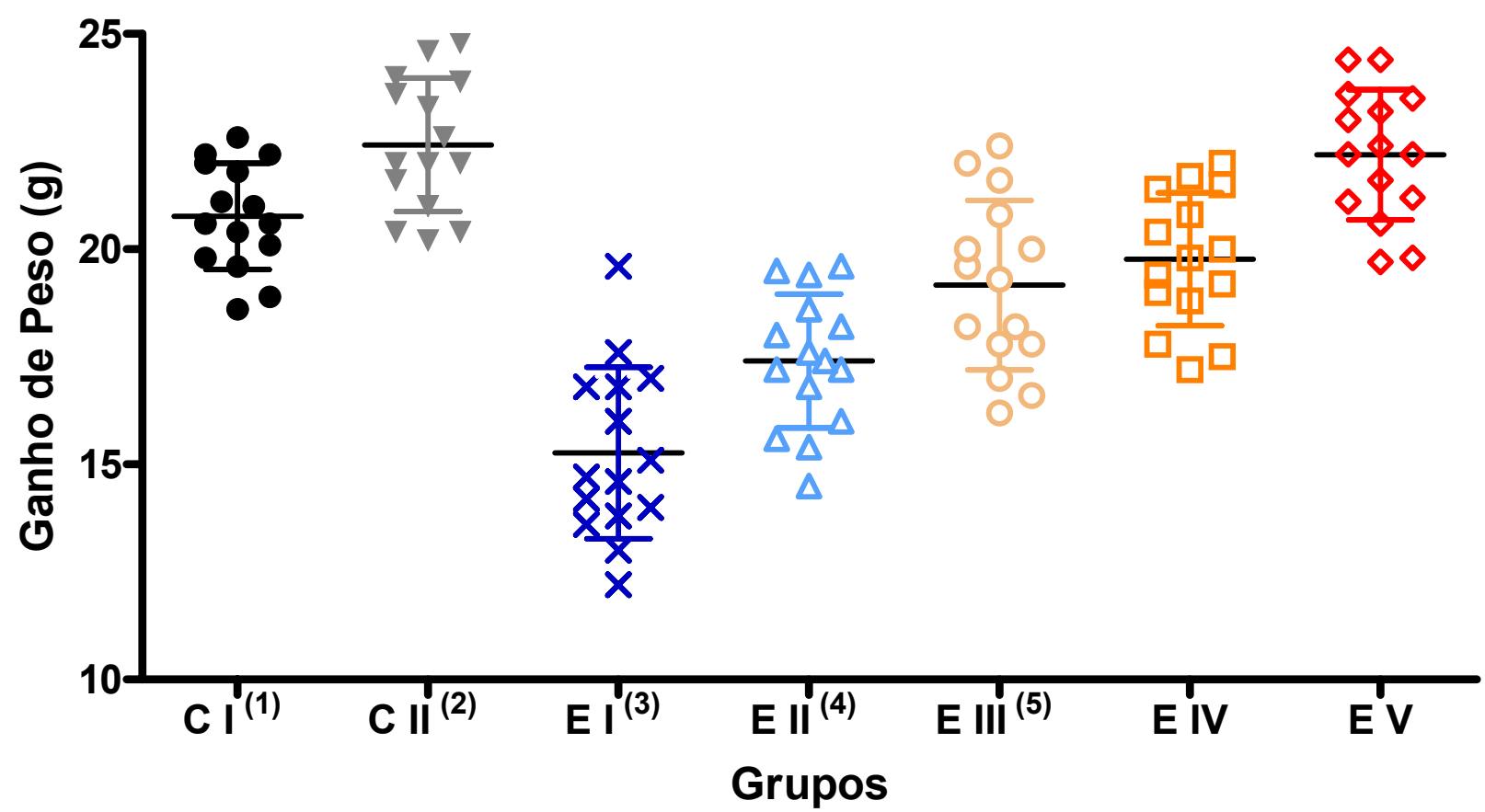

(1) - Diferença estatística significativa com o E I ( $p<0,001)$; Diferença estatística significativa com o E II $(p<0,001)$.

(2) - Diferença estatística significativa com o E I ( $p<0,001)$; Diferença estatística significativa com o E II ( $p<0,001)$; Diferença estatística significativa com o E III ( $p<0,01)$; Diferença estatística significativa com o E IV $(p<0,001)$.

(3) - Diferença estatística significativa com o E II $(p<0,05)$; Diferença estatística significativa com o E III ( $p<0,001)$; Diferença estatística significativa com o E IV ( $p<0,001)$; Diferença estatística significativa com o E V $(p<0,001)$.

(4) - Diferença estatística significativa com o E IV ( $p<0,01)$; Diferença estatística significativa com o $E \vee(p<0,001)$.

(5) - Diferença estatística significativa com o E V $(p<0,001)$

Figura 40 - Curva de ganho de peso, em gramas, por grupo $(n=15)$ 


\subsection{CONCENTRAÇÃO DE AMÔNIA}

A tabela 14 mostra a concentração de amônia, junto ao piso das gaiolas, durante os 5 dias de experimento para cada grupo estudado. As medidas foram feitas ao $3^{\circ}$ e $5^{\circ}$ dias, antes da limpeza das gaiolas metabólicas.

Tabela 14 - Concentração de gás de amônia (em ppm), por dia / grupo, no decorrer de 5 dias, n=5 - São Paulo - 2006

\begin{tabular}{cccccccc}
\hline \multicolumn{7}{l}{ Gás de Amônia (em ppm) / Grupos } \\
\hline C I & C II & E I & E II & E III & E IV & E V \\
\hline $3^{\circ}$ Dia & 2 & 1 & 1 & 1 & 0 & 0 & 0 \\
$5^{\circ}$ Dia & 4 & 3 & 1 & 1 & 0 & 1 & 0 \\
\hline
\end{tabular}


Embora a tecnologia termoelétrica (TT) seja conhecida desde o século XIX, inúmeros fatores retardaram a aplicação industrial do fenômeno, tais como a falta de elementos com maior potencial termoelétrico. Posteriormente, com a descoberta de novos materiais, sintetização de novas ligas e avanços nos processos de purificação, materiais de alto potencial termoelétrico foram disponibilizados. Com o advento da exploração aeroespacial esta tecnologia foi aperfeiçoada tendo em vista a necessidade de sua utilização, por exemplo, em satélites. A partir de então, com a utilização de ligas de grande potencial termoelétrico, tal como o telureto de bismuto e a fabricação de células termoelétricas em escala industrial, houve uma grande popularização do fenômeno. Inicialmente, em artigos de consumo populares, tais como mini-adegas e posteriormente em equipamentos mais sofisticados de laboratório, tais como termocicladores empregados em pesquisas de DNA.

Os avanços conseguidos na distribuição do ar, com o advento da ventilação microambiental (VMA) permitiram aventar a hipótese da utilização da TT para animais de laboratório. De acordo com Merusse ${ }^{1}$ (2005), "o emprego da VMA admite uma redução de aproximadamente $70 \%$ da massa de ar a ser renovada, quando comparada com a ventilação clássica que preconiza a troca completa da massa de ar da sala" (informação verbal). Além disso, nos sistemas de VMA, quando bem projetados, é característico o fenômeno da convecção forçada, 3 a 4 vezes mais eficiente, no caso de animais de laboratório, do que a convecção livre (HOLMAN, 1983).

Dessa forma, com a experiência acumulada no LAMBDA, tornou-se possível avançar, não mais na distribuição do ar, mas no tratamento termohigrométrico, através da TT.

Os módulos termoelétricos transferem energia térmica de uma de suas superfícies para outra. Dessa forma, os primeiros ensaios foram direcionados para a dissipação desta energia de uma das faces dos módulos. Embora já fosse conhecido que a transferência de calor por condução guarda uma relação direta de eficiência com a densidade do meio (HOLMAN, 1983), optou-se pela realização de um ensaio visando a rejeição do calor para o ar, bem como a capacidade frigorígena dos módulos nessa condição, a qual permite uma construção muito simples para os trocadores de calor. Os resultados apontaram (Tabelas 1 e 2) para um aumento da

\footnotetext{
${ }^{1}$ Informação fornecida por Merusse, em 2005.
} 
temperatura nas regiões circunvizinhas às áreas de resfriamento dos módulos e $\Delta t$ de $14^{\circ} \mathrm{C}$, após a estabilização do sistema, para uma vazão de 5,82 l/s, gerando uma variação de entalpia de $50,31 \mathrm{~kJ}$ na massa de ar refrigerado e rendimento $\eta \cong$ $16,46 \%$.

De posse destes resultados, considerou-se válida a verificação do rendimento a partir do arrefecimento dos módulos com a utilização de água (Tabelas 3 e 4). Neste ensaio, obteve-se $\Delta \mathrm{t}$ de $21^{\circ} \mathrm{C}$, variação de entalpia $55,06 \mathrm{~kJ}$ e $\eta \cong$ 46,02\%, manteve-se a vazão de ar e $1 \mathrm{l} / \mathrm{m}$ de vazão de água de arrefecimento.

Estes dois ensaios apontam para a necessidade de arrefecimento a água de eventuais módulos comerciais de TT para biotérios. Nota-se que no sistema arrefecido a ar, o consumo elétrico foi de $\cong 1212 \mathrm{~W} / \mathrm{h}$ e no arrefecido a água, de $\cong$ $524 \mathrm{~W} / \mathrm{h}$. Embora o arrefecimento a ar seja de montagem mais simples e, portanto, mais barato, justifica-se a adoção do arrefecimento a água em virtude do binômio melhor rendimento e baixo consumo elétrico.

Independentemente do sistema de arrefecimento, notaram-se irregularidades na curva de queda de temperatura da massa de ar no interior da gincana, queda esta que não foi linear. Nos pontos posteriores às curvas da gincana, havia um ganho de temperatura pela massa de ar. Este fenômeno poderia ser atribuído ao maior atrito entre a massa de ar e as paredes da gincana. Embora tenha sido irrelevante para os ensaios efetuados, este fato poderia significar diminuição significativa de rendimento em sistemas de maiores vazões. Optou-se pela montagem em gincana visando a otimização do espaço em eventuais modelos comerciais, idéia desde já abandonada. Para o prosseguimento dos trabalhos, a nível experimental, foi o adotado o formato linear do condicionador. Não foi efetuado o cálculo de rendimento na conformação linear de condicionador em virtude de que sua utilização comercial é inviável.

Com referência a eventuais módulos comerciais, os resultados apontam para a necessidade de trocas térmicas a água, com recirculação. Dessa forma, para uma operação em regime de refrigeração do ar, o calor absorvido pela água de arrefecimento seria rejeitado em um dispositivo semelhante a um radiador, com circulação por bomba d'água. No ciclo inverso (aquecimento do ar), o calor seria absorvido da água e rejeitado para a massa de ar a ser aquecida. O uso comercial da TT exige, também que os módulos sejam suficientemente compactos, o que 
poderia ser conseguido com a montagem de seqüências paralelas de módulos de condicionamento, dispostas em um ou mais planos distintos, na dependência das vazões envolvidas. Desta forma, não existe limite máximo para o número de módulos de condicionamento a serem utilizados em conjunto.

Uma prática comum em tecnologia de condicionamento de ar constitui-se na simulação matemática de operação de sistemas. Da mesma forma, a maioria dos sistemas convencionais de condicionamento opera com mistura de ar, ou seja, mistura-se a massa de ar condicionado, de recirculação, com determinada massa de ar externo, não condicionado e o resultado da mistura é insuflado no ambiente. Este procedimento é válido para instalações de conforto humano, não podendo ser adotado em biotérios em virtude do aumento exponencial dos níveis de vapor de amônia. Por outro lado, para biotérios, pode-se adotar o procedimento de mistura de ar condicionado ao ar não condicionado desde que se efetue o expurgo completo da mistura. As simulações matemáticas efetuadas basearam-se neste procedimento e revelaram a capacidade para condicionamento de, respectivamente, $\cong 91$ e 137 padrão para ratos, em arrefecimento a ar e a água.

Neste ponto, é importante citar, novamente, a característica de facilitador do mecanismo de convecção forçada dos sistemas microambientais. Para as simulações efetuadas, foram assumidos valores de $30^{\circ} \mathrm{C}$ para TempE e $22^{\circ} \mathrm{C}$ para TempF. Na dependência da velocidade do ar aplicada ao sistema, o nível de $22^{\circ} \mathrm{C}$ para TempF poderia ser extremamente desconfortável para os animais. Isso significa que em tais sistemas pode-se trabalhar com faixas de temperatura mais elevadas, portanto menores diferenças entre TempE e TempF, o que, na prática significa que, para uma vazão e temperatura de ar condicionado constantes, pode-se aumentar a porcentagem de ar não condicionado da mistura ou utilizar um número menor de unidades termoelétricas. Importante ressaltar que, independente da solução adotada, o resultado tenderá sempre à diminuição dos custos.

Com relação a custos, considera-se válida a comparação efetuada no presente trabalho por se tratarem de custos recentes. Além disso, a comparação em termos de custo de implantação por BTU gerado nos sistemas permitiu que fossem desprezadas grandezas como vazões e área beneficiada. Em termos de implantação, observou-se que o sistema operando com tecnologia termoelétrica (SOTT) permite uma redução de $\cong 26 \%$, que é considerada significativa, embora passível de algumas considerações: i. o sistema de compressão do freon utilizado 
para comparação foi instalado por uma empresa, por meio de processo de concorrência pública; ii. incide no valor de custo desta instalação impostos que não foram computados no caso do SOTT; iii. o SOTT foi montado no LAMBDA para ensaios de bancada; iv. não foi computado o custo de mão de obra na montagem do SOTT. Mesmo assim, consideram-se relevantes estes resultados em virtude da simplicidade da montagem do SOTT e da baixa necessidade de manutenção em virtude da pequena quantidade de peças móveis. Experimentos posteriores deverão ser realizados visando a comparação de custos de manutenção dos dois sistemas. Os resultados também apontam para uma redução de consumo elétrico de $\cong 32 \%$ por BTU gerado pelo SOTT com arrefecimento a água, quando comparado com o sistema de compressão do freon. Isto poderia ser explicado pelo funcionamento dos dois sistemas. No ciclo de freon, a energia elétrica é primeiramente convertida para energia mecânica (compressor) para depois ser convertida em trabalho frigorígeno efetivo, ao passo que o SOTT transforma diretamente energia elétrica em trabalho frigorígeno. Entretanto, acredita-se que, da mesma forma que os custos com manutenção dos dois sistemas, trabalhos posteriores devam ser realizados para o refinamento deste resultado.

Outras duas características do SOTT devem ser ressaltadas. Uma delas é a precisão da faixa de temperatura mantida. O sistema montado operou com variação de $\pm 0,1^{\circ} \mathrm{C}$, o que é impossível de ser obtido em sistemas convencionais de compressão de freon. Isso possibilita um extremo refinamento em experimentos nos quais a exatidão da temperatura seja fator primordial, como por exemplo em câmaras climáticas. A segunda é a reversibilidade do fenômeno termoelétrico, o que na prática significa que a massa de ar pode ser resfriada ou aquecida pelo mesmo sistema, apenas com inversão do sentido da corrente elétrica de alimentação dos módulos Peltier. Este fato também é impossível num sistema de compressão de freon de grande porte. Nos sistemas de pequeno porte, até 60.000 BTU's, isso é feito com a inversão do fluxo de freon, quando o evaporador passa a funcionar como condensador e vice-versa. Os ciclos de grande porte envolvem compressores de grande potência, maior atrito e maior geração de calor, o que exigiria condensadores muito grandes, em relação às unidades evaporadoras o que torna elétrica e termodinamicamente inviável a inversão do ciclo. Sistemas de compressão de freon de grande porte possuem uma resistência elétrica exclusiva para o aquecimento da massa de ar para os animais, em situações de baixa temperatura externa. 
A segunda parte do trabalho foi realizada justamente com intuito de avaliar a conversão metabólica, ingestão de ração/ganho de peso de ratos, em uma câmara climática equipada com TT portanto, com temperaturas experimentais constantes e praticamente exatas (Tabelas 5 a 11).

Foram notadas diferenças estatisticamente significantes na quantidade de ração ingerida entre os grupos (Tabela 12 e Figura 39), o grupo C I (22 $\left.\pm 2^{\circ} \mathrm{C}\right)$ ingeriu mais ração que o grupo $\mathrm{E}$ III $\left(26 \pm 0.1^{\circ} \mathrm{C}\right)$ e $\mathrm{E} \mathrm{V}\left(30 \pm 0,1^{\circ} \mathrm{C}\right)$. O Grupo E I (22 $\left.\pm 0,1^{\circ} \mathrm{C}\right)$ ingeriu mais ração que $\mathrm{E} V\left(30 \pm 0.1^{\circ} \mathrm{C}\right)$ e o grupo $\mathrm{E} / \mathrm{l}\left(24 \pm 0,1^{\circ} \mathrm{C}\right)$ mais ração que o grupo $\mathrm{E}$ III $\left(26 \pm 0,1^{\circ} \mathrm{C}\right)$ e $\mathrm{E} \mathrm{V}\left(30 \pm 0,1^{\circ} \mathrm{C}\right)$. Pode-se deduzir que com o aumento da temperatura, os animais tendem a ingerir menos ração devido ao menor consumo calórico para a manutenção do seu metabolismo.

Tendo em vista que o grupo controle C I foi mantido sob condições convencionais de condicionamento térmico, compreendido como o ambiente do laboratório, no qual o experimento foi conduzido, $22 \pm 2{ }^{\circ} \mathrm{C}$, foi necessária a repetição das condições do grupo controle (C II), agora, porém, no interior da CIT, sem direcionamento de ar sobre os animais, simulando-se uma condição de ventilação geral diluidora, na qual se poderia obter um ambiente com temperatura de $22 \pm$ $0,1^{\circ} \mathrm{C}$.

Quando os grupos foram comparados estatisticamente (Tabela 13 e Figura 40), o ganho de peso do grupo C I $\left(22 \pm 2^{\circ} \mathrm{C}\right)$ foi maior que o dos grupos $\mathrm{E}$ I $\left(22 \pm 0,1^{\circ} \mathrm{C}\right)$ e $\mathrm{E} \| \mathrm{I}\left(24 \pm 0,1^{\circ} \mathrm{C}\right)$. O grupo $\mathrm{C} \| \mathrm{I}\left(22 \pm 0,1^{\circ} \mathrm{C}\right)$ ganhou mais peso que os grupos $\mathrm{E}$ I, E II, E III $\left(26 \pm 0,1^{\circ} \mathrm{C}\right)$ e E IV $\left(28 \pm 0,1^{\circ} \mathrm{C}\right)$. O grupo $\mathrm{E}$ I teve um aumento de peso menor que $\mathrm{E}$ II, E III, E IV e E V $\left(30 \pm 0,1^{\circ} \mathrm{C}\right)$. O grupo $\mathrm{E}$ II ganhou menos peso que $E$ IV e $E$ V e o grupo $E$ III ganhou menos peso que $E$ V. Estes dados mostram claramente que quanto maior a temperatura do fluxo de ar, direcionado para os animais, maior o ganho de peso dos grupos. Este aumento do ganho de peso tende a se igualar aos grupos controle na faixa de 28 a $30^{\circ} \mathrm{C}$.

Ficou evidente uma relação linear direta entre o ganho de peso e o aumento da temperatura a que os diferentes grupos foram submetidos. Isto indica maior conversão da ração ingerida para a massa corpórea em temperaturas mais elevadas e maior conversão para energia em temperaturas mais baixas, o que poderia ser explicado pela necessidade da manutenção de homeostasia do animal. 
Em temperaturas mais baixas de ar e aplicando-se a ele uma certa velocidade, a sensação térmica de maior frio se intensifica.

Os fatos comentados levam a questionar fortemente a literatura sobre condicionamento de ar para biotérios produzida até o momento. Sob condições de ventilação microambiental, existe uma forte influência do fator "convecção forçada" sobre os animais. Tal fenômeno permite que se obtenha, nestes, sensação térmica de conforto com temperaturas de ar maiores do que as citadas pela literatura mundial para sistemas convencionais. Mesmo sem qualquer rebaixamento da temperatura de bulbo seco de determinada massa de ar, somente o deslocamento dessa massa sobre um organismo (convecção forçada), já é capaz de remover energia térmica, provocando uma sensação de resfriamento que poderá chegar até o desconforto na dependência da velocidade dessa massa de ar, da umidade presente e, obviamente, da temperatura dessa massa de ar.

Com relação ao conforto humano, esse assunto já foi suficientemente abordado, existindo, inclusive, diversos tipos de cartas de conforto térmico, as quais podem facilmente ser consultadas pelos técnicos para projetos de sistemas de condicionamento de ar. Com relação a animais, em especial os roedores de laboratório, estudos deste tipo merecem ainda muita demanda em trabalhos experimentais que levem em consideração as diferentes espécies, bem como as distintas condições fisiológicas.

Os grupos experimentais mantidos sob diferentes temperaturas mostraram umidade mais baixa nas sobras de ração, quando comparada ao grupo controle. Fato semelhante foi observado por Caríssimi et al. (2000) com relação à maravalha em sistemas microambientais. Os autores comentam que a constante passagem de ar sobre os animais e conseqüentemente sobre a maravalha diminui drasticamente o teor de umidade desta o que poderia contribuir para a menor geração de vapores de amônia, o que pode ser observado também neste trabalho na tabela 14.

Visto que pode-se considerar viável a TT para controle térmico de biotérios, associada a sistemas VMA, torna-se necessária a avaliação do binômio velocidade/temperatura do ar para todas as espécies convencionais, em diferentes condições fisiológicas, o que não foi escopo do presente trabalho. Um estudo acerca deste tema encontra-se em fase inicial no $L A M B D A$, tendo por base 0 comportamento de escolha em ratos submetidos a diferentes opções de clima. Quando concluído, este estudo permitirá ao projetista a determinação exata das 
condições de conforto para cada espécie em suas diferentes necessidades. A TT, associada à tecnologia MFPIV e à informática permitirá ainda, que em um mesmo módulo de estante ventilada, cada microisolador apresente uma condição termohigrométrica e de velocidade de ar específica, independentemente dos demais.

A ciência de animais de laboratório tem um viés extremamente prático no sentido de se aproximar muito a uma linha de produção industrial. Nesse sentido, buscou-se o desenvolvimento de um equipamento com potencial para ser competitivo no mercado. Acredita-se realmente nesse potencial visto a grande quantidade de estantes ventiladas existentes em funcionamento, eventuais equipamentos que podem ser utilizados em conjunto com sistema de tratamento termohigrométrico ora apresentado. Até o presente momento, o processo de obtenção de patente do equipamento descrito neste trabalho encontra-se em tramitação junto aos órgãos competentes da Universidade de São Paulo, o que por certo, agilizará o repasse desta tecnologia à sociedade. 


\section{CONCLUSÕES}


Os resultados do presente trabalho permitem concluir que:

1. A tecnologia termoelétrica é viável para controle térmico de biotérios, quando em conjunto com a tecnologia VMA;

2. O arrefecimento a água dos módulos termoelétricos tendem a aumentar seu rendimento, sendo o sugerido para futuros condicionadores comerciais por TT para biotérios;

3. Ratos mantidos a $30^{\circ} \mathrm{C}$ sob velocidade de ar de $0,6 \mathrm{~m} / \mathrm{s}$ mostraram a mesma conversão ração ingerida/massa corpórea que os animais do grupo controle, mantidos a $22^{\circ} \mathrm{C}$ e velocidade de ar padrão VGD para biotérios $(\cong 0 \mathrm{~m} / \mathrm{s})$;

4. Embora ainda necessitando de maiores detalhamentos experimentais, os resultados obtidos até o presente momento, em especial quanto ao binômio temperatura/velocidade de ar em tecnologia VMA, apontam uma faixa de temperatura ideal para animais, diferente da preconizada atualmente para sistemas de VGD;

5. As tecnologias termoelétrica e VMA poderão, em breve, ser adotadas como padrão para controle atmosférico de biotérios. 
REFERÊNCIAS 
ACGIH. American Conference of Governmental Industrial Hygieninsts. Industrial ventilation - a manual of recommended practice. $22^{\text {nd }}$ ed. Ohio: ACGIH, 1995.

BARBOSA, J. A. R. Estudo sobre a influência dos intervalos de trocas de cama na manutenção de ratos (Rattus norvegicus) acasalados em sistema de ventilação microambiental. 1999. 74 f. Dissertação (Mestrado em Patologia Experimental e Comparada) - Faculdade de Medicina Veterinária e Zootecnia, Universidade de São Paulo, São Paulo, 1999.

BAUMANS, V.; SCHLINGMANN, F.; VONCK, M.; VAN LITH, H. A. Individually Ventilated Cages: Beneficial for Mice and Men? Contemporary Topics In aboratory Animals Science. Estados Unidos da América, v. 40, n. 5, p. 25-30, 2001.

BESCH, E. L. Definition of laboratory animal environmental conditions. In: MOBERG, G. P. Animal stress. Bethesda: American Phisiological Society, 1985. p. 297-315.

BEYER, P. O. Curso de psicrometria. São Paulo: ASBRAV, 1983. p. 1-39.

CARISSIMI, A. S.; CHAGURI, L. C.; TEIXEIRA, M. A.; MORI, C. M. C.; MACCHIONE, M.; SANT'ANNA, E. T. G.; SALDIVA, P. H. N.; SOUZA, N. L.; MERUSSE, J. L. B. Effects of two ventilation systems and bedding change frequency on cage environmental factors in rats (Rattus norvegicus). Animal Technology, Inglaterra, v. 51, n. 3, p. 161-170, 2000.

CCAC. CANADIAN COUNCIL ON ANIMAL CARE. Guide to the care and use of experimental animals. Ontário: CCAC, 1980. v.1, p. 15-22.

CHAGURI, L. C. A. G.; SOUZA, N. L.; TEIXEIRA, M. A.; CARISSIMI, A. S.; MERUSSE, J. L. B. Evaluation of reproductive indices in rats (Rattus norvergicus) housed under an intracage ventilation system. Contemporary Topics In Laboratory Animals Science, Estados Unidos da América, v. 40, n. 5, p. 25-30, 2001.

COSTA, Ê. C. Refrigeração. São Paulo: Edgard Blucher, 1982. p. 215-221. 
DELGADO, M. O.; TIMENETSKI, J. Immunoblot profiles of sera from laboratory rats naturally infected with mycoplams pulmonis and technicians exposed to infected animal facilities. Brazilian Journal of Microbiology, v. 32, p. 301-304, 2001.

EFEITO Peltier. In: ENSINO DE FÍSICA ON-LINE. 2007a. Disponível em: <http://efisica.if.usp.br/eletricidade/basico/termo/efeito_peltier/>. Acesso em: 28 jun. 2007.

EFEITO Peltier. In: WIKIPÉDIA, a enciclopédia livre. 2007b. Disponível em: <http://pt.wikipedia.org/wiki /Efeito_Peltier>. Acesso em: 28 jun. 2007.

EFEITO Seebeck. In: WIKIPÉDIA, a enciclopédia livre. 2006. Disponível em: <http://pt.wikipedia.org/wiki/Efeito_Seebeck>. Acesso em: 28 jun. 2007.

EFEITO Termoelétrico ou Efeito Seebeck. In: ENSINO DE FÍSICA ON-LINE. 2007c. Disponível em:

<http://efisica.if.usp.br/eletricidade/basico/termo/efeito_termoeletrico/>. Acesso em: 28 jun. 2007.

ENTALPIA. In: WIKIPÉDIA, a enciclopédia livre. 2007. Disponível em: <http://pt.wikipedia.org/wiki/Entalpia>. Acesso em: 28 jun. 2007.

FONTES, R. S. Estudo da influência ambiental no estado sanitário e nas respostas a testes comportamentais de ratos (Rattus norvegicus) mantidos em dois diferentes sistemas de ventilação para biotérios. 1999. 48 f. Monografia (Trabalho de conclusão de curso) - Centro Estadual de Educação Tecnológica Paula Souza - Faculdade de Tecnologia de Sorocaba, Sorocaba, 1999.

FRANCIS, G. L. General hazards. In: SEAMER. J. H.; WOOD, M. Safety in the animal house. 2. ed. London: Laboratory Animals, 1981. p. 1-10.

GAMBLE, M. R.; CLOUGH, G. Ammonia build-up in animal boxes and its effect on rat tracheal epithelium. Laboratory Animals, v. 10, p. 93-104, 1976. 
HOLMAN J. P. Transferência de calor. São Paulo: MacGraw-Hill do Brasil, 1983. p. 1-24.

HUNSKAAR, S.; FOSSE, R. T. Allergy to laboratory mice and rats: a review of the patophysiology, epidemiology and clinical aspects. Laboratory Animals, v. 24, n. 4, p. 358-374, 1990.

MACINTYRE, A. J. Ventilação industrial e controle da poluição. Rio de Janeiro: Guanabara, 1990. p. 1-3; 26-36; 92-104.

MARTINEWSKI, A. Sistema de ventilação microambiental utilizando caixas pressurizadas e intraventiladas por microventiladores de corrente contínua: desempenho físico do sistema e resultados de ensaios biológicos em camundongos BALB/c padrão SPF. 2001. 114 f. Dissertação (mestrado em Patologia) - Faculdade de Medicina Veterinária e Zootecnia, Universidade de São Paulo, São Paulo, 2001.

MERUSSE, J. L. B. Equipamento para criação e manutenção de animais utilizados em experimentação biomédica e respectivo processo de distribuição unidirecional do ar. Revista de Propriedade Industrial, n.1262, p. 28, 1995.

MURAKAMI, H. Differences between internal and external environments of the mouse cage. Laboratory Animal Science, v. 21, n. 5, p. 680-684, 1971.

OPAS: ORGANIZACION PANAMERICANA DE LA SALUD. Animales de laboratório. Guia para instalaciones y cuidado de animales de laboratório. Washington: OPAS, 1968. p. 1-54.

OSWEILLER, G. D.; CARSON, T. L.; BUCK, W. B.; VAN GLEDER, G. A. Clinical and diagnostic veterinary toxicology. 3. ed. Dubuque: Kendall/Hunt, 1985. p. 369377.

PELEGRINI, M. Manual compacto de física: teoria e prática. São Paulo: Rideel, 1997. p. 141-167.

ROWE, D. M. CRC handbook of thermoelectrics. Washington, D.C.: CRC, 1994. p. $7-41 ; 211-238$. 
SERRANO, L. J. Carbon dioxide and ammonia in mouse cages: effect of cage covers, population and activity. Laboratory Animal Science, v. 21, n. 1, p. 75-85, 1971.

SLAS: SOCIETY FOR LABORATORY ANIMAL SCIENCE. Committe on training and correct housing of laboratory animals. On the planning and structure of animal facilities for institues performing animal experiments. 2. ed. Basel: SLAS, 1989. p. $39-48$.

TARGOWSKI, S. P.; KLUCISKI, W; BABIKER, S.; NONNECKE, B. J. Effect of ammonia on in vivo and in vitro immune responses. Infection and Immunity, v. 43, n. 1, p. 289-293, 1984.

TEIXEIRA, M. A.; CHAGURI, L. G.; CARISSIMI, A. S.; SOUZA, N. L.; MORI, C. M. C.; GOMES, V. M. W.; POLI NETO, A.; NONOYAMA, K.; MERUSSE, J. L. B. Hematological and biochemical profiles of rats (Rattus norvegicus) kept under microenvironmental ventilation system. Brazilian Journal of Veterinary Research and Animal Science, v. 37, n. 5, p. 342-347, 2000.

TEIXEIRA, M. A.; SALDIVA, P. H. N.; SOUZA, N. L.; SINHORINI, I. L.; MERUSSE, J. L. B. Reduction of atmospheric ammonia $(\mathrm{NH} 3)$ and incidence of pulmonary lesions in mice kept in plenum chamber microenvironmental ventilation system.

Scandinavian Journal Of Laboratory Animals Science, Noruega, v. 28, n. 3, p. 145-153, 2001a.

TEIXEIRA, M. A.; SINHORINI, I. L.; SOUZA, N. L.; MERUSSE, J. L. B. Microenvironmental ventilation system for laboratory animal facilities with air distribution by means of plennum chambers. Animal Technology, Inglaterra, v. 50, n. 3, p. 187-194, 1999.

TEIXEIRA, M. A.; SOUZA, N. L.; MERUSSE, J. L. B. Mice productivity in a microenvironmental ventilation system using plennum chambers. Animal Technology, Inglaterra, v. 52, n. 3, p. 233-242, 2001b.

YAMANE E.; SAITO H. Tecnologia do condicionamento de ar. São Paulo: Edgard Blucher, 1986. p. 8-27.

ZHANG, Y. A survey of laboratory rat environment. ASHRAE TRANS. SYMPOSIA, v. 98, parte 2, p. 247-343, 1992. 
ANEXOS 


\section{ANEXO A - SISTEMA INTERNACIONAL DE UNIDADES}

\begin{tabular}{|c|c|}
\hline LQES & LQES INDEX \\
\hline & Sistema SI: Unidades, Símbolos e Prefixos \\
\hline & Editoria do LQES Website \\
\hline
\end{tabular}

\section{Sistema Internacional de Unidades - SI}

As informações aqui apresentadas irão ajudar você a compreender melhor e a escrever corretamente as unidades de medidas adotadas no Brasil. A necessidade de medir é muito antiga e remota à origem das civilizações. Por longo tempo, cada país, cada região, teve o seu próprio sistema de medidas baseadas em unidades arbritárias e imprecisas como, por exemplo, aquelas baseadas no corpo humano: palmo, pé, polegada, braça, côvado.

Isso criava muitos problemas para o comércio, porque as pessoas de uma região não estavam familiarizadas com o sistema de medida das outras regiões. Imagine a dificuldade em comprar ou vender produtos cujas quantidades eram expressas em unidades de medidas diferentes e que não tinham correspondência entre si.

Em 1789, numa tentativa de resolver o problema, o Governo Republicano Francês pediu à Academia de Ciências da França que criasse um sistema de medidas baseado numa "constante natural". Assim foi criado o Sistema Métrico Decimal. Posteriormente, muitos outros países adotaram o sistema, inclusive o Brasil, aderindo à "Convenção do Metro". O Sistema Métrico Decimal adotou, inicialmente, três unidades básicas de medida: o metro, o litro e o quilograma.

Entretanto, o desenvolvimento científico e tecnológico passou a exigir medições cada vez mais precisas e diversificadas. Por isso, em 1960, o sistema métrico decimal foi substituído pelo Sistema Internacional de Unidades - SI, mais complexo e sofisticado, adotado também pelo Brasil em 1962 e ratificado pela Resolução no 12 de 1988 do Conselho Nacional de Metrologia, Normalização e Qualidade Industrial - Conmetro, tornando-se de uso obrigatório em todo o Território Nacional. A Tabela 1 apresenta as principais grandezas e as medidas e unidades adotadas pelo sistema SI.

As unidades SI são grandes quando comparadas às quantidades que são convenientes para a química e as profissões da saúde. De fato as quantidades usadas estão indo à direção de valores cada vez menores dado ao desafio de se trabalhar com quantidades cada vez mais em microescala. 
Tabela 1. Grandezas, Nomes e Símbolos do Sistema Internacional de Unidades

\begin{tabular}{|c|c|c|c|}
\hline Grandeza & Nome & Plural & Símbolo \\
\hline comprimento & metro & metros & m \\
\hline área & metro quadrado & metros quadrados & $\mathrm{m}^{2}$ \\
\hline volume & metro cúbico & metros cúbicos & $\mathbf{m}^{3}$ \\
\hline ângulo plano & radiano & radianos & rad \\
\hline tempo & segundo & segundos & $\mathbf{s}$ \\
\hline freqüência & hertz & hertz & $\mathrm{Hz}$ \\
\hline velocidade & metro por segundo & metros por segundo & $\mathrm{m} / \mathrm{s}$ \\
\hline aceleração & $\begin{array}{c}\text { metro por segundo por } \\
\text { segundo }\end{array}$ & $\begin{array}{c}\text { metros por segundo por } \\
\text { segundo }\end{array}$ & $\mathrm{m} / \mathrm{s}^{2}$ \\
\hline massa & quilograma & quilogramas & kg \\
\hline massa específica & quilograma por metro cúbico & $\begin{array}{c}\text { quilogramas por metro } \\
\text { cúbico }\end{array}$ & $\mathrm{kg} / \mathrm{m}^{3}$ \\
\hline vazão & metro cúbico por segundo & $\begin{array}{l}\text { metros cúbicos por } \\
\text { segundo }\end{array}$ & $\mathrm{m}^{3} / \mathrm{s}$ \\
\hline quantidade de matéria & mol & mols & mol \\
\hline força & newton & newtons & $\mathbf{N}$ \\
\hline pressão & pascal & pascals & $\mathbf{P a}$ \\
\hline $\begin{array}{l}\text { trabalho, energia } \\
\text { quantidade de calor }\end{array}$ & joule & joules & J \\
\hline potência, fluxo de energia & watt & watts & W \\
\hline corrente elétrica & ampère & ampères & A \\
\hline carga elétrica & coulomb & coulombs & C \\
\hline tensão elétrica & volt & volts & V \\
\hline resistência elétrica & ohm & ohms & $\Omega$ \\
\hline condutância & siemens & siemens & $\mathbf{S}$ \\
\hline capacitância & farad & farads & $\mathbf{F}$ \\
\hline temperatura Celsius & grau Celsius & graus Celsius & ${ }^{\circ} \mathrm{C}$ \\
\hline temp. termodinâmica & kelvin & kelvins & $\mathbf{K}$ \\
\hline intensidade Iuminosa & candela & candelas & cd \\
\hline fluxo luminoso & lúmen & lúmens & Im \\
\hline iluminação & lux & lux & Ix \\
\hline
\end{tabular}




\section{Prefixos}

O sistema SI (International System) permite que as grandezas das unidades possam ser expressas como as maiores ou menores através do uso apropriado de prefixos. Por exemplo, a unidade elétrica um Watt não é uma unidade enorme se consideramos os usos comuns de uma residência, entretanto, é normalmente usada em termos de 1000 Watts. O prefixo para 1000 é kilo de modo que usamos kilowatts (kW) como nossa unidade de medida. Para os produtores de eletricidade (hidrelétricas) ou grandes consumidores de eletricidade como as indústrias, é comum o uso de megawatts (MW) ou mesmo gigawatts (GW).

A grande quantidade de prefixos com os seus respectivos símbolos e abreviaturas e seus fatores de multiplicação são apresentados na Tabela 2.

Tabela 2. Prefixos do Sistema Internacional de Medidas

\begin{tabular}{|c|c|c|c|}
\hline yotta & {$[\mathbf{Y}]$} & 1000000000000000000000000 & $10^{24}$ \\
\hline zetta & {$[\mathbf{Z}]$} & 1000000000000000000000 & $10^{21}$ \\
\hline exa & [E] & 1000000000000000000 & $10^{18}$ \\
\hline peta & {$[\mathbf{P}]$} & 1000000000000000 & $10^{15}$ \\
\hline tera & {$[\mathrm{T}]$} & 1000000000000 & $10^{12}$ \\
\hline giga & [G] & 1000000000 & $10^{9}$ \\
\hline mega & [M] & 1000000 & $10^{6}$ \\
\hline kilo & [k] & 1000 & $10^{3}$ \\
\hline hecto & [h] & 100 & $10^{2}$ \\
\hline deca & [da] & 10 & 10 \\
\hline & & 1 & \\
\hline deci & [d] & 0,1 & $10^{-1}$ \\
\hline centi & [c] & 0.01 & $10^{-2}$ \\
\hline mili & {$[\mathrm{m}]$} & 0,001 & $10^{-3}$ \\
\hline micro & {$[\mu]$} & 0,000001 & $10^{-6}$ \\
\hline nano & [n] & 0,000000001 & $10^{-9}$ \\
\hline pico & [p] & 0,000000000001 & $10^{-12}$ \\
\hline femto & [f] & 0,000000000000001 & $10^{-15}$ \\
\hline atto & [a] & 0,000000000000000001 & $10^{-18}$ \\
\hline zepto & [z] & 0,000000000000000000001 & $10^{-21}$ \\
\hline yocto & [y] & 0,000000000000000000000001 & $10^{-24}$ \\
\hline
\end{tabular}

Todos os prefixos do SI são múltiplos (kilo a yotta) ou sub-múltiplos (mili a yocto) de 1000. 


\section{BIBLIOGRAFIA}

[1] Instituto Nacional de Metrologia, Normalização e Qualidade Industrial Inmetro. http://www.inmetro.gov.br/inmetro/oque.asp 


\section{ANEXO B - DADOS TÉCNICOS DO MÓDULO TERMOELÉTRICO}

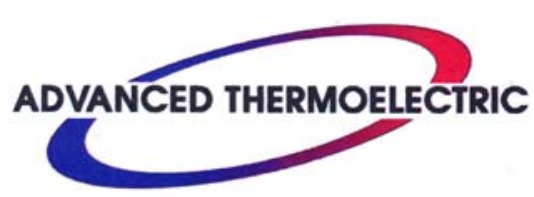

Technical Data Sheet

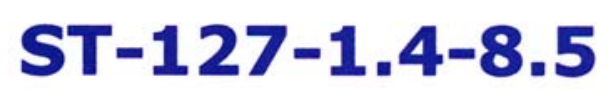

Standard Series Thermoelectric Module

\begin{tabular}{|c|c|}
\hline UNIT CODE & DESCRIPTION \\
\hline ST-127-1.4-8.5 & Thermoelectric Cooling Module \\
\hline
\end{tabular}

\begin{tabular}{|c|c|c|c|}
\hline \multicolumn{4}{|c|}{ SPECIFICATIONS } \\
\hline $\begin{array}{c}\text { Current } \\
\mathbf{I}_{\max }\end{array}$ & $\begin{array}{c}\text { Voltage } \\
\mathbf{V}_{\max }\end{array}$ & $\begin{array}{c}\text { Cooling Capacity } \\
\mathbf{Q}_{\max }\end{array}$ & $\begin{array}{c}\text { Maximum Delta } \mathrm{T} \\
\Delta \mathbf{T}_{\max }\end{array}$ \\
\hline $\mathbf{8 . 5}$ Amps & $\mathbf{1 7 . 5}$ Volts & $\mathbf{8 0}$ Watts & $\mathbf{7 0}^{\circ} \mathbf{C}$ \\
\hline
\end{tabular}

\section{PERFORMANCE CURVES $\left(T_{h}=25^{\circ} \mathrm{C}\right)$}
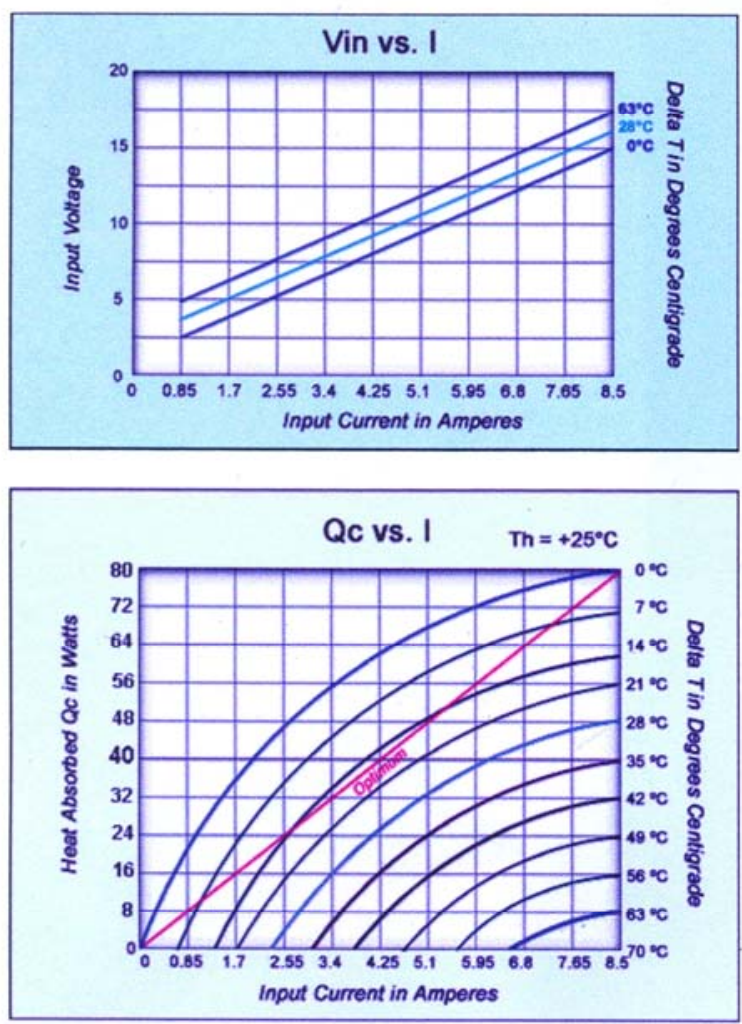

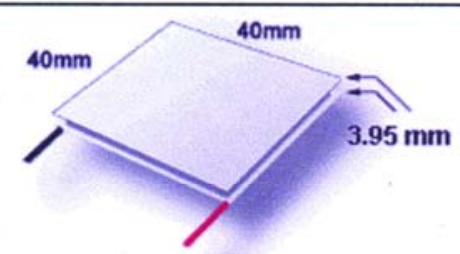

ST-127-1.4-8.5 is our most powerful single-stage thermoelectric module, in the $40 \times 40 \mathrm{~mm}$ footprint, intended for use with 12 to 15 -volt DC power sources. Having the greatest Qmax also means having to eject the greatest amount of heat and this module may require a fabricated forced convection heat sink, or liquid heat sink, in order to limit the hot-side temperature increase to an acceptable level.

ST-127-1.4-8.5 may be used for cooling, heating and temperature stabilization and is employed in a wide range of applications including consumer, industrial, lab/scientific, biomedical, telecommunications, military and aerospace. Also available with porch, metallized and tinned surfaces and in strings from 2-12 modules long. A High Performance version is available and should be selected for thermal cycling.

$100 \%$ QC (C of C available by Lot)

Operating temperature $-50^{\circ} \mathrm{C}+150^{\circ} \mathrm{C}$

Height, flatness and parallel variance: $\pm 0.02 \mathrm{~mm}$

Option Suffix designations:

Anti-corrosion Potting $=$ "P"

Epoxy edge sealing = "E"

Lapping to $\pm 0.01 \mathrm{~mm}=$ "L"

(for examole ST-127-1.4-8.5"PE")

$Q_{\max }$ is the maximum amount of heat the module is capable of pumping. This value is achieved when there is no difference in the temperature $(D T=0)$ on the modules two surfaces. If your application requires cooling, the heat pumping capacity will be less.

$\Delta T_{\max }$ or $\mathrm{DT} T_{\max }$ is the maximum temperature differential between the hot and cold side of the module with no heat load $(Q=0)$. As the thermal mass of the object to be cooled increases the $\Delta T$ becomes fewer degrees until $Q_{\max }$ is reached and $\Delta T=0$. 
ANEXO C - DIAGRAMA PSICROMÉTRICO

CARTA PSICROMÉTRICA PARA UMA ALTITUDE DE 750 m ACIMA DO NÍVEL DO MAR

EM UNIDADES MÉTRICAS, SISTEMA INTERNACIONAL

$140 \quad 145$

\section{Pressão Barométrica $92.600 \mathrm{kPa}$}

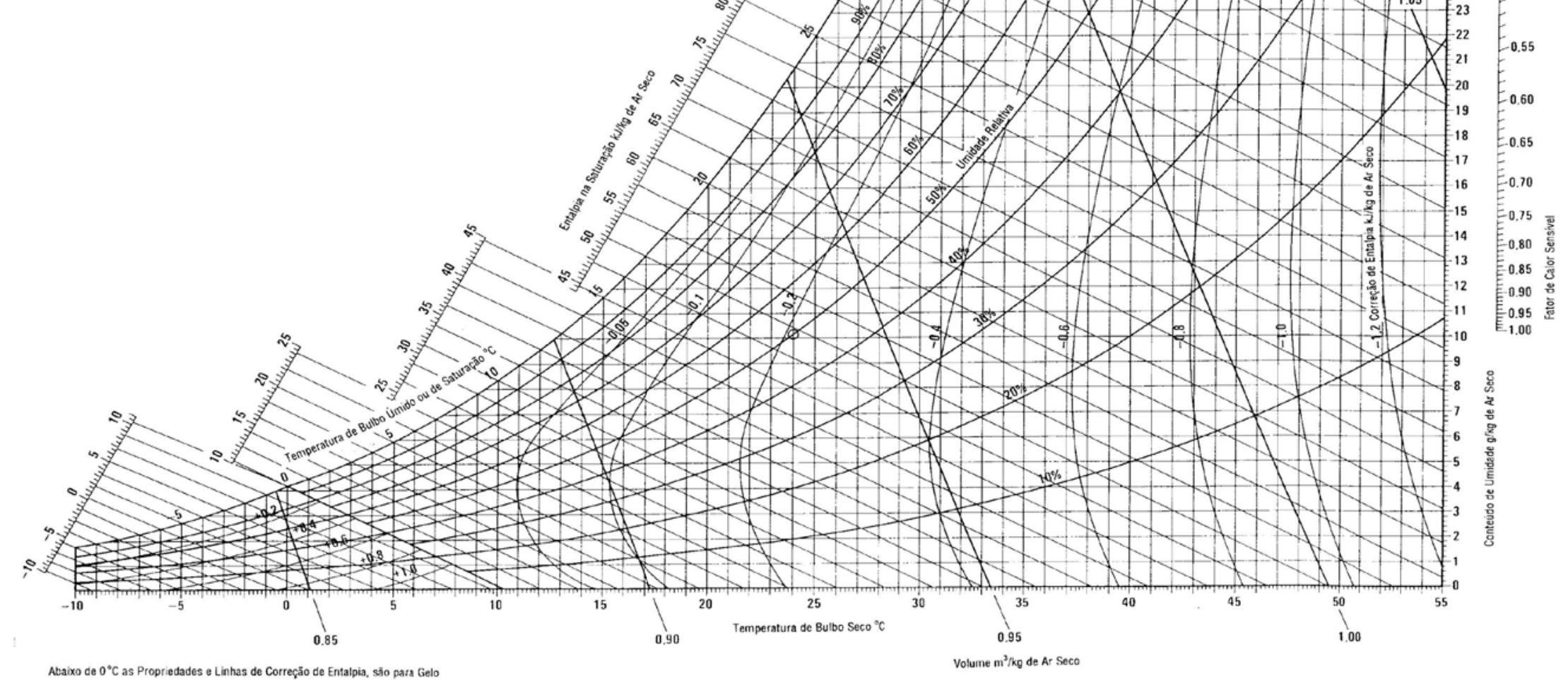

